\title{
Progressive Religion and Free Exercise Exemptions
}

\author{
Angela C. Carmella*
}

\section{INTRODUCTION}

Progressive religious causes have grown increasingly visible during the Trump presidency. ${ }^{1}$ Dr. Scott Warren, volunteering with a Unitarian ministry, is arrested for giving food and water to border crossers in Arizona and charged with felony harboring. ${ }^{2}$ Catholic nuns in Pennsylvania try to stop the installation of a natural gas pipeline across their land. ${ }^{3}$ Bishop Daniel Flores of the Diocese of Brownsville, Texas refuses to allow federal agents to build part of the border wall on church property. ${ }^{4}$ The Standing Rock Sioux and Cheyenne Tribes try to prevent the routing of an oil pipeline through sacred water in North Dakota. ${ }^{5}$ A

* (C) 2019 Angela C. Carmella. Professor of Law, Seton Hall University School of Law, Angela.Carmella@shu.edu. I am grateful to Michael Ambrosio, Thomas Berg, Robert Cochran, Paul Hauge, Christopher Lund, Catherine McCauliff, David Opderbeck, Najarian Peters, Melissa Rogers, Charles Sullivan, and Richard Winchester for comments on earlier drafts, and to Gabrielle Bamberski and Anne McCullough for their research assistance. I am also grateful to the Seton Hall Law School administration for summer research support. The views expressed here are solely my own.

1. See Tom Gjelten, Provoked by Trump, the Religious Left Is Finding Its Voice, NPR (Jan. 24, 2019, 5:04 AM), https://www.npr.org/2019/01/24/684435743/provoked-by-trump-the-religious-leftis-finding-its-voice [https://perma.cc/VQ9C-FGHJ] ("Religious voters on the left ... are finding a new determination to defend the values of their faith, as they understand them."); see also discussion infra Part IV.

2. Miriam Jordan, An Arizona Teacher Helped Migrants. Jurors Couldn't Decide If It Was a Crime., N.Y. TIMES (June 11, 2019), https://www.nytimes.com/2019/06/11/us/scott-warren-arizonadeaths.html [https://perma.cc/8GTC-7BDL]; see discussion infra notes 427-45 and accompanying text.

3. Eliza Griswold, The Renegade Nuns Who Took on a Pipeline, NEW YoRKER (Apr. 10, 2019), https://www.newyorker.com/news/on-religion/the-renegade-nuns-who-took-on-a-pipeline [https://perma.cc/VB2V-35ZZ].

4. Bernadette Mary Reis, Diocese in Texas Prepares to Protect Its Land, VATICAN News (Nov. 5, 2018, 6:34 PM), https://www.vaticannews.va/en/church/news/2018-11/brownsville-texasdaniel-flores-survey-right-wall-federal-court.html [https://perma.cc/39UQ-QZ4F]; see discussion infra notes 390-410 and accompanying text.

5. Stephanie Keith, Out of the Spotlight, Tribes Keep Fighting Dakota Pipeline, ReUTERS (Aug. 2, 2018, 6:41 AM), https://www.reuters.com/article/us-south-dakota-native-americans/out-ofspotlight-tribes-keep-fighting-dakota-pipeline-idUSKBN1KN1HT [https://perma.cc/NCC8-KR9C]; see discussion infra notes $473-500$ and accompanying text. 
thousand churches offer sanctuary to the undocumented, ${ }^{6}$ and countless churches shelter the homeless and feed the poor, sometimes in violation of local ordinances. ${ }^{7}$ The Plowshares Seven are convicted of trespassing on a naval base for a religious protest of nuclear weapons. ${ }^{8}$ A thousand congregations install solar panels to be good stewards of God's creation. ${ }^{9}$ A bishop escorts asylum-seekers across the border in protest of federal policies. ${ }^{10}$ Religious communities of all sorts champion efforts to protect religious, racial, and other underrepresented groups. In many of these situations, religious people and entities exercising their faith come into conflict with law. They typically seek the remedy of a religious exemption.

Perhaps these examples seem surprising, as they involve conflicts between legal regimes and religious people committed to addressing issues of poverty, immigration, war, climate change, and the like. Over the last few decades we have grown accustomed to identifying religious freedom claims with conservative causes, ${ }^{11}$ like employers refusing to provide employee insurance coverage for contraceptives, ${ }^{12}$ a baker refusing to make a wedding cake for a same-sex couple, ${ }^{13}$ a churchaffiliated adoption service refusing to place a child with a same-sex couple, ${ }^{14}$ and religiously affiliated hospitals refusing to provide gender

6. Duarte Geraldino \& Frank Carlson, More Churches Are Opening Their Doors to Undocumented Immigrants Facing Deportation (Jan. 15, 2018, 6:30 PM), https://www.pbs.org/news hour/show/more-churches-are-opening-their-doors-to-undocumented-immigrants-facing-deportation [https://perma.cc/EJA9-BS2R].

7. See, e.g., Jonathan M. Pitts, Dundalk Church Faces Fine for Hosting Homeless, BALt. SuN (Dec. 12, 2016, 9:39 PM), https://www.baltimoresun.com/maryland/baltimore-county/bs-mdchurch-homeless-fine-20161212-story.html [https://perma.cc/4GQR-D94K].

8. Jesse Remedios, Kings Bay Plowshares Activists Found Guilty of All Charges, NAT'L CATH. REP. (Oct. 25, 2019), https://www.ncronline.org/news/people/kings-bay-plowshares-activistsfound-guilty-all-charges [https://perma.cc/C4X6-6US2].

9. Jeff Brumley, Churches Overcome Attitudes, and Sometimes the Law, to Go Solar, BAPTIST NEws GLOB. (Dec. 11, 2018), https://baptistnews.com/article/churches-overcome-attitudes-andsometimes-the-law-to-go-solar/ [https://perma.cc/FT6D-EYWU].

10. Shannon Mason, Texas Bishop Escorts Migrants Across the Border in Protest of U.S. Policy, N.Y. DAILY NEWS (June 28, 2019, 12:07 PM), https://www.nydailynews.com/news/national/ ny-texas-bishop-escorts-migrants-border-protest-20190628-g62a7k4iojbkbkaihi2urcyydi-story.html [https://perma.cc/P49Y-RC92].

11. See Christopher C. Lund, RFRA, State RFRAs, and Religious Minorities, 53 SAN DIEGO L. REV. 163, 164 (2016) (noting that high notoriety cases like "Hobby Lobby and Elane Photography... have become the face of free exercise to the general public").

12. See Burwell v. Hobby Lobby Stores, Inc., 573 U.S. 682, 701-02 (2014).

13. See Masterpiece Cakeshop, Ltd. v. Colo. Civil Rights Comm'n, 138 S. Ct. 1719, 1724 (2018).

14. See Fulton v. City of Philadelphia, 922 F.3d 140, 148 (3d Cir. 2019), cert. granted, No. 19123, 2020 WL 871694 (U.S. Feb. 24, 2020) (mem.). 
confirmation surgery ${ }^{15}$ and physician-assisted suicide. ${ }^{16}$ These types of refusals to accept the moral standards of contemporary secularism have dominated the free exercise exemption space for years. And it has generated backlash. After a series of Supreme Court decisions highly protective of free exercise, as well as controversial state measures intended to broaden exemptions for conservative causes, secular liberals began to argue for far narrower religious exemptions in light of thirdparty harms and discriminatory impacts on women and the LGBTQ community. ${ }^{17}$ Some began to question even the value of religious freedom. ${ }^{18}$ Indeed, after decades of the culture wars, this identification of religious freedom with conservative causes has hardened along party lines. Democratic Senators have explicitly criticized the conservative faith of judicial nominees. ${ }^{19}$ And in May 2019, a Democratic-majority House of Representatives passed the Equality Act, which protects persons from discrimination on the basis of sexual orientation and gender

15. See Minton v. Dignity Health, 252 Cal. Rptr. 3d 616, 619 (Ct. App. 2019).

16. See Complaint for Declaratory Relief at 2, Mahoney v. Centura Health Corp., No. 2019CV031980 (Colo. Dist. Ct. Aug. 21, 2019), 2019 WL 6456775.

17. See generally Douglas Nejaime \& Reva Siegel, Conscience Wars: Complicity-Based Conscience Claims in Religion and Politics, 124 YALE L.J. 2516 (2015) (highlighting the ways in which accommodation affects third parties); Elizabeth Sepper, Zombie Religious Institutions, 112 NW. U. L. REV. 929 (2018) (identifying healthcare as an institution that expands to adopt religious identities through mergers and acquisitions, even though many of those institutions no longer have religious ties); Leslie C. Griffin, A Word of Warning from a Woman: Arbitrary, Categorical, and Hidden Religious Exemptions Threaten LGBT Rights, 7 ALA. C.R. \& C.L. L. REV. 97 (2015) (arguing that religious exemptions threaten to erode LGBTQ rights); Thomas C. Berg, Progressive Arguments for Religious Organizational Freedom: Reflections on the HHS Mandate, $21 \mathrm{~J}$. Contemp. Legal Issues 279, 284 (2013) [hereinafter Berg, Progressive Arguments] ("As the HHS mandate dramatizes, there is an increasingly strong impulse, especially on the left, to limit the free exercise of religious institutions to the narrow confines of the house of worship.").

18. See Douglas Laycock, Religious Liberty and the Culture Wars, 2014 U. ILL. L. REV. 839, 869-77 (2014) [hereinafter Laycock, Culture Wars] ("The academic arguments against religious liberty grow more elaborate in the law reviews, more hostile in the list serves.").

19. See, e.g., Patrick L. Gregory, Senators Spar on Religious Questions at Trump Judge Pick Hearing, BLOOMBERG L. (June 5, 2019, 11:58 AM), https://news.bloomberglaw.com/us-law-week /senators-spar-on-religion-questions-at-trump-judge-pick-hearing [https://perma.cc/93JD-FK8F] (discussing Senators Kamala Harris and Mazie Hirono's criticism of judicial nominee Brian Buescher and noting that Senator Hirono stated "[n]o Democratic senator has suggested that membership in an organization makes a nominee unfit for the bench, only those who can't be fair or impartial"); C.C. Pecknold, Democrats Find Another Religious Heretic, WAll StREet J. (Sept. 13, 2017, 1:27 PM), https://www.wsj.com/articles/democrats-find-another-religious-heretic-1505323653 [https://perma.cc/A9W4-M67S] (stating several Democratic senators implied "not that you couldn't be a Catholic and uphold the law, but that you couldn't be an orthodox Catholic and do so"); Emma Green, Bernie Sanders's Religious Test for Christians in Public Office, ATlanTIC (June 8, 2017), https://www.theatlantic.com/politics/archive/2017/06/bernie-sanders-chris-van-hollen-russell-vought /529614/ [https://perma.cc/6HXV-J7RP] (noting Senator Bernie Sanders "questioned the faith" of Russell Vought, the nominee for deputy director of the Office of Management and Budget). 
identity. ${ }^{20}$ The Act contains no religious exemptions and explicitly provides that no court can mandate one under federal law. ${ }^{21}$

The sheer existence of increasingly visible progressive religion disrupts the entrenched polarized narratives of "religious conservatives" and "secular liberals."22 "Religious liberals" or "religious progressives," as I will call them interchangeably, are living proof that religious freedom entails far more than refusing to bend to current sexual and reproductive norms. ${ }^{23}$ Throughout American history, religious progressives have been center stage in major moral, political, and legal movements: abolition, social gospel, unionization and workers' rights, civil rights, just war, and protections for religious and racial minorities. Religious liberals have used the power of protest and persuasion, education at the grass roots level, and advocacy in courts, legislatures, and agencies to effect change. They have also sought exemptions in courts, legislatures, and agencies for causes as varied as conscientious objection to war and sanctuary for the undocumented. Many religious groups and coalitions now work to address issues of environmental protection, nativism and racism, poverty, criminal justice, death penalty, immigration reform and sanctuary, trafficking, war, and torture. ${ }^{24}$ They continue to advocate for the protection of religious minorities. ${ }^{25}$ Indeed,

20. Equality Act, H.R. 5, 116th Cong. (2019).

21. Id. $\S 1106$. The bill states that the Religious Freedom Restoration Act (RFRA) is not applicable to it. Id. § 1107. Additionally, in 2018 (and again in 2019) Democrats in the House and Senate proposed the Do No Harm Act, which carves out sexual orientation, gender identity, and abortion from RFRA protection. H.R. 1450, 116th Cong. (2019); S. 593, 116th Cong. (2019). Currently under consideration in the House, the Do No Harm Act would amend the RFRA itself, making it not applicable when a third party is burdened. H.R. 1450, $§ 2$. For a discussion of RFRA, see Section II.A.

22. See Steven H. Shiffrin, The Religious Left and Church State Relations 97-109 (2009) (arguing that secular liberals should support religious freedom because religious liberals support many secular liberal causes and explaining that the secular-liberal suspicion of religious freedom only makes them look hostile toward religion and undermines liberal political causes).

23. See Lund, supra note 11, at 164-65.

24. See generally Melissa Rogers, Faith in American Public Life (2019) (addressing attacks, hostility, and threats directed at religious minorities). Also note the work of the Religious Liberty Committee, originally of the National Council of Churches and now sponsored by the Religious Freedom Center of the Newseum Institute, which for nearly sixty years has convened meetings of lawyers from numerous religious denominations across the political spectrum to discuss issues on multiple church-state topics and to create opportunities for collaboration in many areas of public policy. See The Committee on Religious Liberty, RELIGIOUS FrEEDOM CTR., https://www.religiousfreedomcenter.org/about/crl/ [https://perma.cc/3E5P-2T4F] (last visited Mar. 5, 2020).

25. See ROGERS, supra note 24, at 199; Lund, supra note 11, at 164 ("The majority of RFRA and state RFRA cases have little to do with discrimination or sexual morality or the culture wars."). 
in the Trump era:

Frustrated by Christian conservatives' focus on reversing liberal successes in legalizing abortion and same-sex marriage, those on the religious left want to turn instead to what they see as truly fundamental biblical imperatives - caring for the poor, welcoming strangers and protecting the earth - and maybe even change some minds about what it means to be a believer. ${ }^{26}$

But the story is not so simple as the dispute between pro-exemption religious conservatives and anti-exemption secular liberals, with religious liberals now seeking exemptions. A deep tradition exists among many religious progressives that shares the secular liberal concern over the disadvantages and inequities that can flow from an overzealous accommodation of religion. ${ }^{27}$ Although they have long supported free exercise, religious liberals view some of the conservative arguments as so extreme that they endanger religious liberty more broadly. ${ }^{28}$ In fact, they resist the particular type of "robust" free exercise advocacy of the conservative narrative out of concern that it "tarnish[es] their own faith, or religion in general, by association." 29 Yet the resurgence of progressive religious claims, together with a lack of coordination and uniform messaging, presents the exemption question in fresh ways. This litigation is sure to confound expectations on all sides. $^{30}$

26. Laurie Goodstein, Religious Liberals Sat Out of Politics for 40 Years. Now They Want in the Game., N.Y. TimES (June 10, 2017), https://www.nytimes.com/2017/06/10/us/politics/politicsreligion-liberal-william-barber.html [https://perma.cc/XV7B-NUUZ].

27. See, e.g., Frederick Mark Gedicks, Towards a Defensible Free Exercise Doctrine, 68 GEO. WASH. L. REV. 925, 927-28 (2000) ("[R]eligious practices should receive the same kind of constitutional protection afforded to expression and association under the Speech and Equal Protection Clauses."); Frederick Mark Gedicks \& Rebecca G. Van Tassell, RFRA Exemptions From the Contraception Mandate: An Unconstitutional Accommodation of Religion, 49 HARV. C.R.-C.L. L. REV. 343, 372-83 (2014) (arguing that the material cost shifting entailed by RFRA exemptions violates the Establishment Clause). But see Berg, Progressive Arguments, supra note 17, at 298 ("[I]t is ironic and mistaken for progressives to deny or minimize religious-freedom protection for faith-based service organizations .... Works of justice, mercy, and service lie at the core of many religious faiths, but especially those that describe themselves as "progressive."').

28. See, e.g., Laycock, Culture Wars, supra note 18, at 840.

29. Berg, Progressive Arguments, supra note 17, at 331; see also Nicholas Kristof, Opinion, We're Less and Less a Christian Nation, and I Blame Some Blowhards, N.Y. TIMES (Oct. 26, 2019), https://www.nytimes.com/2019/10/26/opinion/sunday/christianity-united-states.html [https://perma.c c/F4MS-U6WE] (stating that Gregory Smith of the Pew Research Center noted "the data seem[s] consistent" with scholarly claims "that young adults have turned away from organized religion because they are repulsed by its entanglements with conservative politics").

30. For a discussion of liberal religious liberty claims, broadly defined, see ELIZABETH REINER Platt et al., Columbia law School, Law, Rights, \& Religion Project, Whose Faith MATters? THE Fight FOR Religious Liberty Beyond the Christian Right (2019), 
In this Article, I use the labels "conservative" and "liberal," "traditional" and "progressive" to describe religious beliefs, practices, individuals, communities, and traditions. As a general matter, I denote as "liberal" religiously motivated service on behalf of the poor, the immigrant and refugee, and the environment. ${ }^{31}$ But I use this terminology with great reluctance, not only because it can be underinclusive, overinclusive, or otherwise inaccurate in a given case but especially because it further politicizes faith. Most religious traditions have moral and social teachings that long pre-date and span the polarized divide of current U.S. politics; they typically caution against partisan alignment. Catholic leaders have been staunchly conservative on culture war issues but are quite progressive on immigration matters. And, of course, shifting alliances often occur, as we see some conservative communities begin to rethink environmental stewardship. Moreover, love of neighbor can be manifested in endless and surprising ways, unbounded by political categories. Nevertheless, given the political realities of these last forty years, with both church and state reinforcing a nationwide polarization, ${ }^{32}$ the conservative-liberal chasm is now so deep that I use the terms descriptively, though not normatively.

This Article offers several significant observations. First, it describes the distinctive ways in which conservative and liberal claims "present" in litigation. Next, it uncovers some inequities in the way these claims are addressed, with liberal claims sometimes at a disadvantage. Finally, it notes that despite these vulnerabilities, liberal claims are more likely to be protected when their religious exercise occurs on private property.

\section{A. The Distinction Between Refusal and Affirmative Claims}

This Article divides free exercise claims into two categories: refusal and affirmative. Refusal claims arise when a law or government policy mandates a person to act in ways that are contrary to her faith, and she

https://lawrightsreligion.law.columbia.edu/sites/default/files/content/Images/Whose\%20Faith\%20M atters\%20Full\%20Report\%2012.12.19.pdf [https://perma.cc/9A6Q-3H8R] [hereinafter WHOSE FAITH MATTERS?].

31. I use the terms to describe acts and not necessarily entire religious communities, for many conservative churches serve the poor and many liberal churches that support a pro-choice legal system are ethically pro-life.

32. See, e.g., Marc O. DeGirolami, Constitutional Contraction: Religion and the Roberts Court, 26 STAN. L. \& POL'Y REV. 385, 396 (2015) (noting the Supreme Court has grown more polarized, as seen by "a reduction in the range of voting patterns in law and religion cases," with "[t]he votes of the Justices over the last decade in law and religion cases overwhelmingly reflecting only two distributional patterns: unanimity or a 5-4 split" along liberal-conservative lines). 
refuses to comply. Most conservative free exercise claims today are refusal claims: a health care law requires a religious employer to provide contraception insurance coverage, and he refuses to comply on religious grounds, ${ }^{33}$ or a public accommodations law requires a florist to provide floral arrangements for a gay couple's wedding, and she refuses to comply on religious grounds. ${ }^{34}$ But there is nothing inherently conservative about refusal claims. They dominate in culture war litigation only because the objectionable mandates were enacted by politically liberal legislatures and agencies. In fact, the oldest refusal claim - military conscientious objection - is widely identified as a liberal objection, particularly since the Vietnam era. ${ }^{35}$

Refusal claims originate with the law because they are provoked by a law. In contrast, affirmative claims involve religious exercise that originates with the claimant's faith. A religious person or entity engages in conduct in accordance with faith, but the conduct is met with legal restraint - a law prohibiting or curtailing that religious exercise. ${ }^{36}$ Most liberal free exercise claims are affirmative claims: a church desires to establish a program to shelter the homeless but zoning laws prevent it; ${ }^{37}$ an individual helps a refugee and is arrested for criminal harboring of an undocumented person. ${ }^{38}$ In such situations, the law does not mandate an act that conflicts with religion, but rather restrains a religious act.

There is nothing inherently liberal about affirmative claims. It just so happens that in our current day, efforts to help the poor, the

33. Burwell v. Hobby Lobby Stores, Inc., 573 U.S. 682, 703 (2014).

34. State v. Arlene's Flowers, Inc., 441 P.3d 1203, 1210 (Wash. 2019), petition for cert. filed, No. 19-333 (U.S. Sept. 11, 2019). Note that I separate refusal claims into two categories: participation and endorsement. Angela C. Carmella, When Businesses Refuse to Serve for Religious Reasons: Drawing Lines Between "Participation" and "Endorsement" in Claims of Moral Complicity, 69 RUTGERS U. L. REV. 1593, 1596 (2017).

35. See, e.g., David B. Kopel, Evolving Christian Attitudes Towards Personal and National Self-Defense, 45 CONN. L. REV. 1709, 1741-43 (2013).

36. For refusal claims, the law requires an action of the religious party. For affirmative claims, the religion propels the action that the law restrains. In the former, the government is the assertive party. In the latter, the religious party is assertive. Note that either type of claim can be brought against laws that are generally applicable and facially neutral. A religious party might refuse to follow a neutral general requirement or might challenge a neutral general restraint on its religious exercise. If the government mandates or restrains in a way that targets only religious actors or conduct, that is likely a Free Exercise violation under Employment Division v. Smith, 494 U.S. 872 (1990).

37. See, e.g., Pitts, supra note 7.

38. See Teo Armus, After Helping Migrants in the Arizona Desert, an Activist Was Charged with a Felony. Now, He's Been Acquitted, WASH. PosT (Nov. 21, 2019, 6:03 AM), https://www.washingtonpost.com/nation/2019/11/21/arizona-activist-scott-warren-acquitted-charges -helping-migrants-cross-border/ [https://perma.cc/A6DQ-ASDP]. For a discussion of Dr. Scott Warren's case, see infra notes $427-45$ and accompanying text. 
immigrant, and the environment all take place in a heavily regulated environment. Indeed, although religious freedom claims now often fall along partisan lines, there are plenty of examples of liberal refusal claims and conservative affirmative claims. For instance, in response to a Minnesota law that required churches to allow guns in their parking lots, a liberal church refused to comply and challenged the mandate. ${ }^{39}$ In contrast, a conservative church brought an affirmative claim in response to a Georgia law that made it a misdemeanor to carry a gun into a place of worship. ${ }^{40}$ The church sought an exemption so that its members could carry guns for security during services. ${ }^{41}$

To understand the scope of affirmative claims requires a deeper understanding of the relationship between religious traditions and the exercise of faith. We often think about religion as expressions of specific commands, perhaps with rules governing even the details of daily life. But other religious commands are general: love your neighbor, serve the poor, welcome the stranger, care for creation. In this context, it is up to specific religious individuals and communities, using the hermeneutics of their texts, the ceremonies of their ancestors, or examination of conscience, to decide the ways in which these commands will be manifested and expressed, that is, how their faith will be inculturated. $^{42}$ How one serves the poor or welcomes the stranger or cares for creation will be guided by theological principles and the particularities of time, place, history, and circumstances, which means that most religious acts are not fixed at all times and all places but are inherently fluid, indeterminate, contextualized, and discretionary. These types of indeterminate religious acts are "affirmative" acts. Any given act might be legally permissible in certain circumstances, but unlawful in others. ${ }^{43}$ For instance, Dr. Scott Warren's humanitarian outreach may

39. Edina Cmty. Lutheran Church v. State, 745 N.W.2d 194, 198-99 (Minn. Ct. App. 2008). The church's refusal claim prevailed when the state appellate court found that the law substantially burdened religion by forcing churches "to act in a manner that is inconsistent with their religious beliefs" in violation of the state's constitution. Id. at 204-05.

40. GeorgiaCarry.Org, Inc. v. Georgia, 687 F.3d 1244, 1248-49 (11th Cir. 2012).

41. Id. at 1249 . The Eleventh Circuit denied this affirmative claim, finding the desire to carry a gun to be a personal preference, and not to involve religion. Id. at 1258 .

42. While the term "inculturate" is often used in the context of missionary work, it is also used more generally to mean the way in which religious beliefs become incarnate in a given culture. That is how it is used in this Article. See, e.g., Stephen B. Bevans, Models of Contextual TheOlogy 26-27 (rev. \& expanded ed. 2002); InT'L THEOlOGICAL COMM'N, FAITH AND INCULTURATION (1988), http://www.vatican.va/roman_curia/congregations/cfaith/cti_documents/rc cti_1988_fede-inculturazione_en.html [https://perma.cc/F7LF-G5ST].

43. This Article focuses on individual acts because the law restrains specific religious conduct. Faith is obviously far more than a sum of these actions. 
have been allowed in many places and under many conditions, but when given to undocumented migrants under a harsh federal policy, prosecutors treated the humanitarian outreach as a felony. ${ }^{44}$

To say that religious exercise is indeterminate or discretionary is not to say that it is undertaken lightly, or by mere whim or preference. In many cases, the religious individual experiences her "choice" as deeply as those whose faith mandates highly particularized rules and requirements. Dr. Warren believed that he had no choice but to aid individuals who crossed the border. ${ }^{45}$ And even when alternatives exist, choosing the means by which to exercise faith remains a theological determination that rests with the religious actor. The Supreme Court has said as much when it defers to religious claimants' judgment on the exercise of their religious convictions. ${ }^{46}$

Refusal claims are narrower than affirmative claims because they directly respond to a particular legal mandate: Do this; no, I will not. The law requires a person to act in a way that violates some religious tenet. Religion appears in these situations to be unassailably rule-based: thou shall not be involved in abortion, same-sex marriage, war, and the like. While refusal claims are generated by what the law requires, affirmative claims are guided instead by what a religion teaches. Faith, not the state, says, "Do this." Thus, affirmative claims, as their name suggests, are immensely wide ranging.

\section{B. What the Distinction Uncovers: Affirmative Claims Face More Doctrinal Obstacles}

In contrast to refusal claims, affirmative claims face doctrinal obstacles wherever strict scrutiny regimes are applicable, such as under federal or state statutes. In particular, it may be harder to establish a

44. Federal prosecutors charged Dr. Warren with two felony harboring charges after authorities raided an Ajo migrant aid station in January 2018. Five months after a jury deadlocked on the charges against him, however, Dr. Warren received a not guilty verdict in his retrial on November 21, 2019. Bobby Allyn, Jury Acquits Aid Worker Accused of Helping Border-Crossing Migrants in Arizona, NPR (Nov. 21, 2019), https://www.npr.org/2019/11/21/781658800/jury-acquits-aidworker-accused-of-helping-border-crossing-migrants-in-arizona [https://perma.cc/K4HL-QH2K].

45. Paul Ingram, No More Deaths Volunteer Testifies Leaving Water for Migrants Is a 'Sacred Act,' TuCsON SENTINEL (May 7, 2019, 2:45 AM), http://www.tucsonsentinel.com /local/report/050719_warren_trial/no-more-deaths-volunteer-testifes-leaving-water-migrants-sacredact/ [https://perma.cc/2MDF-E3S3] [hereinafter Ingam, No More Deaths Volunteer Testifies].

46. See Thomas v. Review Bd., 450 U.S. 707, 715 (1981) ("Thomas drew a line, and it is not for us to say that the line he drew was an unreasonable one.”); see also Burwell v. Hobby Lobby Stores, Inc., 573 U.S. 682, 724 (2014) (framing the proper RFRA issue as "whether the HHS mandate imposes a substantial burden on the ability of the objecting parties to conduct business in accordance with their religious beliefs"). 
substantial burden on religious exercise for an affirmative claimperhaps because there is no government coercion or because there are alternative ways to exercise one's faith. For some courts, the existence of alternatives might be dispositive. Courts that ask whether the religious claimant could have chosen a different way to serve the poor or protect the undocumented may find no conflict between law and faith, and thus no burden. Moreover, affirmative claims are at the mercy of multiple tests for identifying a substantial burden, which vary from circuit to circuit and state to state. Refusal claims typically do not suffer from such vulnerabilities at the substantial burden stage, since coercion is clearly met, and the direct conflict between the mandate and religious refusal is clear. Thus, while success is never assured, affirmative claimants - now predominantly progressive causes - may face a more difficult road.

\section{Affirmative Claims on Private Property Fare Better Than on Public Property}

Even with these obstacles, affirmative claims may fare better when religious exercise is conducted on private property, as when liberal churches seek to serve the poor and care for the environment on their own property. Those actions are anchored by the protection of ownership, which is missing when ceremonies and ministries are conducted on publicly owned lands. The protections for religious conduct on public property depend upon a variety of constitutional doctrines that may or may not apply.

This Article is organized as follows: Part II describes the development of the conservative religious liberty narrative, with its predominance of refusal claims, as reinforced most recently by the Trump administration. Part III explores the role of religious liberals in promoting progressive causes over the last fifty years and leading up to the 2016 election. Part IV describes the current progressive religious freedom litigation and the interpretive obstacles.

This Article does not intend to suggest that religious liberals should organize and model their litigation strategies after religious conservatives or try to out-compete them to win broad exemptions. Such a strategy has dangers of its own. ${ }^{47}$ Nevertheless, the unmitigated presence of

47. I have written elsewhere of the dangers of "endless litigation," which tempts litigants to make extreme arguments, invites government aggression, and threatens collaborative efforts on shared social goals. See Angela C. Carmella, Catholic Institutions in Court: The Religion Clauses and Political-Legal Compromise, 120 W. VA. L. REV. 1, 7-8 (2017) [hereinafter Carmella, Catholic 
progressive litigants now in the free exercise space begins to challenge the entrenched conservative and liberal narratives regarding the meaning and scope of religious freedom. It raises a different set of moral concerns for public discourse and may offer different views of the purpose and value of religious freedom. It challenges the narrow conception of rule-based religion with claims that often involve religious indeterminacy and fluidity. Further, the rise in visibility of liberal religious claims serves as a reminder that progressives, like traditionalists, can find themselves out of step with majority norms and dependent upon the continued salience and endurance of private institutional and associational freedoms. It forces a reconsideration of the notion of complicity, which has been tied so closely to the conservative narrative. For all these reasons, the hodgepodge of progressive litigants can contribute significantly to an ever-evolving political and juridical compromise among multiple religious freedom narratives.

\section{THE DEVELOPMENT OF THE RELIGIOUS CONSERVATIVE NARRATIVE}

The modern constitutional understanding of religious freedom entails a double immunity, encompassing "immunity from both coercion and restraint." "48 These two immunities present differently, as refusal claims and affirmative claims, respectively. The first immunity provides that government cannot force one to act in a manner contrary to faith. Here, a religious actor will bring a refusal claim, objecting to the law that requires conduct in conflict with her faith. The second immunity provides that government cannot restrain one from acting in accordance with faith. In such a case, a religious actor will bring an affirmative claim, seeking freedom to do what the law forbids. ${ }^{49}$ In either case, the typical remedy sought is an exemption.

The modern free exercise jurisprudence, fully embracing this double immunity, was squarely set to protect religious minorities. But by the

Institutions]. Additionally, "the rush to litigate takes a toll on [a church's] identity as a religiousmoral community, as its public presence begins to mirror that of any political actor. The loss of distinctive public characteristics of a moral community risks narrowing some of the very constitutional and statutory protections it seeks." Id. at 8.

48. Angela C. Carmella, John Courtney Murray, S.J. (1904-1967), in 1 The TeaChings of MODERn Christianity ON LAW, POLITICS, AND Human NATURE 115, 128 (John Witte Jr. \& Frank Alexander eds., 2006).

49. Of course, legal restraints also involve coercion. Both coercion and restraint involve legal penalties for failing to comply with the law, and so fulfill the threshold requirement of coercion for a free exercise claim as set out in Lyng v. Northwest Indian Cemetery Protective Ass'n, 485 U.S. 439, 448 (1988). 
1970s and 1980s, as the culture wars began to politicize and polarize religious communities into traditionalist and progressive camps, conservative churches tried to stem the tide of changing sexual mores and, when that failed, to seek exemptions. The exemptions - judicial, legislative, and regulatory-have been based on refusal claims. The Trump administration has explicitly reinforced the notion that religious freedom is primarily about protecting traditionalists from the encroachment of liberal mores on sexuality and family matters. ${ }^{50}$

\section{A. The Beginnings of Modern Free Exercise: The Protection of Religious Minorities}

Today's polarized narratives between religious conservatives and secular liberals differ from earlier narratives about religious freedom. From 1963 until the early 2000s, the predominant narrative was a liberal one: that broad free exercise protections were necessary to protect minority faiths. ${ }^{51}$ In the first Warren Court interpretation of the Free Exercise Clause, liberal Justice Brennan announced that religious claims would enjoy a strict scrutiny standard of review. ${ }^{52}$

In Sherbert $v$. Verner, South Carolina denied unemployment compensation to Adele Sherbert, a Seventh-day Adventist, who was fired for refusing to work on Saturdays, her sabbath. ${ }^{53}$ Because there were jobs in her field available on Saturdays, the state deemed her religious reason for refusing them inappropriate. ${ }^{54}$ The Supreme Court held that the state could not condition a government benefit on giving up one's religious practice without a compelling justification, and that no such

50. See William P. Barr, Att'y Gen., U.S. Dep't of Justice, Attorney General William P. Barr Delivers Remarks to the Law School and the de Nicola Center for Ethics and Culture at the University of Notre Dame (Oct. 11, 2019), https://www.justice.gov/opa/speech/attorney-generalwilliam-p-barr-delivers-remarks-law-school-and-de-nicola-center-ethics [https://perma.cc/6SV78ZVX]; see also Jeff Sessions, Att'y Gen., U.S. Dep't of Justice, Attorney General Sessions Delivers Remarks at the Department of Justice's Religious Liberty Summit (July 30, 2018), https://www.justice.gov/opa/speech/attorney-general-sessions-delivers-remarks-department-justice-s -religious-liberty-summit [https://perma.cc/B4HD-84DD].

51. At the same time, the Supreme Court also protected religious minorities through its interpretation of the Establishment Clause. For instance, the Court struck school prayer in Engel $v$. Vitale, 370 U.S. 421 (1962), and Bible reading in Abington v. Schempp, 374 U.S. 203 (1963), as well as in-school religious instruction in Illinois ex rel. McCollum v. Board of Education, 333 U.S. 203 (1948). This gave considerable freedom to religious minorities and those of no faith, who had been in school environments where these "voluntary" practices were psychologically coercive and intimidating.

52. See Sherbert v. Verner, 374 U.S. 398 (1963).

53. Id. at 399.

54. Id. at 399-401. 
justification existed here. ${ }^{55}$ The Court noted that while majoritarian faiths (i.e., most Christians) could be easily accommodated by legislatures, minority faiths were less likely to get the attention of the political branches. ${ }^{56}$ Indeed, South Carolina had already accommodated Sunday worshippers by statute, ensuring they would never be put in the situation faced by a Sabbatarian like Adele Sherbert. ${ }^{57}$ The minority protection narrative was further enshrined in Wisconsin v. Yoder, a unanimous decision of the Burger Court that exempted Amish teenagers from compulsory high school attendance lest the worldly values learned in school threaten the survival of their community and faith. ${ }^{58}$

Sherbert and Yoder presented the issues as refusal claims. The Amish parents in Yoder refused to send their children to high school as was required by a compulsory education law. ${ }^{59}$ Sherbert involved an indirect refusal. Obviously, no law mandated Adele Sherbert to work on Saturdays. ${ }^{60}$ But it was clear that if she practiced her religion and refused to work on Saturdays, she would not qualify for government benefits because her unemployment would not be legitimate. ${ }^{61}$ Given this penalty, the state action was tantamount to a law mandating Saturday work. ${ }^{62}$ The refusal paradigm thus involves claims not only against laws that order a particular act but also against laws that indirectly order a particular act by withholding government benefits. ${ }^{63}$

The upshot of Sherbert-Yoder strict scrutiny was that religious claimants sought court-mandated exemptions from otherwise generally applicable laws. The claimant was required to demonstrate that a law imposed a burden on her religious exercise; the government was required to show that the law was the least restrictive way of advancing a compelling interest. Few claimants prevailed throughout the 1970s and 1980 s, as the Supreme Court routinely found government interests sufficiently compelling ${ }^{64}$ or deemed strict scrutiny inapplicable. ${ }^{65}$

\footnotetext{
55. Id. at $406-07$.

56. See id. at 406 .

57. Id.

58. 406 U.S. 205, 235-36 (1972).

59. Id. at 207.

60. See Sherbert, 374 U.S. at 403 (" $[\mathrm{I}] \mathrm{t}$ is true that no criminal sanctions directly compel appellant to work a six-day week.").

61. See id. at 404 (" $[\mathrm{I}] \mathrm{t}[\mathrm{is}]$ apparent that appellant's declared ineligibility for benefits derives solely from the practice of her religion....").

62. See id.

63. See discussion infra notes 191-97 and accompanying text.

64. See, e.g., United States v. Lee, 455 U.S. 252, 260 (1982) (finding a compelling interest in enforcing social security tax obligations).

65. See, e.g., O’Lone v. Estate of Shabazz, 482 U.S. 342, 349 (1987) (prison policy preventing
} 
In 1990, a conservative Supreme Court majority rejected strict scrutiny as unsustainable, and with it the minority protection narrative. ${ }^{66}$ In Employment Division v. Smith, Justice Scalia wrote that an authentic application of strict scrutiny would yield religious exemptions for all manner of minority practices, which would dangerously threaten the stability of society and lead to anarchy. ${ }^{67}$ The Court therefore abandoned the strict scrutiny standard and narrowed the reading of the Free Exercise Clause to prohibit only government suppression and discrimination targeted at religion. ${ }^{68}$ This ended the practice of court-mandated protection from neutral, generally applicable laws that inadvertently burden a particular group. ${ }^{69}$ Aggrieved parties, said the Court, should seek protection from legislatures, not courts:

[L] eaving accommodation to the political process will place at a relative disadvantage those religious practices that are not widely engaged in; but that unavoidable consequence of democratic government must be preferred to a system in which each conscience is a law unto itself or in which judges weigh the social importance of all laws against the centrality of all religious beliefs. ${ }^{70}$

In reaction to Smith, a broad coalition of religious and civil liberties groups and a massive bipartisan effort in Congress saved the strict scrutiny standard of review with two federal statutes. The 1993 Religious Freedom Restoration Act (RFRA) reinstated strict scrutiny as a statutory cause of action. ${ }^{71}$ Testimony at the congressional hearings overwhelmingly noted the need to address the suffering of religious

attendance at a weekly religious service); Goldman v. Weinberger, 475 U.S. 503, 506-07 (1986) (military regulation preventing wearing a yarmulke while in uniform); Bowen v. Roy, 476 U.S. 693, 707 (1986) (statute requiring welfare applicants to provide social security numbers); Lyng v. Nw. Indian Cemetery Protective Ass'n, 485 U.S. 439, 450-51 (1988) (claims involving government administration of property).

66. See Emp't Div. v. Smith, 494 U.S. 872, 885-86 (1990). At the same time, the Court continued to splinter on Establishment Clause interpretation, with conservatives more willing to accommodate church-state cooperation. See, e.g., Zelman v. Simmons-Harris, 536 U.S. 639, 653 (2002) (vouchers for religious schools); Hein v. Freedom From Religion Found., Inc., 551 U.S. 587, 592-93 (2007) (funds for faith-based services); Town of Greece v. Galloway, 572 U.S. 565, 569-70 (2014) (legislative prayer).

67. Smith, 494 U.S. at 888.

68. See id. at 890 .

69. Id. at 885. Note, however, that Smith did not overrule Sherbert or Yoder. Smith carved out areas in which strict scrutiny review still functions, such as individualized governmental assessments and hybrid constitutional claims. Id. at 881-82.

70. Id. at 890 .

71. 42 U.S.C. $§ 2000 \mathrm{bb}-1$ (2018). The Act's stated purpose was "to restore the compelling interest test as set forth in Sherbert v. Verner and Wisconsin v. Yoder." Id. § 2000bb(b) (citations omitted). 
minorities. $^{72}$ The language of the statute itself notes that even losses under the test mean only that courts are striking "sensible balances." 73 After the Court held that RFRA was unconstitutional as applied to the states in $1997,{ }^{74}$ Congress enacted the Religious Land Use and Institutionalized Persons Act (RLUIPA) ${ }^{75}$ with unanimous support in both the House and the Senate in 2000. ${ }^{76}$ The RLUIPA hearings again involved stories of restrictive land use laws and prison policies, and frequent discriminatory actions in both realms, leading to particularly severe burdens on minority faiths. ${ }^{77}$ RFRA currently applies to all federal law, and RLUIPA applies to state laws involving land use and prison administration. The strict scrutiny tests are identical in these sister statutes. $^{78}$ In addition to these federal efforts to turn back Smith, some states began to interpret their constitutions to require a strict scrutiny

72. See The Religious Freedom Restoration Act: Hearing on S. 2969 Before the S. Comm. on the Judiciary, 102d Cong. 32 (1992) [hereinafter Senate Hearing] (statement of Dallin H. Oaks, Quorum of the Twelve Apostles, Church of Jesus Christ of Latter-Day Saints) ("The worshippers who need protections are the oppressed minorities, not the influential constituent elements of the majority."); id. at 144-45 (statement of Forest D. Montgomery, Counsel, National Association of Evangelicals) ("[G]overnment officials who were formerly under obligation to be reasonable and attempt, if possible, to accommodate religious practice, are now free to impose laws without any regard for the religious sensibilities of minorities."); id. at 171-72 (statement of Nadine Strossen, President, ACLU) ("[I]t is particularly troubling that the Supreme Court showed such a callous view toward the religious rights, and, by analogy, other constitutional rights of the disempowered, the unpopular, the minority religious and racial groups, turning on its head our understanding that the primary purpose of the free exercise clause and other provisions of the Bill of Rights was precisely to protect those disempowered minorities."); see also Religious Freedom Restoration Act of 1991: Hearings on H.R. 2797 Before the Subcomm. on Civil \& Constitutional Rights of the H. Comm. on the Judiciary, 102d Cong. 118 (1992) [hereinafter House Hearings] (statement of Rep. Stephen Solarz, chief sponsor and author of RFRA) ("Justice Scalia... took the position that... accommodating the religious preferences of minority religions is a luxury which we cannot afford. It seems to me that religious liberty is, in fact, a fundamental American value, and that it is a necessity we cannot do without ....").

73. 42 U.S.C. $§ 2000 b b(a)(5)$ (2018).

74. City of Boerne v. Flores, 521 U.S. 507, 536 (1997) (declaring RFRA an invalid exercise of Congress's Fourteenth Amendment enforcement power).

75. $\S \S 2000 \mathrm{cc}-2000 \mathrm{cc}-5$.

76. 146 CONG. REC. H7191 (daily ed. July 27, 2000) (statement of the Speaker pro tempore) (noting no objections in the House of Representatives); 146 CONG. REC. S7779 (daily ed. July 27, 2000) (statement of the Presiding Officer) (noting no objections in the Senate).

77. See Cutter v. Wilkinson, 544 U.S. 709, 716 (2005) ("Before enacting [RLUIPA], Congress documented, in hearings spanning three years, that 'frivolous or arbitrary' barriers impeded institutionalized persons' religious exercise.”). See, e.g., 146 CONG. REC. S7774-76 (daily ed. July 27, 2000) (joint statement of Sens. Hatch and Kennedy); Protecting Religious Freedom After Boerne v. Flores (Part III): Hearing Before the Subcomm. on the Constitution of the H. Comm. on the Judiciary, 105th Cong. 37-45 (1999) (statement of Isaac M. Jaroslawicz, Director of Legal Affairs, Aleph Institute); Protecting Religious Freedom After Boerne v. Flores (Part II): Hearing Before the Subcomm. on the Constitution of the H. Comm. on the Judiciary, 105th Cong. 54-60 (1999) (statement of Donald W. Brooks, Reverend, Diocese of Tulsa, Oklahoma).

78. Compare 42 U.S.C. $\S 2000 \mathrm{bb}-1(\mathrm{~b})(1)-(2)(2018)$, with id. $\S 2000 \mathrm{cc}(\mathrm{a})(1)(\mathrm{A})-(\mathrm{B})$. 
standard of review for government burdens on religion, and others passed state-level RFRA-like laws to provide comparable protection. ${ }^{79}$

Both RFRA and RLUIPA were broadly bipartisan and passed with virtually unanimous support. ${ }^{80}$ They were not viewed as favoring a particular political view but rather as ensuring the most robust religious freedom possible in a pluralistic and complex society. ${ }^{81}$ Further, in the early 2000s both political parties recognized and supported the significant work of religious groups at the local level — in their charitable services, stabilizing impacts, and community building. A White House office that coordinates such efforts has been maintained by Republican and Democratic Presidents for over fifteen years. ${ }^{82}$

In the last few decades, however, the cultural and legal narrative has become politicized along new lines. The broadly bipartisan support for religious freedom generally and minority faiths in particular, which characterized Congress and many state courts and legislatures, has evaporated. ${ }^{83}$ Since conservatives can no longer count on traditionalist ethics on sex and the family being legislatively enshrined, they have actively sought judicial religious exemptions and have lobbied for state RFRA-like laws that would explicitly protect them from progressive laws regarding sexual orientation and reproductive rights. ${ }^{84}$ In turn, secular liberals and many religious liberals have grown distrustful of the very notion of free exercise exemptions. Indeed, in 2016, the Chairman of the U.S. Commission on Civil Rights, which Congress created to inform the development of civil rights policy, said that "[t]he phrases

79. See generally Lund, supra note 11.

80. Eugene Volokh, A Brief Political History of Religious Exemptions, WASH. Post (Jan. 21, 2015), https://www.washingtonpost.com/news/volokh-conspiracy/wp/2015/01/21/a-brief-politicalhistory-of-religious-exemptions [https://perma.cc/3J8P-PQET].

81. See id.

82. For a description of the programs established in the Bush and Obama White Houses, see White House Faith-Based \& Community Initiative, GEORGE W. BuSH WHITE HOUSE, https://george wbush-whitehouse.archives.gov/government/fbci/president-initiative.html [https://perma.cc/CS6ETDCU] (last visited Feb. 16, 2020); About the Office of Faith-Based and Neighborhood Partnerships, OBAMA WHITE HOUSE, https://obamawhitehouse.archives.gov/administration/eop/ ofbnp/about [https://perma.cc/3QSQ-PJVU] (last visited Feb. 16, 2020).

83. Adam Sonfield, Learning from Experience: Where Religious Liberty Meets Reproductive Rights, GUTTMACHER INST. (Jan. 5, 2016), https://www.guttmacher.org/gpr/2016/learningexperience-where-religious-liberty-meets-reproductive-rights [https://perma.cc/NH2C-PLQR].

84. See id. ("[Conservatives] have argued... that laws meant to promote access to contraception or equal treatment of same-sex marriage ... are unlawfully restricting the rights of certain Americans to live according to their religious beliefs."); see also Dan Nowicki, Ind. Faces Uproar That Veto of Ariz. Bill Avoided, USA TODAY (Mar. 31, 2015, 6:06 PM), https ://www.usatoday.com/story/news/politics/2015/03/31/indiana-religious-freedom-law-uproar-avoided -arizona/70738948/ [https://perma.cc/CFX8-LN2N] (discussing Indiana's "religious freedom" law, which was then the 20th state version of RFRA). 
'religious liberty' and 'religious freedom' will stand for nothing except hypocrisy so long as they remain code words for discrimination, intolerance, racism, sexism, homophobia, and Islamophobia, Christian supremacy or any form of intolerance." ${ }^{.5}$

\section{B. The Culture Wars: Forging a Linkage Between Religion and Conservative Causes and the Emergence of the "Refusal" Paradigm for Free Exercise}

Abortion, contraception, and LGBTQ rights have been the biggest issues of the culture wars. Abortion, an immensely controversial political and legal topic since its legalization in 1973, has not been a major religious freedom issue since then because of extensive legislative conscience protections. Federal and state laws enacted in the 1970s provide that no medical personnel or hospital refusing to provide or participate in an abortion on religious or moral grounds can be required to do so or be punished for refusing. ${ }^{86}$ These "conscience" or "refusal" clauses obviate the need for judicially mandated protections. ${ }^{87}$

In the 1990s, contraception emerged as a culture war issue when states began to pass women's equity laws, which required employers to provide insurance coverage for contraception. ${ }^{88}$ Although churches were exempt, nonexempt Catholic charitable agencies refused to provide the coverage and demanded exemptions in New York and Californiawithout success. ${ }^{89}$ Federal regulations promulgated in 2012 under the Affordable Care $\mathrm{Act}^{90}$ required most employers to provide insurance that guaranteed contraceptives to employees at no cost. ${ }^{91}$ The U.S.

85. U.S. COMM'N ON CIVIL Rights, PEACEFUl COEXISTENCE: RECONCILING NONDISCRIMINATION PRINCIPLES WITH CIVIL LIBERTIES 29 (2016), https://www.usccr.gov/pubs/ docs/Peaceful-Coexistence-09-07-16.pdf [https://perma.cc/7BSX-GG9G].

86. See Lucas Mlsna, Stem Cell Based Treatments and Novel Considerations for Conscience Clause Legislation, 8 IND. HEALTH L. REV. 471, 476-81 (2011) (describing federal and state health care conscience laws).

87. But see discussion of new regulatory protections for conscience infra notes $176-81$ and accompanying text.

88. Insurance Coverage of Contraceptives, GUTTMACHER INST. (Dec. 1, 2019), https:// www.guttmacher.org/state-policy/explore/insurance-coverage-contraceptives [https://perma.cc/C2U A-YLED].

89. See Catholic Charities of Sacramento, Inc. v. Superior Court, 85 P.3d 67, 108 (Cal. 2004); Catholic Charities of the Diocese of Albany v. Serio, 859 N.E.2d 459, 469 (N.Y. 2006).

90. Patient Protection and Affordable Care Act, Pub. L. No. 111-148, 124 Stat. 119 (2010) (codified as amended in scattered sections of 15, 26, 29, 30, and 42 U.S.C.).

91. Group Health Plans and Health Insurance Issuers Relating to Coverage of Preventive Services Under the Patient Protection and Affordable Care Act, 77 Fed. Reg. 8725, 8728 (Feb. 15, 2012) (codified at 26 C.F.R. pt. 54; 29 C.F.R. 2590; 45 C.F.R. 147). 
Department of Health and Human Services (HHS) crafted a workaround for religious nonprofits, under which they could opt out of the mandate and shift the coverage obligations to their insurers. ${ }^{92}$ In response, as outraged Catholic bishops and Evangelical Christian leaders decried what they saw as the Obama administration's assault on religious liberty, over one hundred lawsuits were filed-about half by family-owned businesses refusing to provide the coverage and the remainder by religious nonprofits refusing to sign the workaround form. ${ }^{93}$ In Burwell v. Hobby Lobby Stores, Inc., the Court, on a 5-4 split, held that a closely held for-profit corporation could make a RFRA claim and granted an exemption to the owners of objecting businesses, the Hahn family, and the Green family. ${ }^{94}$ Applying RFRA's strict scrutiny standard of review, the Court found that the rule substantially burdened the plaintiffs' religious beliefs because "it would violate their religion to facilitate access to contraceptive drugs or devices that operate after [conception]." 95 While the Court assumed the rule advanced a compelling interest, it considered the workaround developed for nonprofits a less restrictive alternative. ${ }^{96}$ The Court also heard the nonprofits' argument in Zubik v. Burwell, but did not reach the merits of their refusal claim. ${ }^{97}$

Throughout this same period, traditionalists also challenged laws permitting same-sex marriage. Beginning in 2000, liberal states began to recognize same-sex civil unions, ${ }^{98}$ and some then recognized same-sex marriage. $^{99}$ By 2015, the Supreme Court in Obergefell v. Hodges held

92. Burwell v. Hobby Lobby Stores, Inc., 573 U.S. 682, 698 (2014) (citing 45 C.F.R. § 147.131(b) (2018); 78 Fed. Reg. 39,870, 39,874 (July 2, 2013)).

93. See Birth Control Mandate Lawsuits, NAT'L ORG. FOR WOMEN, https://now.org/resource/ birth-control-mandate-lawsuits/ [https://perma.cc/97J7-WS2N] (last visited Mar. 5, 2020) (listing 100 plaintiffs that have filed lawsuits in opposition to the contraception mandate).

94. 573 U.S. at 772.

95. Id. at 703, 719-20. For those who believe that life begins at conception, contraceptive drugs and devices that operate post-conception are considered abortifacients. $I d$. at 701.

96. Id. at 728 .

97. 136 S. Ct. 1557,1560 (2016).

98. On July 1, 2000, Vermont became the first state to recognize civil unions between same-sex couples. VT. STAT. ANN. tit. 15, § 1204 (2012). The Vermont legislature recognized same-sex civil unions in response to the Vermont Supreme Court ruling in Baker v. State, which held that same-sex couples are entitled, under the Vermont Constitution, to the same "common benefits and protections" extended to married couples. 744 A.2d 864, 875 (Vt. 1999).

99. On November 18, 2003, Massachusetts became the first state to allow same-sex marriage after its highest court ruled that the state "may [not] deny the protections, benefits and obligations conferred by civil marriage to two individuals of the same sex who wish to marry." Goodridge v. Dep't of Pub. Health, 798 N.E.2d 941, 948 (Mass. 2003). 
that the entire nation must recognize same-sex marriage. ${ }^{100}$ During this period, Evangelical Christians, Catholics, and Latter-day Saints were actively involved in political efforts to stem this tide. ${ }^{101}$ After Obergefell, they actively sought legislative and judicial exemptions to protect traditionalist refusals: Catholic adoption agencies refused to place children with same-sex couples, ${ }^{102}$ Evangelical wedding vendors refused to provide goods and services to same-sex couples, ${ }^{103}$ and some state clerks and judges refused to issue marriage licenses and solemnize marriages. ${ }^{104}$ Some conservative states began to propose or enact their own RFRAs to protect such rights to refuse, some with explosive political and economic consequences. ${ }^{105}$

The conservative dissenters in Obergefell raised concerns that religious objectors were not sufficiently protected, and that nothing would stop the government from penalizing and excluding churches with beliefs in traditional marriage for being bigoted, discriminatory institutions. ${ }^{106}$ The dissent's concerns were taken up in Masterpiece Cakeshop v. Colorado Civil Rights Commission, where the Court admonished a state for showing disrespect and disparagement toward those who make refusal claims. ${ }^{107}$ In Masterpiece, a Christian baker refused to provide a wedding cake for a same-sex couple, claiming, inter alia, a religious exemption from public accommodations law. ${ }^{108}$ The Court did not reach the merits, but did find that the state civil rights commission treated him with "a clear and impermissible hostility toward the sincere religious beliefs that motivated his objection." "109 Two other cases involving wedding vendor refusal claims were remanded from the Supreme Court, and a new petition for certiorari has been filed by the wedding vendor in one of those cases. ${ }^{110}$

\footnotetext{
100. 135 S. Ct. 2584, 2591 (2015).

101. See Carmella, Catholic Institutions, supra note 47, at 61-62.

102. See Fulton v. City of Philadelphia, 922 F.3d 140, 147 (3d Cir. 2019), cert. granted, No. 19123, 2020 WL 871694 (U.S. Feb. 24, 2020) (mem.).

103. See Masterpiece Cakeshop v. Colo. Civil Rights Comm'n, 138 S. Ct. 1719, 1729 (2018).

104. See, e.g., Alan Blinder \& Tamar Lewin, Clerk in Kentucky Chooses Jail Over Deal on Same-Sex Marriage, N.Y TIMES (Sept. 3, 2015), https:/www.nytimes.com/2015/09/04/us/kimdavis-same-sex-marriage.html [https://perma.cc/94EX-URVB].

105. See Ira C. Lupu, Moving Targets: Obergefell, Hobby Lobby, and the Future of LGBT Rights, 7 ALA. C.R. \& C.L. L. REV. 1, 46-50 (2015).

106. Obergefell v. Hodges, 135 S. Ct. 2584, 2638 (2015) (Roberts, C.J., dissenting).

107. $138 \mathrm{~S}$. Ct. at 1729 .

108. Id. at 1723 .

109. Id. at 1729 .

110. See State v. Arlene's Flowers, 441 P.3d 1203, 1209 (Wash. 2019), petition for cert. filed,
} No. 19-333 (U.S. Sept. 11, 2019); Klein v. Or. Bureau of Labor \& Indus., 410 P.3d 1051, 1056 (Or. 
The liberal dissents in both Hobby Lobby and Masterpiece thought the protections had gone too far. Justice Ginsburg's Hobby Lobby dissent argued that RFRA should not apply to businesses but rather only to churches carrying out their religious purposes. ${ }^{111}$ The dissenters in Hobby Lobby were concerned that the impact of the exemption-the unavailability of insurance coverage for contraceptives-would be staggering. ${ }^{112}$ Moreover, the dissenters in Masterpiece argued that the harms to same-sex couples resulting from the baker's refusal far outweighed the comments of a few state commissioners that had not demonstrably infected the proceedings. ${ }^{113}$ Such calls for a narrowed scope of religious freedom focus on the avoidance of third-party harms and skepticism toward the legitimacy of refusal claims against contraception and same-sex marriage.

Many religious liberals were dismayed by the loss of all sense of proportion in exemption claims. The ease with which the Hobby Lobby Court found a substantial burden was troubling. The statutory word "substantial" qualifies the term "burden" for a reason. ${ }^{114}$ Further, religious liberals balked when conservative religious nonprofits refused to sign a form that made it possible for them to obtain the workaround exemption in Zubik, warning that "religious liberty can be endangered by exaggerated claims and overreaching as well as by government intransigence and judicial under enforcement." 115 They cautioned that legislatures would react by repealing existing religious exemptions or rejecting exemptions altogether. ${ }^{116}$

The culture wars continue unabated. Some liberal states require employer insurance to provide abortion coverage. ${ }^{117}$ Other states protect

Ct. App. 2017), cert. granted, judgment vacated, 139 S. Ct. 2713 (2019) (mem.).

111. Burwell v. Hobby Lobby Stores, Inc., 573 U.S. 682, 772 (2014) (Ginsburg, J., dissenting).

112. Id.

113. 138 S. Ct. at $1748,1751-52$ (Ginsburg, J., dissenting).

114. Frederick Mark Gedicks, "Substantial" Burdens: How Courts May (and Why They Must) Judge Burdens on Religion Under RFRA, 85 GEO. WASH. L. REV. 94, 120 (2017) [hereinafter Gedicks, "Substantial" Burdens].

115. Brief of Baptist Joint Committee for Religious Liberty as Amicus Curiae in Support of Respondents at 6, Zubik v. Burwell, 136 S. Ct. 1557 (2016) (Nos. 14-1418, 14-1453, 14-1505, 1535, 15-105, 15-119, 15-191), 2016 WL 692850.

116. Id. at 4.

117. See Adam Sonfield \& Elizabeth Nash, States Lead the Way in Promoting Coverage of Abortion in Medicaid and Private Insurance, GUTTMACHER INST. (June 24, 2019), https://www.guttmacher.org/article/2019/06/states-lead-way-promoting-coverage-abortion-medicaid -and-private-insurance [https://perma.cc/B9RX-9SDD] (listing California, New York, Oregon, Washington, Illinois, and Maine as states that require private insurance plans to cover abortion). In Foothill Church v. Rouillard, a California court evaluated a challenge to the requirement that employee health insurance include abortion coverage. 371 F. Supp. 3d 742 (E.D. Cal. 2019), appeal 
assisted reproduction coverage for same-sex couples, ${ }^{118}$ or require hospitals to provide abortions ${ }^{119}$ and contraception ${ }^{120}$ in emergency situations, regardless of religious or moral objection. Further, state legislatures and courts are embroiled in controversies over whether states must pay for gender confirmation treatment and surgery, and whether to provide religious or moral exemptions. ${ }^{121}$ Some conservative states recently passed restrictive abortion laws, ${ }^{122}$ as well as conscience laws that broadly protect refusals based on a belief in traditional marriage and gender immutability from discrimination claims or penalty. ${ }^{123}$ And conservatives continue to press for a federal First Amendment Defense Act, which would ensure that no penalties could attach to refusals based on traditional beliefs regarding sexual and family matters. ${ }^{124}$

Despite politically charged cases like Hobby Lobby and Obergefell, the Court has continued to protect religious minorities under RFRA and RLUIPA. Liberals and conservatives may disagree over the application of strict scrutiny in any given case, but three unanimous decisions bear

filed, No. 19-15658 (9th Cir. Apr. 8, 2019). The court dismissed the case for failure to state a claim on the grounds that the law is generally applicable and facially neutral. Id. at 750-53. But in January 2020, HHS issued a Notice of Violation to the State of California to notify the State "that it cannot impose universal abortion coverage mandates on health insurance plans and issuers in violation of federal conscience laws." Press Release, U.S. Dep't of Health \& Human Servs., HHS Issues Notice of Violation to California for Its Abortion Coverage Mandate (Jan. 24, 2020), https ://www.hhs.gov/about/news/2020/01/24/hhs-issues-notice-of-violation-to-california-for-its-abortioncoverage-mandate.html [https://perma.cc/6ANY-T98C].

118. See, e.g., MD. CodE ANN. INS. § 15-810 (West, Westlaw through 2019 Reg. Sess.).

119. See, e.g., CAL. HeAlth \& SAFETy CODE $§ 123420$ (West, Westlaw through Ch. 1 of 2020 Reg. Sess.).

120. For a description of emergency contraception policies by state, see Emergency Contraception, GUTTMACHER INST. (Feb. 1, 2020), https://www.guttmacher.org/state-policy/ explore/emergency-contraception [https://perma.cc/FG75-AHJQ].

121. See Michael Ollove, States Diverge on Transgender Health Care, Pew Charitable TRUSTS: STATELINE (July 17, 2019), https://www.pewtrusts.org/research-and-analysis/blogs/ stateline/2019/07/17/states-diverge-on-transgender-health-care [https://perma.cc/LH3N-H9P3]. At the federal level, the Trump administration plans to undo antidiscrimination protections within the Affordable Care Act. Id.

122. K.K. Rebecca Lai, Abortion Bans: 9 States Have Passed Bills to Limit the Procedure This Year, N.Y. TIMES (May 29, 2019), https://www.nytimes.com/interactive/2019/us/abortion-lawsstates.html [https://perma.cc/9288-YVNK].

123. See, e.g., H.B. 1523, 2016 Leg., Reg. Sess. (Miss. 2016). In 2016, the Mississippi Legislature passed H.B. 1523, which broadly protects those who believe in traditional marriage and gender immutability from adverse consequences, discrimination, or penalty. See id. Liberal clergy, among other plaintiffs, challenged the constitutionality of the statute under the Establishment Clause and the Equal Protection Clause of the Fourteenth Amendment. Barber v. Bryant, 860 F.3d 345, 350 (5th Cir. 2017). But the Fifth Circuit determined they lacked standing to bring the challenge. Id. at 358 ("The failure of the Barber plaintiffs to assert anything more than a general stigmatic injury dooms their claim to standing ....").

124. S. 2525,115 th Cong. $\S 3$ (2018). 
mentioning. In Cutter v. Wilkinson, prisoners brought RLUIPA claims against prison administrators who defended the statutory claims with an Establishment Clause challenge to the statute. ${ }^{125}$ Plaintiffs were all from nonmainstream religions, ${ }^{126}$ which is typical in prison litigation. The Court, in a unanimous decision, upheld RLUIPA, finding that increasing protection of prisoners' religious rights did not violate the Establishment Clause. ${ }^{127}$ The Court expressed confidence that RLUIPA, which adopts a "compelling governmental interest" standard, would "be applied in an appropriately balanced way" to specific cases to grant or deny exemptions. ${ }^{128}$

A year later, in Gonzales v. O Centro Espirita Beneficente Uniao do Vegetal, the Court, interpreting RFRA, held that a small religious group's sacramental use of an illegal drug must be exempt from the Controlled Substances Act. ${ }^{129}$ The federal government argued for uniformity but failed to demonstrate any difficulties with granting an exemption, especially given the experience with a pre-existing peyote exemption, which produced no ill effects on the Act's enforceability. ${ }^{130}$ It was not sufficient for the government to argue that the law "serves a compelling purpose and simply admits of no exceptions .... RFRA requires the Government to demonstrate that the compelling interest test is satisfied through application of the challenged law 'to the person'- the particular claimant whose sincere exercise of religion is being substantially burdened." 131

In 2015, the Court in Holt v. Hobbs held that Gregory Holt (also known as Abdul Maalik Muhammad), a Muslim prisoner, was exempt from a prison's facial hair prohibition under RLUIPA. ${ }^{132}$ Muhammad refused to shave his beard, and the Court held RLUIPA allowed him to

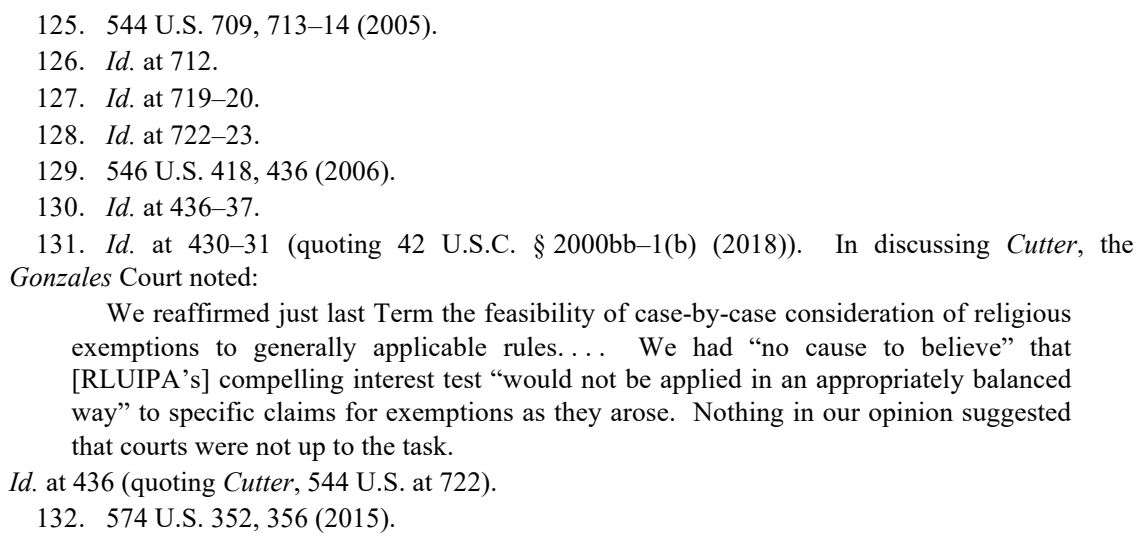


maintain a half-inch beard in accordance with his faith. ${ }^{133}$ The Court "doubt[ed] whether the prohibition against [Muhammad's] beard further[ed] its compelling interest about contraband," and "conclude[d] that the [prison] ha[d] failed to show that its policy [was] the least restrictive means of furthering its compelling interests." 134 With the Court's close look at government alternatives to burdening religious practices, Gonzales and Holt show that as courts "strik[e] sensible balances," they can indeed protect minority faiths. ${ }^{135}$

\section{The Trump Administration: Reinforcing Conservative Religious Freedom and the Dominance of Refusal Claims}

Donald Trump was elected President with the help of religious conservatives, especially the Evangelical community. ${ }^{136}$ Evangelicals, as well as the Catholic bishops, argued vehemently with the Obama administration over the contraceptive mandate ${ }^{137}$ and especially the separate workaround requirements for religious nonprofits. ${ }^{138}$ For many, the mandate represented a secular-liberal, big-government attack on religious freedom. ${ }^{139}$ The mandate galvanized religious conservatives, who painted a picture of Democrats as antireligious ideologues willing to

133. Id.

134. Id.

135. 42 U.S.C. $\S 2000 \mathrm{bb}(\mathrm{a})(5)$ (2018). In the same term as Holt, the Court, in an $8-1$ ruling, held that an employer that refused to hire a Muslim woman to avoid accommodating a religious practice because her headscarf "would conflict with the store's Look Policy" violated Title VII's requirement to accommodate religious practice. EEOC v. Abercrombie \& Fitch, 135 S. Ct. 2028, 2031 (2015). Justice Scalia, writing for the Court, explained that "the rule for disparate-treatment claims based on a failure to accommodate a religious practice is straightforward: An employer may not make an applicant's religious practice, confirmed or otherwise, a factor in employment decisions." Id. at 2033.

136. See, e.g., Sarah Pulliam Bailey, White Evangelicals Voted Overwhelmingly for Donald Trump, Exit Polls Show, WASH. POST (Nov. 9, 2016, 7:33 AM), https://www.washingtonpost.com /news/acts-of-faith/wp/2016/11/09/exit-polls-show-white-evangelicals-voted-overwhelmingly-for-do nald-trump/ [https://perma.cc/6DBM-7Y9Y].

137. See, e.g., U.S. Conference of Catholic Bishops, Office of Gen. Counsel, Comment Letter on Interim Final Rules on Preventive Services (Aug. 31, 2011), http://www.usccb.org/about/generalcounsel/rulemaking/upload/comments-to-hhs-on-preventive-services-2011-08.pdf [https://perma.cc/ 3P5G-X4U3] [hereinafter Comment Letter].

138. See Secretariat of Pro-Life ACtivities, U.S. Conference of Catholic Bishops, Twelve Things Everyone Should KnOw About the "Contraceptive Mandate” (2014), http://www.usccb.org/issues-and-action/religious-liberty/conscience-protection/upload/Twelve-Thin gs-Everyone-Should-Know-About-the-Contraceptive-Mandate.pdf [https://perma.cc/LT5D-YYRJ].

139. See Comment Letter, supra note 137, at 3 (arguing that the contraception mandate is a "nationwide government coercion of religious people and groups to sell, broker, or purchase 'services' to which they have a moral or religious objection," and "represents an unprecedented attack on religious liberty"). 
fine nonprofits and businesses out of existence when they refused to abandon their faith. ${ }^{140}$ The Trump agenda follows the conservative religious narrative; the administration holds itself out as a corrective to the previous liberal administration. ${ }^{141}$

\section{A Broad Religious Liberty Agenda}

In January 2017, within days of taking office, President Trump issued an executive order that introduced a travel ban, ${ }^{142}$ which implemented his campaign promise to order a "total and complete shutdown of Muslims entering the United States." "143 The Supreme Court later upheld the third version of that ban, which severely limited visas to citizens from five majority-Muslim nations. ${ }^{144}$

Liberals thought it hypocritical when, a few months later, Trump issued another executive order, this one on "Promoting Free Speech and Religious Liberty." 145 With conservative grievances toward the

140. See, e.g., Amanda Holpuch, Behind the Legal Challenge to Obamacare's Contraception Mandate, GUARDIAN (Mar. 24, 2014, 3:36 PM), https://www.theguardian.com/law/2014/mar/24/ hobby-lobby-sureme-court-obamacare-contraception [https://perma.cc/JAE3-PE2U] (noting that Mark Taylor, the president and CEO of the Christian publishing company Tyndale House, told a newspaper: "They [the government] are forcing us to do something that we feel is morally wrong, or they're going to charge us such huge fines that, over time, it would put us out of business." (alteration in original)).

141. See Emma Green, Trump: 'In America We Do Not Worship Government, We Worship God,' ATLANTIC (May 13, 2017), https:/www.theatlantic.com/politics/archive/2017/05/donald-trumpliberty-university/526650/ [https://perma.cc/9U46-49SL]. Official White House statements maintain that President Trump is a champion for religious freedom. See President Trump Has Been a Champion for Religious Freedom, WHITE HOUSE (Feb. 8, 2018), https://www.whitehouse.gov/ briefings-statements/president-trump-champion-religious-freedom/ [https://perma.cc/3W5L-RH9U]. For a contrasting view of Obama's religious freedom record, see Don Byrd, Highlights of Obama Administration's Church-State Record, BJC (Jan. 18, 2017), https://bjconline.org/highlights-of-oba ma-administrations-church-state-record-011820171/ [https://perma.cc/A3AY-69KV] (highlighting efforts to combat religious discrimination and provide support for faith-based neighborhood groups); Judd Birdsall, Commentary, Obama's Religious Freedom Record Is Strong, WASH. Post (Jan. 21, 2014), https://www.washingtonpost.com/national/religion/commentary-obamas-religious-freedomrecord-is-strong/2014/01/21/7dd57e08-82dc-11e3-a273-6ffd9cf9f4ba_story.html [https://perma.cc/ U4MJ-V396] (describing Obama's international religious freedom efforts).

142. Exec. Order No. 13,769, 82 Fed. Reg. 8977 (Jan. 27, 2017)

143. Abigail Hauslohner, During First Two Years of 'Muslim Ban,' Trump Administration Granted Few Waivers, WASH. POST (Sept. 24, 2019, 6:21 PM), https:/www.washingtonpost.com/ immigration/during-first-two-years-of-muslim-ban-trump-administration-granted-few-waivers/2019/ 09/24/44519d02-deec-11e9-8dc8-498eabc129a0_story.html [https://perma.cc/Y92W-SR5D].

144. Trump v. Hawaii, 138 S. Ct. 2392, 2423 (2018) (upholding Proclamation No. 9645, 82 Fed. Reg. 45,161 (Sept. 24, 2017)).

145. Exec. Order No. 13,798, 82 Fed. Reg. 21,675 (May 4, 2017); see also Exec. Order No. 13,831, 83 Fed. Reg. 20,715 (May 3, 2018) (establishing a White House Faith and Opportunity Initiative). The initiative, however, appears to be dormant. For criticism of the initiative, see Melissa Rogers, President Trump Just Unveiled a New White House 'Faith' Office. It Actually 
contraception mandate and the Obergefell decision still fresh, the order laid out a religious freedom agenda responsive to these concerns. ${ }^{146}$ First, it directed the Attorney General to issue "guidance interpreting religious liberty protections in Federal law." 147 Second, it directed the Secretaries of Labor, Treasury, and HHS to "consider issuing amended regulations, consistent with applicable law, to address conscience-based objections" to the contraceptive mandate. ${ }^{148}$ And third, it directed the Secretary of the Treasury to:

[E]nsure ... that the Department of the Treasury does not take any adverse action against any individual, house of worship, or other religious organization on the basis that such individual or organization speaks or has spoken about moral or political issues from a religious perspective, where speech of similar character has, consistent with law, not ordinarily been treated as participation or intervention in a political campaign on behalf of (or in opposition to) a candidate for public office by the Department of Treasury.

Each initiative is discussed below.

\section{a. The Attorney General's Guidance on Religious Liberty}

On October 6, 2017, then-Attorney General Jeff Sessions issued the Department of Justice (DOJ) Guidance Document on "Principles of Religious Liberty" in a memorandum for all executive departments and agencies entitled "Federal Law Protections for Religious Liberty." 150 The Guidance Document directs the DOJ to provide broad protection of religious freedom, echoing Hobby Lobby: "Except in the narrowest

Weakens Religious Freedom, WASH. POST (May 14, 2018), https://www.washingtonpost.com /news/acts-of-faith/wp/2018/05/14/president-trump-just-unveiled-a-new-white-house-faith-office-itactually-weakens-religious-freedom/ [https://perma.cc/2AG8-SMPS].

146. ROGERS, supra note 24 at 9-10 (noting that the Trump administration is responsive to conservative religious liberty claims, but not liberal ones).

147. Exec. Order No. 13,798, supra note $145, \S 4$.

148. Id. $\S 3$.

149. Id. § 2 .

150. Memorandum from Jeff Sessions, Att'y Gen., to All Exec. Dep'ts \& Agencies (Oct. 6, 2017), https://www.justice.gov/opa/press-release/file/1001891/download [https://perma.cc/459MUD2D] [hereinafter Religious Liberty Guidance Document]. Liberals immediately criticized the document. Matt Zapotosky \& Sarah Pulliam Bailey, Civil Liberties Groups Decry Sessions's Guidance on Religions Freedom, WASH. POST (Oct. 6, 2017), https://www.washingtonpost.com /world/national-security/civil-liberties-groups-decry-sessionss-guidance-on-religious-freedom/2017/ 10/06/cd5cfcde-aaa7-11e7-92d1-58c702d2d975_story.html [https://perma.cc/JU2F-WEJM]. For a discussion of the structures and processes for handling religion issues, see Melissa Rogers, Religious Freedom and the Federal Executive Branch: Suggestions for Future Administrations, 15 U. ST. THOMAS L.J. 703 (2019). 
circumstances, no one should be forced to choose between living out his or her faith and complying with the law."151 The Guidance Document sets forth twenty "principles of religious liberty," which include the right to act or abstain from acting; the extension of these rights to organizations, even some for-profit corporations; and the durability of these rights, which are not surrendered in order to participate in the marketplace, public square, or government programs. ${ }^{152}$

Two elements are worth noting in particular. The Guidance Document states that third party burdens, while relevant to RFRA analysis, do not automatically render an exemption unavailable. ${ }^{153}$ This position rejects the harsh liberal criticism of exemptions for conservative causes based on their negative effects on women, LGBTQ individuals, or others. Additionally, the Guidance Document broadens protections for religious employers receiving federal grants or contracts, because it forbids the government from conditioning the receipt of federal monies on requiring the grantee or contract party to give up its religious character or its hiring exemptions. ${ }^{154}$ The main impact is to protect religious entities that refuse to hire or retain LGBTQ individuals, an outcome that liberals vigorously oppose. ${ }^{155}$

Consistent with the Guidance Document, the DOJ sided with the baker in Masterpiece ${ }^{156}$ and supported the Archdiocese of Washington's

151. Religious Liberty Guidance Document, supra note 150 , at 1.

152. Id. at 1-7. The document further notes other important protections for religious freedom like Title VII and the Clinton-era Guidelines on Religious Exercise and Expression in the Federal Workplace. Id. at 5-6. Sessions also created a Religious Liberty Task Force to help implement the Guidance Document to ensure, in his words, that "all Justice Department components ... are holding that guidance in the cases they bring and defend, the arguments they make in court, the policies and regulations they adopt, and how we conduct our operations." Liz Boylan, Attorney General Sessions's "Religious Liberty Task Force": DOJ Evangelists for the Religious Right, MEDIUM (Aug. 1, 2018), https://medium.com/@PRPCP_Columbia/attorney-general-sessionsreligious-liberty-task-force-doj-evangelists-for-the-religious-right-26e8737451d6 [https://perma.cc/ 464D-CLUV] (alteration in original).

153. Religious Liberty Guidance Document, supra note 150, at $15 \mathrm{a}$.

154. Id. at 8 .

155. As Professor Tom Berg explained:

The new memo also defends applying statutory protections for "hiring persons of a particular religion" to include protection for religiously based standards of conduct for employees, including in the funding context-and potentially (although this is not said explicitly) when the category of prohibited discrimination that's asserted is sexual orientation, not just when it's religion.

Kate Shellnutt, 6 Things Trump's Religious Liberty Memo Does (and Doesn't) Do, CHRISTIANITY TODAY (Oct. 9, 2017, 11:08 AM), https://www.christianitytoday.com/news/2017/october/whattrump-religious-liberty-guidance-does-sessions-doj.html [https://perma.cc/X2M4-9MW9] (quoting Professor Tom Berg, University of St. Thomas law professor and religious liberty scholar).

156. See Brief for the United States as Amicus Curiae Supporting Petitioners, Masterpiece Cake Shop v. Colo. Civil Rights Comm'n, 138 S. Ct. 1719 (2017) (No. 16-111), 2017 WL 4004530. 
effort to buy Christmas advertisements on public transportation. ${ }^{157}$ The Supreme Court granted certiorari in EEOC v. R.G. \& G.R. Harris Funeral Homes, which frames the issue as whether Title VII protects transgender persons. ${ }^{158}$ In that case, a funeral owner refused to allow an employee on staff who intended to transition from male to female to wear the female uniform. ${ }^{159}$ The owner, seeking an exemption, argued unsuccessfully in the Sixth Circuit that authorizing or paying for a transgender female employee to wear the female uniform substantially burdened the owner's religious belief that one's sex is "an immutable God-given gift" in violation of RFRA, would hinder the grieving mourners' healing, and pressure the owner to leave the funeral ministry. ${ }^{160}$ Even though RFRA is not at issue in the Supreme Court, the DOJ supports the religious refusal claim, arguing that Title VII does not protect transgender persons. ${ }^{161}$

b. Reversal of the Contraceptive Mandate and Centralization of the Protection of Conscience

Although the Guidance Document defines religious freedom to include "the right to act or abstain from action," 162 the Trump administration is overwhelmingly concerned with protecting the latterrefusal claims. This goal comes into sharpest focus in efforts to reverse the contraception mandate and establish a centralized office for conscience-based refusal claims in the health care field.

On October 13, 2017, HHS, in collaboration with the U.S. Department of Treasury and the U.S. Department of Labor, issued two interim final rules to establish exemptions for employers and insurers

157. See Brief for the United States as Amicus Curiae Supporting Appellant, Archdiocese of Wash. v. Wash. Metro. Area Transit Auth., 897 F.3d 314 (2018) (No. 17-7171), 2018 WL 447339.

158. 884 F.3d 560, 566-67 (6th Cir. 2018), cert. granted, 139 S. Ct. 1599 (2019) (No. 17-1623) (mem.) (granting review only on the issue of "[w]hether Title VII prohibits discrimination against transgender people based on (1) their status as transgender (2) sex stereotyping").

159. Id. at 566 .

160. Id. at 569, 585-86. The Sixth Circuit held "as a matter of law that a religious claimant cannot rely on customers' presumed biases to establish a substantial burden under RFRA." Id. at 586. Further, "the fact that [the owner] sincerely believes that he is being compelled to make such an endorsement [of gender mutability] does not make it so." Id. at 589 (citing Eternal Word Television Network, Inc. v. Sec'y of U.S. Dep't of Health \& Human Servs., 818 F.3d 1122, 1145 (11th Cir. 2016)). The law does not force him to participate in gender transition. Id. Therefore, his claim that he feels pressure to either allow the employee to present as female or leave the business is pressure of his own creation. See id.

161. See Brief for the Federal Respondents in Opposition at 16-18, R.G. \& G.R. Harris Funeral Homes, No. 18-107 (U.S. Oct. 24, 2019), 2018 WL 5293597.

162. Religious Liberty Guidance Document, supra note 150 , at 2. 
with religious and moral objections from the contraceptive mandate. ${ }^{163}$ The 2017 Religious Interim Rule allowed any employer with objections based on religious beliefs to opt out of providing no-cost contraceptive coverage. ${ }^{164}$ This exemption included not only nonprofit entities but all for-profit entities, including publicly traded corporations, far beyond the closely held corporation exemption of Hobby Lobby. ${ }^{165}$ A federal district court in Pennsylvania, however, issued a nationwide preliminary injunction, enjoining the Trump administration from enforcing the interim final rules. ${ }^{166}$

While the appeal of the preliminary injunction was pending, HHS issued two final rules (2018 Final Rules) "virtually identical" to the 2017 interim final rules. ${ }^{167}$ On January 14, 2019, the day the 2018 Final Rules were scheduled to take effect, ${ }^{168}$ the federal district court in Pennsylvania issued another nationwide preliminary injunction. ${ }^{169}$ The Third Circuit affirmed, ${ }^{170}$ and the Supreme Court granted certiorari in January $2020 .{ }^{171}$

With the 2018 Final Rules tied up in court, plaintiffs in Texas brought a class action lawsuit challenging the Obama workaround rule, ${ }^{172}$ which requires religious nonprofits to sign opt-out paperwork and is presumably still good law. In June 2019, a federal district judge issued a

163. Religious Exemptions and Accommodations for Coverage of Certain Preventive Services Under the Affordable Care Act, 82 Fed. Reg. 47,792 (Oct. 13, 2017) (codified at 26 C.F.R. pt. 54, 29 C.F.R. 2590, and 45 C.F.R. pt. 147) [hereinafter 2017 Religious Interim Final Rule]; Moral Exemptions and Accommodations for Coverage of Certain Preventive Services Under the Affordable Care Act, 82 Fed. Reg. 47,838 (Oct. 13, 2017) (codified at 26 C.F.R. pt. 54, 29 C.F.R. 2590, and 45 C.F.R. pt. 147).

164. 2017 Religious Interim Final Rule, supra note 163.

165. Id.

166. Pennsylvania v. Trump, 281 F. Supp. 3d 553, 585 (E.D. Pa. 2017), aff'd sub nom. Pennsylvania v. President United States, 930 F.3d 543 (3d Cir. 2019), as amended (July 18, 2019), cert granted sub nom. Little Sisters of Poor v. Pennsylvania, No. 19-431, 2020 WL 254158 (U.S. Jan. 17, 2020).

167. President United States, 930 F.3d at 559 (citing Religious Exemptions and Accommodations for Coverage of Certain Preventive Services Under the Affordable Care Act, 83 Fed. Reg. 57,536 (Nov. 15, 2018) (codified at 26 C.F.R. pt. 54, 29 C.F.R. pt. 2590, and 45 C.F.R. pt. 147); Moral Exemptions and Accommodations for Coverage of Certain Preventive Services Under the Affordable Care Act, 83 Fed. Reg. 57,592 (Nov. 15, 2018) (codified at 26 C.F.R. pt. 54, 29 C.F.R. pt. 2590, and 45 C.F.R. pt. 147) [hereinafter 2018 Moral Final Rule] [collectively hereinafter 2018 Final Rules]). The 2018 Moral Final Rule gives a similar opt-out to employers with objections based on moral convictions but excludes publicly traded corporations. 2018 Moral Final Rule, supra, at 57,593.

168. 2018 Final Rules, supra note 167.

169. Trump, 351 F. Supp. 3d at 798.

170. President U.S., 930 F.3d at 556. The Third Circuit found, among other administrative law violations, that RFRA did not compel issuance of these rules. Id. at 573.

171. Little Sisters of the Poor, 2020 WL 254168, at*1.

172. DeOtte v. Azar, 393 F. Supp. 3d 490 (N.D. Tex. 2019). 
permanent nationwide injunction against the rule as a violation of RFRA. ${ }^{173}$ The injunction protects all individuals and all employers who object to contraceptive coverage based on sincerely held religious beliefs, including nonprofits and for-profits. ${ }^{174}$ This injunction produces the same result intended by the Trump administration's 2018 Final Rules: a system of wholly voluntary participation in the workaround process. ${ }^{175}$

Given the magnitude of the litigation, and the spotlight it put on conscientious refusals, HHS in January 2018 announced the establishment of the new Conscience and Religious Freedom Division to enforce twenty-five existing statutory provisions that protect the rights of conscience and religious freedom in the health care context. ${ }^{176}$ Conscience protections began shortly after abortion was legalized to ensure that no health care professional or religiously affiliated hospital that refused to perform abortions would suffer discrimination, penalty, or liability. ${ }^{177}$ Since then, Congress has passed numerous conscience laws, but they are enforced by spending restraints, not by private causes of action. ${ }^{178}$ This new HHS Division provides a grievance process for health care workers coerced or discriminated against on the basis of their refusal to participate in abortion, sterilization, training for abortion, or euthanasia. ${ }^{179}$

Entities receiving federal funding must certify compliance with all

173. Id. at 495 .

174. Id. at 497,499 .

175. See Katie Keith, ACA Litigation Round-Up: Contraceptive Coverage Mandate, HeALtH AFFAIRS (May 22, 2019), https://www.healthaffairs.org/do/10.1377/hblog20190522.119710/full/ [https://perma.cc/2DVB-TBYL] ("Under the final religious objection rule, any nonprofit or for-profit that objects to providing contraceptives for religious reasons could decline the accommodations process altogether and would no longer have to notify the government or take other steps regarding contraceptive access for employees.").

176. Press Release, U.S. Dep't of Health \& Human Servs., HHS Announces New Conscience and Religious Freedom Division (Jan. 18, 2018), https://www.hhs.gov/about/news/2018/01/18 /hhs-ocr-announces-new-conscience-and-religious-freedom-division.html [https://perma.cc/5HN5BTUK]. See Protecting Statutory Conscience Rights in Health Care; Delegation of Authority, 84 Fed. Reg. 23,170, 23,229 (May 21, 2019) (codified at 45 C.F.R. pt. 88) [hereinafter 2019 Final Rule].

177. See Mlsna, supra note 86 , at 476-82 (describing federal and state health care conscience laws).

178. Id.; see also Cenzon-DeCarlo v. Mount Sinai Hosp., 626 F.3d 695, 697-99 (2d Cir. 2010) (affirming summary judgment for a hospital and denying a nurse's claim alleging her supervisors compelled her to participate in a late-term abortion in violation of a federal conscience law because the statute did not confer a private right of action to enforce its terms).

179. Conscience Protections for Health Care Providers, U.S. DeP'T OF HEALTh \& HuMaN SERVS., https://www.hhs.gov/conscience/conscience-protections/index.html [https://perma.cc/TX7LQK58] (last reviewed Mar. 22, 2018). 
twenty-five laws. ${ }^{180}$ Nineteen states, the District of Columbia, Chicago, and New York City, have sued to enjoin these rules from going into effect, criticizing the breadth of personnel they protect and their applicability to emergency situations. ${ }^{181}$

c. The Johnson Amendment

The May 2017 executive order directed the Secretary of the Treasury to treat religious institutions with leniency in enforcing a provision of the Internal Revenue Code, known as the Johnson Amendment, that prohibits nonprofits, including religious nonprofits, from participating in political campaigns for elective office. ${ }^{182}$ The executive order did not correct any actual problem because the Internal Revenue Service already underenforces the provision, as many churches make clear their moralpolitical stand on issues, parties, and, perhaps with more subtlety, candidates. ${ }^{183}$ Whether this brings about any significant change in practice among churches remains to be seen.

2. A Narrow Establishment Clause: Religious Entities Not Required to Abandon Religion to Qualify for Government Funds and Contracts

The Guidance Document prioritizes free exercise over establishment concerns. This is the predominant conservative approach, with generous protections for religious exercise like that in Hobby Lobby alongside a narrow Establishment Clause that only reinforces the goals of free exercise. Indeed, a mere three paragraphs out of the twenty-five-page document is dedicated to the Establishment Clause, which is described only as promoting religious freedom. ${ }^{184}$ The Guidance Document makes no mention of the Clause's independent function to restrict some types of

180. 2019 Final Rule, supra note 176 , at 23,179.

181. Larry Neumeister, States Sue Over Rule Allowing Clinicians to Refuse Abortions, AP NEWS (May 21, 2019), https:/www.apnews.com/283128836a38414bb502216dd0a08be1 [https://perma.cc/ B3KV-N72Q].

182. Exec. Order No. 13,798, supra note 145, at 21,675 (citing 26 U.S.C. $\S 501(c)(3)$ (2018)).

183. See Emma Green, Why Trump's Executive Order on Religious Liberty Left Many Conservatives Dissatisfied, ATLANTIC (May 4, 2017), https://www.theatlantic.com/politics/ archive/2017/05/religious-freedom-executive-order/525354/ [https://perma.cc/4VZG-P9XN] ("[T]he administration instructed the agency to "exercise maximum enforcement discretion of the prohibition.' But that language may be misleading: The IRS already enforces the provision extremely rarely, even when pastors have mailed in tape recordings of potentially law-violating sermons in the hopes of provoking the agency.").

184. Religious Liberty Guidance Document, supra note 150, at 3, 4a. 
religious exercise. ${ }^{185}$ Liberals are more committed to defining that independent function, and now even more vehement in restricting exemptions. ${ }^{186}$

The most significant implication of a narrow reading of this Establishment Clause is that government is freer to fund and contract with religious entities. The DOJ views any religiously based disqualification from a government benefit program as discrimination and frames it within the free exercise refusal claim paradigm. ${ }^{187}$ The DOJ notes that "the denial of, or condition on the receipt of, government benefits may substantially burden" religious exercise. ${ }^{188}$ As in Sherbert v. Verner, ${ }^{189}$ the DOJ sides with religious schools and service providers who refuse to give up their religious identity in order to qualify for a government benefit or contract. ${ }^{190}$ The DOJ's stance is rooted not only in Sherbert but also quite explicitly in the recent decision of Trinity Lutheran Church v. Comer. ${ }^{191}$ In that case, Missouri's Department of Natural Resources disqualified Trinity Lutheran Church, which operates a preschool and daycare center, from receiving state grants to help defray costs of rubber playground surfaces made from recycled tires pursuant to its policy of denying grants to religious entities. ${ }^{192}$ This categorical exclusion of religious entities from the government program, the Court explained, "puts Trinity Lutheran to a choice: It may participate in an otherwise available benefit program or remain a religious institution."193 The Court held that the denial of generally available benefits to Trinity Lutheran because of its religious character violated the Free Exercise

185. See id. For a discussion of the Establishment Clause's independent function to restrict religious exercise, see Angela C. Carmella, Catholic Thought on the Common Good: A Place for Establishment Clause Limits to Religious Exercise, 15 U. ST. THOMAS L.J. 546 (2019) [hereinafter Carmella, Catholic Thought on the Common Good].

186. Carmella, Catholic Thought on the Common Good, supra note 185, at 551.

187. See Religious Liberty Guidance Document, supra note 150, at 6 ("As a general matter, the federal government may not condition receipt of a federal grant or contract on the effective relinquishment of a religious organization's hiring exemptions or attributes of its religious character.").

188. Id. at $5 \mathrm{a}$.

189. 374 U.S. 398 (1963)

190. See Religious Liberty Guidance Document, supra note 150 , at 4a ("[R]eligious adherents and organizations may, like nonreligious adherents and organizations, receive indirect financial aid through independent choice, or, in certain circumstances, direct financial aid through a secular-aid program.").

191. See id. at 3a (citing Trinity Lutheran Church of Columbia, Inc. v. Comer, 137 S. Ct. 2012 (2017)).

192. Trinity Lutheran, 137 S. Ct. at 2017

193. Id. at 2021-22. 
Clause. ${ }^{194}$ While Trinity Lutheran's scope is unclear, given that the plurality decision is explicitly limited to its facts, ${ }^{195}$ the DOJ reads the decision broadly to mean that categorical religious exclusion from a group of beneficiaries signals religious discrimination. ${ }^{196}$ The refusal claim paradigm is evident: Trinity Lutheran refused to give up its religious status in order to qualify for the state playground grant. ${ }^{197}$

\section{a. Education}

The analysis in Trinity Lutheran has been more than thirty years in the making. The Supreme Court has eroded the liberal strict separation of church and state that dominated the parochial school jurisprudence of the 1970s and 1980s and replaced it with greater tolerance for churchstate cooperation between religiously affiliated schools and government. ${ }^{198}$ Conservative plaintiffs worked hard to move the jurisprudence in the direction of inclusion of religious entities, and successfully reframed the exclusion of religious schools from benefit programs as a matter of unconstitutional discrimination under the Free Speech or Free Exercise Clause instead of an Establishment Clause demand. ${ }^{199}$ The Trump administration is pursuing this cooperation and inclusion as far as it can. Secretary of Education Betsy DeVos is committed to the public funding of nonpublic schools, including religious schools. ${ }^{200}$ She would like to see an end to state constitutional provisions, currently on the books in thirty-seven states, that prohibit public funds from reaching religious schools. ${ }^{201}$ The Supreme Court

\footnotetext{
194. Id. at 2025 .
}

195. Id. at 2024 n.3.

196. Religious Liberty Guidance Document, supra note 150, at 3a (relying on Trinity Lutheran for the proposition that "a law that disqualifies a religious person or organization from a right to compete for a public benefit-including a grant or contract—because of the person's religious character is neither neutral nor generally applicable").

197. Trinity Lutheran, 137 S. Ct. at 2017.

198. See, e.g., Widmar v. Vincent, 454 U.S. 263, 264 (1981); Rosenberger v. Rector \& Visitors of the Univ. of Va., 515 U.S. 819, 822 (1995); Locke v. Davey, 540 U.S. 712, 715 (2004); Trinity Lutheran, 137 S. Ct. at 2017.

199. See, e.g., Widmar, 454 U.S. at 264; Rosenberger, 515 U.S. at 822 ; Locke, 540 U.S. at 715 ; Trinity Lutheran, 137 S. Ct. at 2014.

200. See, e.g., Erica L. Green, DeVos Moves to Loosen Restrictions on Federal Aid to Religious Colleges, N.Y. TimES (May 9, 2018), https://www.nytimes.com/2018/05/09/us/politics/betsy-devosreligious-christian-education-federal-aid.html [https://perma.cc/M7B2-NUQA].

201. DeVos Bashes Bans on Tax Dollars in Religious Schools, United Fed’N OF TEACHERS (June 7, 2018), http://www.uft.org/news-briefs/devos-bashes-bans-tax-dollars-religious-schools [https://perma.cc/2LV2-4FX8]. 
granted certiorari on a case that could decide this issue. ${ }^{202}$

It should come as no surprise that the DOJ supports this position. In a lawsuit challenging a religious exclusion from a tuition program, the DOJ filed a statement of interest to argue that no one should be excluded from a government benefit program for religious reasons. ${ }^{203}$ Moreover, in consultation with the DOJ, DeVos announced in March 2019 that the federal government will no longer enforce a provision in federal law that disqualifies religiously affiliated contractors from providing services like special education, tutoring, or mentoring as part of the federal law's requirement that students receive equitable services. ${ }^{204}$ Districts are no longer subject to federal enforcement if they hire religious service providers. ${ }^{205}$

\section{b. Federal Contracts}

Under an August 2018 Department of Labor directive (2018 Directive), businesses and religious nonprofits likely will not lose federal contracts because their faith-based policies and practices discriminate on the basis of sexual orientation or gender identity. ${ }^{206}$ Multiple laws prohibit contractors and subcontractors from discriminating on many criteria, including sexual orientation and gender identity; at the same time, religious organizations are exempt from antidiscrimination laws when it comes to employing coreligionists and those who agree to

202. See Espinoza v. Mont. Dep't of Revenue, 435 P.3d 603 (Mont. 2018) (finding a student scholarship tax credit program unconstitutional under the Montana Constitution), cert. granted, 139 S. Ct. 2777 (2019) (mem.).

203. See United States' Statement of Interest in Support of Plaintiffs' Motion for Summary Judgment, Carson v. Makin, 401 F. Supp. 3d 207 (D. Me. 2019) (No. 1:18-CV-327-DBH), appeal filed, No. 19-1746 (1st Cir. Aug. 2, 2019).

204. Press Release, U.S. Dep't of Educ., U.S. Department of Education Finds ESEA Restriction on Religious Organizations Unconstitutional, Will No Longer Enforce (Mar. 11, 2019), https: //www.ed.gov/news/press-releases/us-department-education-finds-esea-restriction-religious-organiza tions-unconstitutional-will-no-longer-enforce [https://perma.cc/5JT5-FGF2] ("[T]he statutory provisions in Section 1117(d)(2)(B) and 8501(d)(2)(B) of the Elementary and Secondary Education Act . . run counter to the U.S. Supreme Court decision in Trinity Lutheran Church of Columbia, Inc. v. Comer that, under the Free Exercise Clause of the First Amendment of the U.S. Constitution, otherwise eligible recipients cannot be disqualified from a public benefit solely because of their religious character. Given this decision, the Department will no longer enforce these provisions ...." (citation omitted)).

205. $I d$.

206. OfFice of Fed. Contract Compliance Programs, U.S. DeP'T of Labor, Directive 2018-03, EXECUTIVE ORDER $11246 \S 204(\mathrm{C})$, RELIGIOUS EXEMPTION (2018), https://www.dol.gov/ ofccp/regs/compliance/directives/dir2018_03.html [https://perma.cc/6PTU-MPU9] [hereinafter 2018 DIRECTIVE]. 
comply with religious teachings. ${ }^{207}$ In light of Masterpiece, Trinity Lutheran, Hobby Lobby, and the Trump administration executive orders, the 2018 Directive asserts the paramount value of religious freedom and instructs compliance staffers to take these developments into account when enforcing antidiscrimination provisions. ${ }^{208}$ In summarizing relevant law on the topic, the 2018 Directive notes that the staffers must: be neutral and nonjudgmental toward religious beliefs; ${ }^{209}$ not condition contract opportunities on the recipient's abandoning their religious status, ${ }^{210}$ allow faith-based organization to "compete on a level playing field for... [Federal] contracts," 211 and respect the free exercise of religious organizations free of "discrimination or retaliation.", 12 By way of example, HHS recently decided to fund Miracle Hill Ministries in South Carolina, even though it refuses to place foster children with nonChristians or with same-sex couples. ${ }^{213}$ Recently proposed Department of Labor rules would allow religious employers with federal contracts, both nonprofits and businesses, to exclude LGBTQ persons from employment. $^{214}$

\section{RLUIPA Enforcement}

The Civil Rights Division of the DOJ continues robust enforcement of the land use provisions of RLUIPA. ${ }^{215}$ These efforts consistently

207. For instance, Title VII of the Civil Rights Act of 1964, which prohibits employment discrimination on the basis of race, color, religion, sex, or national origin, provides that religious organizations may prefer members of their religion in initial hiring decisions. 42 U.S.C. $\S 2000 \mathrm{e}-$

1(a) (2018). The Third Circuit held that this exemption protects religious employers enforcing "morals clauses." Little v. Wuerl, 929 F.2d 944 (3d Cir. 1991).

208. See 2018 DIRECTIVE, supra note 206.

209. Id. (quoting Masterpiece Cakeshop, Ltd. v. Colo. Civil Rights Comm'n, 138 S. Ct. 1719, 1731 (2018)).

210. Id. (quoting Trinity Lutheran Church v. Comer, 137 S. Ct. 2012, 2022 (2017)).

211. Id. (alteration in original) (quoting Exec. Order No. 13,831, supra note $145, \S 1$ ).

212. Id. (quoting Exec. Order No. 13,798, supra note 145, § 1).

213. Angelia Davis, Miracle Hill Gets Religious Exemptions to Provide Foster Care in SC Despite Complaints, GREENVILLE NEWS (Jan. 24, 2019), https://www.greenvilleonline.com/story /news/2019/01/23/miracle-hill-religious-protections-greenville-sc/2647848002/ [https://perma.cc/C7 9E-YGPR] (reporting that HHS granted Miracle Hill Ministries an exemption from an Obama-era restriction to continue its foster care program and noting that Miracle Hill Ministries receives $\$ 600,000$ in federal funds annually as part of its budget).

214. See Implementing Legal Requirements Regarding the Equal Opportunity Clause's Religious Exemption, 84 Fed. Reg. 41,677 (proposed on Aug. 15, 2019) (to be codified at 41 C.F.R. pt. 60). The proposed rules set out a broad exemption to allow religious employers who are federal contractors "to condition employment on acceptance of or adherence to religious tenets as understood by the employing contractor," as long as the employer did not engage in discrimination on other protected grounds, like race. $I d$. at 41,679.

215. For information on enforcement of RLUIPA's land use provisions, see Religious Freedom 
receive broad support among both conservatives and liberals, since enforcement ensures fair treatment in the zoning process to all religious groups in siting and renovating houses of worship and other religious land uses. ${ }^{216}$

\section{RELIGIOUS LiBERALS DURING THE CULTURE WARS: THE USE OF SOFT POWER}

Religious liberals reject the advertised linkage between religion and conservative causes, emphasizing instead social and economic issues ignored by traditionalists. While liberals may be interested in limiting religious exemptions in reaction to the conservative narrative, recent progressive litigants, like their conservative counterparts, may now want more robust free exercise protections to pursue their own moral agenda. ${ }^{217}$ In both theory and practice, there is a long history of advocacy for progressive causes stretching back to abolition, civil rights, and antiwar and antipoverty efforts. Public intellectuals like E.J. Dionne, ${ }^{218}$ Vincent Rougeau, ${ }^{219}$ and Steven Shiffrin ${ }^{220}$ draw on more than

in Focus Newsletters, U.S. DEP'T OF JUSTICE, https://www.justice.gov/crt/combating-religiousdiscrimination-and-protecting-religious-freedom-12 [https://perma.cc/T39Q-ZJQK].

216. For instance, the DOJ filed a statement of interest in the U.S. District Court for the District of New Jersey in support of claims brought by the Ramapough Mountain Indians (Ramapough) alleging that the Township of Mahwah, New Jersey, "violated the tribe's rights under . . [RLUIPA] by interfering with religious assembly on tribal property known as 'Sweet Water." Press Release, Dep't of Justice, Justice Department Files Statement of Interest in Religious Land Use Case Brought by Native American Group (Mar. 18, 2019), https://www.justice.gov/usao-nj/pr/justice-departmentfiles-statement-interest-religious-land-use-case-brought-native [https://perma.cc/D7UA-UC5J]. The Ramapough say this support puts them "in an uneasy alliance with a government that many of their members believe has emboldened racial animus," but, according to Chief Dwaine Perry, "are more than pleasingly surprised by the Trump administration's support" in this case. Sarah Maslin Nir, Native Americans Find Surprising Ally in N.J. Fight: Trump Administration, N.Y. Times (Apr. 22, 2019), https:/www.nytimes.com/2019/04/22/nyregion/ramapough-lenape-indians-mahwah-nj.html [https://perma.cc/PV9N-29AE].

217. Professor Steven Shiffrin argues that "religious liberals and religious conservatives share common views on the free exercise question," but the two camps differ most on Establishment Clause questions, with religious conservatives wanting a closer church-state relationship and religious liberals seeking more separation. Steven H. Shiffrin, The Religious Left and Church-State Relations: A Response to Kent Greenawalt and Bernie Meyler, 19 CORNELL J.L. \& PUB. POL'Y 761, 762-63 (2010).

218. See E.J. Dionne, JR., Souled Out: Reclaiming Faith And Politics After the RELIGIOUS RIGHT 1 (2008) ("[R]eligious faith should not be seen as leading ineluctably to conservative political convictions.”).

219. See Vincent D. Rougeau, Christians IN THE AMERICAN EMPIRE: FAith AND CITIZENSHIP IN THE NEW WORLD ORDER 19 (2008) (arguing the religious right does not have "a Christian mandate for their political agenda"). See also generally Vincent D. Rougeau, Catholic Social Teaching and Global Migration: Bridging the Paradox of Universal Human Rights and Territorial Self-Determination, 32 SEATTLE U. L. REV. 343 (2008) (arguing that secular conceptions of human dignity within liberal political theory share commonalities with Catholic Social Thought). 
a hundred years of Catholic social teachings that speak powerfully to the dignity of the human person, the stewardship of creation, and the common good. Mainline Protestant churches, with their long presence on Capitol Hill, have over a century of experience advocating for human rights and a more just economy, society, and legal system. ${ }^{221}$ Collaborative efforts over the decades between Christians and minority faiths, the Jewish community in particular, have educated lawmakers not only on minority practices but also on matters of civil liberties, equality, and social justice. ${ }^{222}$

The cacophony of the culture wars tends to overshadow religious progressive voices. But no area of law has been untouched by their witness: for fifty years they have been lobbying, protesting, and educating at the grass roots level on issues of environmental policy, ${ }^{223}$

220. See generally SHIFFRIN, supra note 22.

221. Laura R. Olson, Mainline Protestant Washington Offices and the Political Lives of Clergy, in The Quiet HAND of God: Faith-BASEd ACTIVISM AND THE Public Role of MainLine Protestantism 54, 54-56 (Robert Wuthnow \& John H. Evans eds., 2002).

222. See, e.g., Our Story, NAT'L CONFERENCE FOR CMTY. \& JUSTICE, https://www.nccj.org/ about/our-story [https://perma.cc/95YU-LCDH] (last visited Feb. 21, 2020); Wesley A. Roberts, 1963 Martin Luther King, Jr. Leads the March on Washington, CHRISTIANITY TODAY, https:/www.christianitytoday.com/history/issues/issue-28/1963-martin-luther-king-jr-leads-marchon-washington.html [https://perma.cc/DR7U-PEHC] (last visited Feb. 21, 2020).

223. Religious progressives have done important work in laying the groundwork for responses to climate change. See, e.g., NAT'L RELIGIOUS P'SHIP FOR THE ENV'T, http://www.nrpe.org/ [https://perma.cc/KBQ9-ETZW] (last visited Feb. 16, 2020); Tracy Gordon, Catholic Coalition Unveils Environmental 'Covenant,' RELIGION NEWS SERV. (Apr. 22, 2009), https:// religionnews.com/2009/04/22/catholic-coalition-unveils-environmental-covenant/ [https://perma.cc/ 3RUU-RVJ3]. In 2015, Pope Francis issued an encyclical on climate change and its effects on the environment and the poor. See Pope Francis, Encyclical Letter, Laudato Si': On Care for Our Common Home (May 24, 2015), http://w2.vatican.va/content/dam/francesco/pdf/encyclicals/ documents/papa-francesco_20150524_enciclica-laudato-si_en.pdf [https://perma.cc/X4FV-6F7E] [hereinafter Francis, Laudato Si']. In 2016, the Episcopal Church voted to divest from fossil fuel companies. Jack Jenkins, Unitarian Universalists Sue for Right to Use Solar Panels, Cite Religious Freedom, THINKPROGRESS (Aug. 3, 2016, 8:37 PM), https://thinkprogress.org/unitarian-universalists -sue-for-right-to-use-solar-panels-cite-religious-freedom-f3ef46c46efd/ [https://perma.cc/9DTQ9E7Y]. The Unitarian Universalist Association started its Green Sanctuary program in 1989 to assess their impacts and move toward sustainability in accordance with their faith. Marina Davalos, Unitarian Church of Barnstable Installs Solar Panels, BARnSTABLE PATRIOT (Mar. 7, 2018, 3:20 PM), https://www.barnstablepatriot.com/news/20180307/unitarian-church-of-barnstable-installssolar-panels [https://perma.cc/7HJ9-PTQG]. For a list of religious environmental organizations, see Russel A. Butkus \& Steven A. Kolmes, Religious Environmental Organizations, U. PORTLAND: ENVTl. SCI. \& THEOlOGY IN DiAlogue, https://sites.up.edu/envscitheobook/relig-envorganizations/ [https://perma.cc/HKX3-3SK9] (last visited Feb. 16, 2020). For a discussion of the work of religious progressives on environmental matters, see, for example, Erin Lothes Biviano, InsPired Sustainability: Planting Seeds For Action (2016); Albert C. Lin, Pope Francis', Encyclical on the Environment as Private Environmental Governance, 9 GEO. WASH. J. ENERGY \& ENVTL. L. 33, 38, 41-44 (2018) (describing regional and local church entities' plans to reduce greenhouse gases and other environmental impacts; describing how church can have positive impacts given its transnational reach); Holmes Rolston III, Saving Creation: Faith Shaping 
international human rights, ${ }^{224}$ war and torture, ${ }^{225}$ immigration, ${ }^{226}$ civil rights and racism, ${ }^{227}$ criminal justice and the death penalty, ${ }^{228}$ universal health care, ${ }^{229}$ poverty and welfare, ${ }^{230}$ human trafficking and domestic violence, ${ }^{231}$ gun control$^{232}$ and in providing sanctuary to the

Environmental Policy, 4 HARV. L. \& POL'Y REV. 121, 138-39 (2010) (noting unique contribution of Christianity to environmental policy by providing understanding of creation, humanity, and obligations of stewardship; describing faith-based environmental activities); ROGER S. GOTTLIEB, A GREENER FAith, RELigious ENVIRONMENTALISM AND OUR Planet's Future 9 (2006) (arguing religious voices are the leading voices in environmental movement); Daryl Fisher-Ogden \& Shelley Ross Saxer, World Religions and Clean Water Laws, 17 Duke EnVTL. L. \& POL'Y F. 63 (2006) (arguing religious values from the major world religions and indigenous spiritualism can inform policy choices regarding air, water, and land).

224. See, e.g., David Hollenbach, Human Rights in Catholic Thought, AM. MAG. (Oct. 31, 2005), https://www.americamagazine.org/issue/548/article/human-rights-catholic-thought [https://perma.cc/ H2HB-63TR].

225. See, e.g., Joseph J. Fahey, On Peace and War, AM. MAG. (Oct. 17, 2005), https://www.americamagazine.org/issue/546/article/peace-and-war [https://perma.cc/SY2G-5X4X]; U.S. CONFERENCE OF CATHOLIC BISHOPS, TORTURE IS A MORAL ISSUE: A CATHOLIC STUDY GUIDE (2008), http://www.usccb.org/issues-and-action/human-life-and-dignity/torture/upload/TortureIsA MoralIssueCatholicStudyGuide.pdf [https://perma.cc/7JHZ-BN6A].

226. Catholics claim an interest in family unity and human dignity: "Fencing the world out is a morally unacceptable choice." Rougeau, supra note 219 , at 358 . "Rights to emigrate and migrate are fundamental to human persons." Id. at 344. Bishops of Mexico and the U.S. collaborated on a pastoral letter, Strangers No Longer, which notes: "In the current condition of the world, in which global poverty and persecution are rampant, the presumption is that persons must migrate in order to support and protect themselves and that nations who are able to receive them should do so whenever possible." U.S. CONFERENCE OF CATHOLIC BISHOPS, STRANGERS NO LONGER ON THE JOURNEY OF Hope: A PASTORAl LetTer CONCERning Migration FROM the CATHOLIC Bishops OF MEXico AND THE UNITED STATES 39 (Jan. 22, 2003), http://www.usccb.org/issues-and-action/human-lifeand-dignity/immigration/strangers-no-longer-together-on-the-journey-of-hope.cfm [https://perma.cc/ $5 \mathrm{~K} 6 \mathrm{C}-\mathrm{CHQ}]$.

227. See, e.g., U.S. Conference of Catholic Bishops, Open Wide Our hearts: The ENDURING CALl to LOVE - A PASTORAL LeTter Against RACISM (2018), http://www.usccb.org/ issues-and-action/human-life-and-dignity/racism/upload/open-wide-our-hearts.pdf [https://perma.cc /43P9-VUXH]; Judith Rosenbaum, Clergy in the Civil Rights Movement: Introductory Essay, JEWISH WOMEN'S ARCHIVE, https://jwa.org/teach/livingthelegacy/clergy-in-civil-rights-movementintroductory-essay [https://perma.cc/2FBH-LZYL] (last visited Mar. 5, 2020).

228. See Facts \& Research: Religion, DEATH PENALTY INFO. CTR., https://deathpenaltyinfo.org/ facts-and-research/religious-statements [https://perma.cc/GYL9-H8G9] (last visited Mar. 5, 2020) (collecting information on religious efforts to end the death penalty). See, e.g., EVANGELICAL Lutheran Church in Am., A Social Statement on the Church and CRiminal Justice: HEARING THE CRIES (2013), http://download.elca.org/ELCA\%20Resource\%20Repository/Criminal_ JusticeSS.pdf [https://perma.cc/Z9CF-NGKU].

229. See, e.g., Anne Faris Rosen \& Scott Clement, Religious Groups Weigh In on Health Care Reform, PEW RES. CTR. (Oct. 8, 2009), https://www.pewforum.org/2009/10/08/religious-groupsweigh-in-on-health-care-reform/ [https://perma.cc/U5GR-5DGA] (describing the large coalition of religious groups, Faith for Health, in favor of reforms that would ensure health care for all).

230. See, e.g., Catholic Health Care, Social Services and Humanitarian Aid, U.S. CONFERENCE OF CATHOLIC BISHOPS, http://www.usccb.org/about/public-affairs/backgrounders/health-care-socialservice-humanitarian-aid.cfm [https://perma.cc/FGH5-LEDX] (last visited Mar. 5, 2020).

231. See generally Mary Graw Leary, Religious Organizations as Partners in the Global and Local Fight Against Human Trafficking, 16 REV. FAITH \& INT’L AFF. 51 (2018). 
undocumented, ${ }^{233}$ social and health services to the poor and homeless, ${ }^{234}$ substance abuse counseling, ${ }^{235}$ refugee resettlement, ${ }^{236}$ and prison reentry, ${ }^{237}$ among many other ministries. Religious liberals have also been particularly committed to the rights of religious minorities and to religious diversity and ecumenism. ${ }^{238}$ They have supported efforts to protect the LGBTQ community. ${ }^{239}$ They have been, and continue to be, present in the political and legal spheres, challenging those laws that violate their vision of the common good of society through advocacy and litigation.

Despite their considerable presence, however, religious liberals have not organized effectively as a political movement in the ways that religious conservatives have during this culture war period. A definable "religious left" emerged at the start of the Obama presidency, ${ }^{240}$ which

232. See, e.g., Gun Violence, PRESBYTERIAN MisSION AGENCY, https://www.presbyterian mission.org/what-we-believe/gun-violence/ [https://perma.cc/Y54F-RTZR] (last visited Mar. 5, 2020); Michael Sean Winters, Catholic Social Doctrine Sheds Light on How to Combat Gun Violence, NAT'L CATHOLIC REP. (Feb. 28, 2018), https://www.ncronline.org/news/opinion /distinctly-catholic/catholic-social-doctrine-sheds-light-how-combat-gun-violence [https://perma.cc/ DY5X-LRDR] ("It is shocking to me that the leaders of the pro-life community, including the U.S. bishops, are not at the forefront of this fight for stricter gun control laws. Let none of them again call anyone on the left a 'cafeteria Catholic.' You should not have to be in the womb to have your life valued ....").

233. See, e.g., Talal Ansari, Some Churches Offer Refuge from Deportation with "Sacred Resisting," WALL STREET J. (Aug. 4, 2019, 10:00 AM), https://www.wsj.com/articles/somechurches-offer-refuge-from-deportation-with-sacred-resisting-11564927200 [https://perma.cc/AJ2RSPR9].

234. See, e.g., Homelessness, Presbyterian Mission AgenCy, https://www.presbyterian mission.org/ministries/compassion-peace-justice/hunger/nationaldevelopment/homelessness/ [https ://perma.cc/F9MM-EBHF] (last visited Feb. 16, 2020).

235. See Faith Based and Community Initiatives (FBCI), SUBSTANCE ABUSE \& MENTAL HEALTH SERVS. ADMIN., https:/www.samhsa.gov/faith-based-initiatives [https://perma.cc/MTT5K9BL] (last visited Mar. 5, 2020).

236. See, e.g., Our Work with Displaced Persons, CHURCH WORLD SERV., https://cwsglobal.org/ our-work/refugees-and-immigrants/ [https://perma.cc/JJ8C-UF4V] (last visited Feb. 16, 2020); United States Resettlement Partners, U.N. REFUGEE AGENCY, https:/www.unhcr.org/en-us/usresettlement-partners.html [https://perma.cc/DFK6-6MAR] (last visited Mar. 5, 2020) (listing religious organizations that partner in refugee resettlement).

237. See generally Omar M. McRoberts, Religion, Reform, Community: Examining the Idea of Church-Based Prisoner Reentry (March 20-21, 2002) (unpublished manuscript), http://webarchive.urban.org/UploadedPDF/410802_Religion.pdf [https://perma.cc/KVH3-FRHS].

238. Many progressive and minority religious groups work together with other civil rights and human rights groups, like the Leadership Conference on Civil and Human Rights. See THE LEADERSHIP CONFERENCE ON HUMAN \& CIVIL RIGHTS, https://civilrights.org/ [https://perma.cc/72MX-VRAA] (last visited Mar. 5, 2020).

239. See, e.g., Marriage Equality and LGBTQ Rights, UNITED CHURCH OF CHRIST, https://www.ucc.org/marriage_equality_and_lgbtq_rights [https://perma.cc/K34X-7JK4] (last visited Mar. 5, 2020) (describing history of support).

240. See Daniel Burke, Re-Energized Religious Left Delivers for Obama, NAT'L CATHOLIC REP. (Nov. 6, 2008), https://www.ncronline.org/news/politics/re-energized-religious-left-delivers-obama 
gave considerable focus to progressive religious causes but was quickly overshadowed by the religious conservative outrage at the contraception mandate and other policies viewed as hostile to religion. Furthermore, the Catholic Church, with its historic emphasis on economic and social justice, has had its moral agenda torn in two. Its opposition to abortion and same-sex marriage has pulled it in closer public alignment with religious conservatives, obscuring from public view its robust commitment to just immigration policy, provision of social services, and health care reform. Its refusals to provide abortions and contraception to victims of human trafficking and to place children with same-sex couples tend to overshadow its superb work in helping those victims ${ }^{241}$ and in providing adoption services. ${ }^{242}$

\section{A. Liberal Refusal Claims: When the State Mandates Conduct Contrary to Faith}

Though refusal claims have become the mainstay of present-day religious conservatives, religious liberals have had their share of conscientious objection. The classic example is pacifist opposition to military service. Indeed, it was the involvement of many religious people in the antiwar movement of the Vietnam era that led the Supreme Court to revise the definition of religion based on theological writings and thereby expand the scope of the exemption from military service in federal law. ${ }^{243}$

The Court later added significantly to the scope of that conscientious objection to war in Thomas v. Review Board. ${ }^{244}$ In that case, Eddie Thomas, a Jehovah's Witness working at a munitions factory, was moved to a position manufacturing military tank turrets. ${ }^{245}$ Like Adele Sherbert, who was fired for refusing to take a job that required work on her Sabbath, ${ }^{246}$ Thomas was fired for refusing this position because the tank turret line involved him directly participating in the manufacture of weapons, whereas his prior job involved him only indirectly with

\footnotetext{
[https://perma.cc/UTW5-E77P].

241. See, e.g., ACLU of Mass. v. U.S. Conference of Catholic Bishops, 705 F.3d 44, 48 (1st Cir. 2013).

242. See, e.g., Fulton v. City of Philadelphia, 922 F.3d 140, 146 (3d Cir. 2019), cert. granted, No. 19-123, 2020 WL 871694 (U.S. Feb. 24, 2020) (mem.).

243. See United States v. Seeger, 380 U.S. 163, 179-80 (1965); Welsh v. United States, 398 U.S. 333, 343-44 (1970).

244. 450 U.S. 707,711 (1981).

245. Id. at 709-10.

246. Sherbert v. Verner, 374 U.S. 398, 399 (1963).
} 
manufacturing materials that may ultimately be used in weapons production. ${ }^{247}$ In his challenge to the denial of unemployment compensation, the Supreme Court found that his understanding of complicity and the line he drew, while not required or recommended by his church, was a sincerely held religious belief and deserved deference under Sherbert. ${ }^{248}$ The Court recognized that faith-based refusals to participate in war includes not only the bearing of arms but also their manufacture, and should be constitutionally protected. ${ }^{249}$

In addition to religious pacifists, those with religious scruples against participating in the death penalty can find themselves in conflict with the law. There have always been problems associated with finding someone to serve as the executioner. Throughout history, detailed protocols evolved to ensure that no one person would bear the full responsibility for the act. ${ }^{250}$ Now that executions involve professionals using advanced technology, organizations like the American Medical Association discourage participation. ${ }^{251}$ In a 2006 California case, for instance, two anesthesiologists who initially agreed to attend an execution later refused to do so when they discovered that a court order required their active participation in monitoring the prisoner for pain levels, as required by law. ${ }^{252}$

Where the death penalty is in force, extensive conscience laws protect federal and state employees and contractors who refuse to participate in executions. ${ }^{253}$ The federal protections are broad, shielding

247. Thomas, 450 U.S. at 709-11.

248. Id. at 715-16, 720 (citing Sherbert, 374 U.S. at 409-10).

249. See id.

250. Mark L. Rienzi, The Constitutional Right Not to Kill, 62 EMORY L.J. 121, 137-38 (2012). Although the federal government has not executed anyone since 2003, Attorney General William Barr in July 2019 ordered reinstatement of the federal death penalty "after a nearly two decade lapse" and directed the federal government to "schedule the executions of five death-row inmates." Press Release, Dep't of Justice, Federal Government to Resume Capital Punishment After Nearly Two Decade Lapse (July 25, 2019), https:/www.justice.gov/opa/pr/federal-government-resumecapital-punishment-after-nearly-two-decade-lapse [https://perma.cc/9Q97-A8VT].

251. See Am. Med. Ass'N, Code of Medical Ethics Opinion 9.7.3 (2017) ("[A]s a member of a profession dedicated to preserving life when there is hope of doing so, a physician must not participate in a legally authorized execution.").

252. See Rienzi, supra note 250, at 125 (citing Kevin B. O’Reilly, Controversial California Ruling Focuses on Physician Role in Execution, AM. MED. NEWS (Mar. 13, 2006), https://amednews.com/article/20060313/profession/303139966/2/ [https://perma.cc/L9M4-XZ3M]). As was the case for Eddie Thomas, their participation became "ethically unacceptable." See id. The current moratorium on the death penalty in California removes the conflict. See Brandon Sanchez, Death Penalty Opponents Applaud Sudden Moratorium in California, AM. MAG. (Mar. 13, 2019), https:/www.americamagazine.org/politics-society/2019/03/13/death-penalty-opponents-applaudsudden-moratorium-california [https://perma.cc/GG8J-2ZP5].

253. Rienzi, supra note 250 , at $139-43$. 
individuals from direct and indirect participation. ${ }^{254}$ State protections are more varied, with some allowing opt-outs without asking for any reason and others requiring a moral, ethical, or religious objection. ${ }^{255}$ Counting the states that have exemptions and those that have repealed the death penalty altogether, objectors enjoy some or total conscience protections at the federal level, in thirty-six states, and in the District of Columbia. ${ }^{256}$

Refusal claims can also arise in the context of severe immigration laws that require citizens to participate in enforcement. In 2006, the Senate considered a bill the House of Representatives passed that would have, among other things, made it a crime to serve undocumented immigrants. ${ }^{257}$ The Catholic bishops were outraged. Cardinal Roger Mahoney, then-archbishop of Los Angeles, said he would instruct his priests and lay people to defy the law if enacted. ${ }^{258}$ This set off a protest movement that energized dioceses all over the country to get involved in immigrant justice programs. ${ }^{259}$

\section{B. Liberal Affirmative Claims: When the State Restrains Conduct Motivated or Mandated by Faith}

It is not surprising that the archbishop's defiance set off a larger movement. Standing up to a state mandate of a specific act is a dramatic way of asserting religious rights. But for liberals, it has not always been the most common. Most of the progressive conflicts with government in the last fifty years involve affirmative actions that are usually lawful, but unlawful in some places or under certain circumstances. ${ }^{260}$ For instance,

254. 18 U.S.C. $\S 3597$ (2018) (providing an attendance and participation exemption for federal employees, state employees, and contractors with religious objections to the death penalty).

255. Rienzi, supra note 250 , at $140-41$.

256. Id. at 143 .

257. Border Protection, Antiterrorism, and Illegal Immigration Control Act of 2005, H.R. 4437, 109th Cong. (2005).

258. Donald Kerwin, Immigration Reform and the Catholic Church, Migration Pol'y INST. (May 1, 2006), https://www.migrationpolicy.org/article/immigration-reform-and-catholic-church [https://perma.cc/2HMU-4TQQ]. Cardinal Roger Mahoney also wrote an op-ed piece in the New York Times, arguing forcefully that "[d]enying aid to a fellow human being violates a law with a higher authority than Congress - the law of God." Roger Mahoney, Opinion, Called by God to Help, N.Y. TIMES (Mar. 22, 2006), https://www.nytimes.com/2006/03/22/opinion/called-by-god-tohelp.html [https://perma.cc/M33F-SK3V].

259. See Joel S. Fetzer, Why Did House Members Vote for H.R. 4437?, 40 InT'L MigRATION REV. 698, 698-99 (2006).

260. The roots go deep. Take, for instance, the case of Berea College in Kentucky. A state law enacted in 1904 prohibited the college, originally founded as a Christian abolitionist institution that welcomed both races during the nineteenth century, from continuing its racially integrated education. Berea Coll. v. Kentucky, 211 U.S. 45, 51 (1908). The Court upheld that law in Berea College v. Kentucky. Id. 
the antiwar Plowshares movement, begun by the Berrigan brothers in the 1980s, involved illegal trespass on military bases to protest the presence of nuclear weapons. ${ }^{261}$ Such acts differ from the refusal claims of the military conscientious objector or the death penalty physician, in which the state mandates an act.

A good example of an affirmative claim involves the pre-Obergefell practice of some liberal churches blessing or solemnizing the unions of same-sex couples. These had no legal effect, of course, but they served as a sign of religious commitment. ${ }^{262}$ When liberal states began to legalize same-sex marriage, conservative states started amending their constitutions to define marriage as exclusively between a man and woman. $^{263}$ North Carolina not only amended its constitution but also passed a companion statute that made it a crime to solemnize the marriage of a couple that did not have a valid marriage license. ${ }^{264} \mathrm{~A}$ broad coalition of churches and clergy - including the United Church of Christ, various organizations of Baptists, Lutherans, and Unitarian Universalists, the Central Conference of American Rabbis, and individual Episcopal, Jewish, and Baptist clergy — challenged the statute as an unconstitutional restriction on religious freedom, a burden on religious exercise without compelling justification. ${ }^{265}$ They sought an immediate injunction against the state law, based on a Fourth Circuit ruling that had contemporaneously barred restrictions on same-sex marriage. ${ }^{266}$ In light of that case, the federal district court found the state's ban on same-sex marriage, including the clergy restriction and penalties, unconstitutional. ${ }^{267}$ The religious claim was affirmative because the churches wanted freedom to conduct a ceremony, but the state had rendered the ceremony illegal. ${ }^{268}$ The state action was to

261. See Sharon Erickson Nepstad and Stellan Vinthagen, Strategic Changes and Cultural Adaptations: Explaining Differential Outcomes in the International Plowshares Movement, 13 INT'L J. PEACE STUDiEs 15, 16, 20-21 (2008).

262. For instance, the Unitarian Universalists have recognized same-sex unions since the mid1980s. The Unitarian Universalist Association and the Lesbian, Gay, Bisexual, \& Transgender Community (LGBT), RELIGIOUS TOLERANCE, http://www.religioustolerance.org/hom_uua.htm [https://perma.cc/CYR5-958A] (last visited Mar. 5, 2020).

263. See Same-Sex Marriage, State by State, Pew Res. Ctr. (June 26, 2015), https://www.pewforum.org/2015/06/26/same-sex-marriage-state-by-state/ [https://perma.cc/GGW5SWEY] (tracing the history of state policies on same-sex marriage).

264. See Gen. Synod of the United Church of Christ v. Resinger, 12 F. Supp. 3d 790, 791 (W.D.N.C. 2014) (finding North Carolina's ban on same-sex marriage unconstitutional).

265. Id.

266. See Plaintiffs' Memorandum of Law in Support of Their Motion for Preliminary Injunction, Resinger, 12 F. Supp. 3d 790 (No. 3:14-cv-213).

267. Resinger, 12 F. Supp. 3d at 791.

268. See Complaint at 3, Resinger, 12 F. Supp. 3d 790 (No. 3:14-cv-213) (“[Plaintiffs] ask this 
restrain, not to mandate a particular action.

The provision of sanctuary is another good example of an affirmative religious act restrained in some ways by law. ${ }^{269}$ In the 1980 s, hundreds of churches - Catholic, Methodist, Presbyterian, and Unitarian-helped refugees escaping from civil wars in El Salvador and Guatemala by providing sanctuary on their properties. ${ }^{270}$ Immigration authorities did not attempt to enter churches to make arrests, but federal agents infiltrated churches to gain information and arrest some of the leaders of the movement. ${ }^{271}$ High profile prosecutions were intended to deter church involvement, although much of the movement continued. ${ }^{272}$ The free exercise defenses to those prosecutions failed in the face of the government's compelling interest in national border security. ${ }^{273}$ Some clergy and lay people were convicted. ${ }^{274}$ Some states have passed even more draconian laws. In 2011, Alabama prohibited so many types of contact with undocumented persons that clergy sued, claiming that the law "criminalize[d] basic parts of Christian ministry."" 75

The federal government's policy evolved into less aggressive restraints over the next few decades as the sanctuary movement changed its focus. Churches involved in the "New" Sanctuary Movement, which began in the mid-2000s in reaction to the severity of proposed immigration laws, attended to protecting the many employed and productive individuals (and their families) facing deportation. ${ }^{276}$ While immigration authorities had long avoided arrests in churches, a 2011 memorandum set forth the policy: U.S. Immigration and Customs Enforcement (ICE) would not target churches, schools, and other "sensitive locations" for enforcement. ${ }^{277}$ In some cases, ICE agents even

Court to enjoin and declare unconstitutional all laws that criminalize and prohibit ceremonies or rites that recognize and bless the marriage of loving couples of the same sex.").

269. Angela C. Carmella, Land Use, in RELIGION AND THE STATE IN AMERICAN LAW 504, 54648 (2015) [hereinafter Carmella, Land Use].

270. Id. at 547 .

271. Id.

272. Id.

273. Id.

274. Id.

275. Campbell Robertson, Bishops Criticize Tough Alabama Immigration Law, N.Y. TIMES (Aug. 31, 2011), https://www.nytimes.com/2011/08/14/us/14immig.html [https://perma.cc/G9CC3AK2] ("[The Alabama law] makes it a crime to transport, harbor or rent property to people who are known to be in the country illegally, and it renders any contracts with illegal immigrants null. ... $[\mathrm{C}]$ hurch leaders ... say they will not be able to give people rides, invite them to worship services or perform marriages and baptisms ....").

276. Carmella, Land Use, supra note 269, at 548.

277. Memorandum from John Morton, Dir., U.S. Immigration \& Customs Enf't, to Field Office Dirs., Special Agents in Charge \& Chief Counsel (Oct. 24, 2011), https://www.ice.gov/doclib/ero- 
worked with clergy to find solutions. ${ }^{278}$

Perhaps the largest and most far-ranging area of affirmative acts involves the religious desire to serve the poor. Here, churches can end up in conflict with zoning laws and other local ordinances that restrain their religious conduct. ${ }^{279}$ Below are three cases-under RFRA, RLUIPA, and the Free Exercise Clause - that find that there is a conflict between religious exercise and law, with law restraining service to the poor in ways that do not serve a compelling interest in a least restrictive manner. These courts agreed with the churches' arguments that their affirmative acts in service to the poor, even in wealthy neighborhoods, were as central to their faith as worship and should not be restrained. ${ }^{280}$

In Western Presbyterian Church v. Board of Zoning Adjustment of District of Columbia, a church sued the zoning board to enjoin enforcement of an ordinance that prohibited the church from serving meals to homeless individuals at its location without a variance. ${ }^{281}$ The church won its motion for summary judgment on the grounds that enforcing the zoning ordinance would substantially burden the church's religious exercise. ${ }^{282}$ The Church argued that serving the poor is "a religious function rooted in the Bible" and "a requirement for spiritual redemption." 283 The federal district court agreed that the feeding program was religious exercise, calling it "a form of worship akin to prayer." ${ }^{284}$ Having reached this conclusion, the court explained that the First Amendment and RFRA compelled it to find in favor of the Church and held that the Church "may use its building for prayer and other religious services as a matter of right and should be able, as a matter of

outreach/pdf/10029.2-policy.pdf [https://perma.cc/W3M7-BF29].

278. Carmella, Land Use, supra note 269, at 547.

279. See, e.g., Marc-Tizoc González, Criminalizing Charity: Can First Amendment Free Exercise of Religion, RFRA, and RLUIPA Protect People Who Share Food in Public?, 7 U.C. IRVINE L. REV. 291, 295-97 (2017). See also id. at 330-31 (describing successes under state RFRAs); id. at 343 apps. 1 \& 2 (collecting cases).

280. See W. Presbyterian Church v. Bd. of Zoning Adjustment of D.C., 862 F. Supp. 538, 544 (D.D.C. 1994); Fifth Ave. Presbyterian Church v. City of New York, 293 F.3d 570, 575 (2d Cir. 2002); Harbor Missionary Church Corp. v. City of San Buenaventura, 642 F. App'x 726, 729 (9th Cir. 2016); see also World Outreach Conference Ctr. v. City of Chicago, 591 F.3d 531, 535 (7th Cir. 2009) (citing religious social service cases); City of Woodinville v. Northshore United Church of Christ, 211 P.3d 406, 411 (Wash. 2009) (finding that a city moratorium against land use permits that prevented a church from using its property as an encampment for the homeless substantially burdened the Church's religious exercise, especially since it had no alternatives).

281. 862 F. Supp. at 540.

282. Id. at 547. The court also noted that the Church's feeding program "also happen[ed] to provide, at no cost to the city, a sorely needed social service." Id. at 546.

283. Id. at 544 .

284. Id. at 547 . 
right, to use the building to minister to the needy." 285

Fifth Avenue Presbyterian Church v. City of New York involved a church that allowed homeless persons to sleep on multiple landings at the tops of staircases leading into its main sanctuary. ${ }^{286}$ After notice to the Church, New York City police entered church property to remove these guests as part of an aggressive policy to place the homeless in city shelters. ${ }^{287}$ The Church sued, arguing that it "views its outdoor space as a sanctuary for the service-resistant homeless who prefer not to sleep in shelters." 288 The Church claimed that its outdoor sanctuary "forms an integral part of its religious mission." ${ }^{289}$ Through this ministry, the Church "giv[es] the love of God .... There is perhaps no higher act of worship for a Christian." 290 The district court held that, under the Free Exercise Clause, the city burdened the Church's religious exercise and did not establish that sending the homeless to the shelters would be the least restrictive means of advancing a compelling interest that justified this burden-especially since the homeless sleeping at the Church refused to go to the shelters. ${ }^{291}$ The Second Circuit affirmed the district court's grant of a preliminary (and later permanent) injunction against the City's action. ${ }^{292}$

A final example is Harbor Missionary Church Corp. v. City of San Buenaventura, in which the Ninth Circuit held that the denial of a conditional use permit to a church to continue its homeless ministry substantially burdened the church's religious exercise in violation of RLUIPA. $^{293}$ The court found that the district court abused its discretion when it held, "without analysis," that complete denial of the permit was the least restrictive means to advance the city's compelling interest in public safety. ${ }^{294}$ The Church believed its Operation Embrace, which provided for both the spiritual and physical needs of the homeless, was part of a religious obligation to serve the poor within the physical space of the church-literally, under one roof. ${ }^{295}$ If denied a permit, the

285. Id. at 546-47. The court noted that "[z]oning boards have no role to play in telling a religious organization how it may practice its religion." Id. at 546

286. 293 F.3d 570, 572 (2d Cir. 2002).

287. Id. at $572-73$.

288. Id.

289. Id. at 574 .

290. Id. at 575.

291. Id. at 574,576 .

292. Id. at 576.

293. 642 F. App’x 726, 729-30 (9th Cir. 2016).

294. Id. at 730 .

295. Id. at 727-28. 
Church itself would have to relocate in order to provide both worship and shelter for the homeless in one location. ${ }^{296}$ The costs involved in relocating demonstrated a substantial burden on religious exercise, and the City's grant of the permit with conditions was a less restrictive alternative. ${ }^{297}$ Under the Ninth Circuit's interpretation of RLUIPA, when a church's only options impose great delays, uncertainty, and expense, a substantial burden may be found. ${ }^{298}$

While these examples involve church-owned property, service to the poor on public property is a bit trickier. Some churches have succeeded in their affirmative claims. ${ }^{299}$ Without private property, however, other religious groups tend to find themselves dependent upon the First Amendment protections given to expressive conduct on public property. Ordinances that require permits or licenses for outdoor or large group feeding must be reasonable as to time, place, and manner. ${ }^{300}$

\section{The Vulnerabilities of Liberal Affirmative Claims: The Problem of Alternatives}

These examples of affirmative acts by religious persons and entities, especially aid to the poor and to immigrants, are religiously mandated in only the most general sense: you shall love your neighbor, welcome the stranger, serve the poor, and the like. Yet the means by which these broader commands are given effect are inherently fluid, indeterminate, contextualized, and discretionary: we serve the poor in a particular way and particular time and place. But according to the Free Exercise Clause and sister statutes RFRA and RLUIPA, this indeterminacy does not make the expression or manifestation any less religious. The Free Exercise

\footnotetext{
296. Id. at 729 .
}

297. Id. at 729-30. The federal district court denied the Church's motion for a preliminary injunction, but the Ninth Circuit reversed. Id. at 730. Though the Ninth Circuit agreed that there is a compelling interest in public safety and crime prevention, it did not agree that a denial of the permit was appropriate. Id. The conditions could provide a less restrictive alternative for promoting the City's interests. See id.

298. See id. at 729-30.

299. See, e.g., Chosen 300 Ministries, Inc. v. City of Philadelphia, No. 12-3159, 2012 WL 3235317 , at $* 18, * 27$ (E.D. Pa. Aug. 9, 2012) (granting a preliminary injunction based on state RFRA against a city policy prohibiting food-sharing with the homeless on 9,200 acres of public parks, noting churches had long engaged in this "religious practice").

300. Compare Santa Monica Food Not Bombs v. City of Santa Monica, 450 F.3d 1022, 1029-30 (9th Cir. 2006) (giving considerable First Amendment protection as to narrow tailoring to a city ordinance, which was amended in the course of litigation to allow noncommercial food distribution without permit or license), with First Vagabonds Church of God v. City of Orlando, 638 F.3d 756, 761-62 (11th Cir. 2011) (holding an ordinance requiring a permit for a "large group feeding" was a reasonable time, place, and manner restriction). 
Clause has never been interpreted to limit protection only to "mandatory" religious practices. ${ }^{301}$ Both RFRA and RLUIPA define religious exercise capaciously to include "any exercise of religion, whether or not compelled by, or central to, a system of religious belief." 302 Congress provides that this concept "shall be construed in favor of a broad protection of religious exercise, to the maximum extent permitted by the terms of this chapter and the Constitution."303 Indeed, the current Free Exercise climate has never been more protective of religious claimants. The Supreme Court demands respect and equitable treatment for religious practice and identity. ${ }^{304}$ It applies RFRA and RLUIPA strict scrutiny in remarkably robust ways. ${ }^{305}$ Moreover, while Smith's rational basis standard continues to govern where constitutional or statutory strict scrutiny is not available, more than half of the states require strict scrutiny for religious claims by way of their own statutes or constitutions. $^{306}$

From the cumulative interpretations of Gonzales, Hobby Lobby, and Holt, the Court has concluded that both RFRA and RLUIPA create an exemption-friendly jurisprudence. The statutes "contemplate[] a 'more focused' inquiry and 'require[] the Government to demonstrate that the compelling interest test is satisfied through application of the challenged law 'to the person'- the particular claimant whose sincere exercise of religion is being substantially burdened." ${ }^{, 307}$ These statutes require courts to " scrutiniz[e] the asserted harm of granting specific exemptions to particular religious claimants' and 'to look to the marginal interest in enforcing' the challenged government action in that particular context." ${ }^{308}$ The upshot is that the government is required "not merely to

301. See, e.g., Thomas v. Review Bd., 450 U.S. 707, 714 (1981) ("The determination of what is a 'religious' belief or practice . . . is not to turn upon a judicial perception of the particular belief or practice in question; religious beliefs need not be acceptable, logical, consistent, or comprehensible to others in order to merit First Amendment protection.").

302. 42 U.S.C. $§ 2000 c c-5(7)(A)$ (2018). RFRA imports RLUIPA's definition: "The term 'exercise of religion' means religious exercise, as defined in Sec. 2000cc-5 of this title." Id. $\S$ 2000bb-2(4).

303. Id. $\S 2000 \mathrm{cc}-3(\mathrm{~g})$.

304. See, e.g., Trinity Lutheran Church v. Comer, 137 S. Ct. 2012, 2017-18, 2024 (2017); Masterpiece Cakeshop, Ltd. v. Colo. Civil Rights Comm'n, 138 S. Ct. 1719, 1731-32 (2018).

305. See, e.g., Burwell v. Hobby Lobby Stores, Inc., 573 U.S. 682, 707-08 (2014); Holt v. Hobbs, 574 U.S. 352, 369 (2015).

306. See Juliet Eilperin, 31 States Have Heightened Religious Freedom Protections, WASH. POST (Mar. 1, 2014, 1:13 PM), https://www.washingtonpost.com/news/the-fix/wp/2014/03/01/where-inthe-u-s-are-there-heightened-protections-for-religious-freedom/ [https://perma.cc/4TNL-447H] (depicting a map of U.S. states with heightened religious freedom protections).

307. Holt, 574 U.S. at 362 (quoting Hobby Lobby, 573 U.S. at 726).

308. Id. at 363 (quoting Hobby Lobby, 573 U.S. at 726-27). 
explain why it denied the exemption but to prove that denying the exemption is the least restrictive means of furthering a compelling governmental interest." ${ }^{309}$ In other words, the Court has assigned an onerous task to the government in the strict scrutiny analysis.

At the same time, the Court has made establishing a substantial burden fairly straightforward. In Hobby Lobby, the Court was clear that the rule requiring plaintiffs to engage in conduct they found objectionable, together with the costs associated with a refusal to comply - hundreds of millions of dollars in fines - created a substantial burden. ${ }^{310}$ As to the argument that the religious beliefs of complicity in sinful behavior were too attenuated to be cognizable, the Court said it could not engage in a theological analysis. ${ }^{311}$ A sincerely held belief that results in severe penalties is sufficient to establish a substantial burden under RFRA. ${ }^{312}$

Though Hobby Lobby announced a more lenient approach to establishing a substantial burden, the judicial "substantial-burden skeptics," as Professor Michael Helfand calls them, ${ }^{313}$ continue to set a high bar and place obstacles in the way. Since the 1960s, the substantial burden prong of strict scrutiny has been a powerful gatekeeper, preventing many claims from ever triggering analysis of the government's interest. ${ }^{314}$ Indeed, the skeptics continue to view the substantial burden prong as a formidable hurdle to overcome, as they inquire warily "whether claimants seeking religious accommodations have truly experienced a substantial burden on their religious exercise." 315

It is easier to establish a substantial burden with a refusal claim than an affirmative claim. ${ }^{316}$ Conservative religious actors refuse to obey government requirements: to perform or pay for an abortion, to provide gender confirmation surgery, to retain a transgender employee, to dispense emergency contraception, to place a foster child with a same-

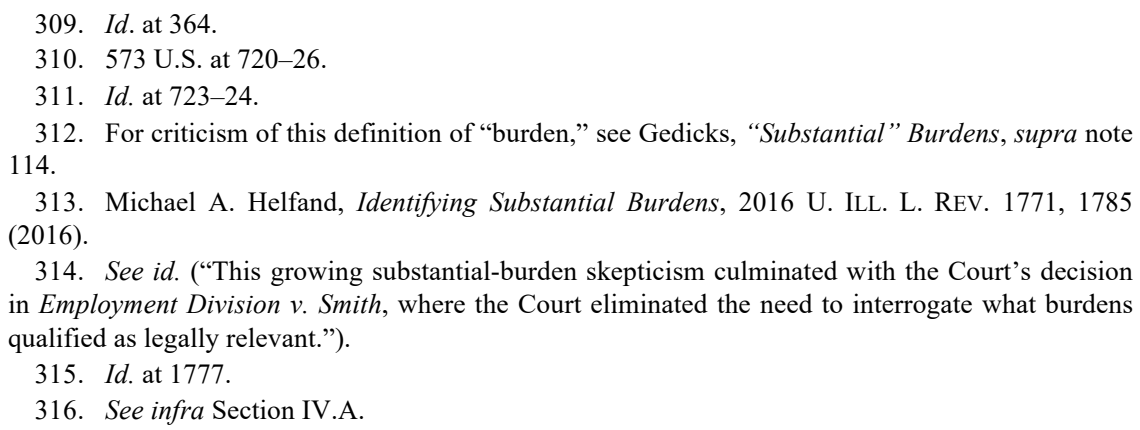

314. See id. ("This growing substantial-burden skepticism culminated with the Court's decision in Employment Division v. Smith, where the Court eliminated the need to interrogate what burdens qualified as legally relevant.").

315. Id. at 1777 .

316. See infra Section IV.A. 
sex couple, to bake a wedding cake or arrange flowers for a same-sex wedding, to sign the marriage certificate, to give up one's beliefs or identity to qualify for a government benefit. The refusal itself triggers a legal penalty. Such direct coercive pressure of being forced to act against one's religion, typically under threat of severe penalty, is easily seen as burdensome.

Of course, refusal claimants do not always win, but there is a certain rhetorical power to the image of the state compelling a person to act against conscience or deeply held convictions. It is no surprise that the free exercise success stories pre- and post-culture wars tended to involve refusal claims: the Amish families who refused to send their children to school; ${ }^{317}$ Adele Sherbert ${ }^{318}$ and Eddie Thomas, ${ }^{319}$ who refused to compromise their religious beliefs to obtain government benefits; the Hahn family and the Green family, who refused to provide employee insurance coverage for contraceptives they believe are abortifacients; ${ }^{320}$ and Abdul Maalik Muhammad, who refused to shave his beard. ${ }^{321}$

In my view, it is harder to establish a substantial burden for affirmative claims. Affirmative claims, the current vehicle of progressive religious exercise on poverty, immigration, and the environment, all require broad latitude to be free from legal restraint. But judicial skeptics view with suspicion the claim that one must, as a matter of religious conviction, provide sanctuary to the undocumented, feed and shelter the poor in church, or use property in a way that reduces the carbon footprint. Some skeptics inquire whether the claim is political or philosophical, not religious. ${ }^{322}$ Questions like this emerge even though the Court has repeated for nearly forty years that "religious beliefs need not be acceptable, logical, consistent, or comprehensible to others," ${ }^{323}$ and the plausibility or reasonableness of a religious claim may not be investigated. ${ }^{324}$

Most significantly, substantial-burden skeptics ask whether the

317. Wisconsin v. Yoder, 406 U.S. 205, 207 (1972).

318. Sherbert v. Verner, 374 U.S. 398, 399 (1963).

319. Thomas v. Review Bd., 450 U.S. 707, 711 (1981).

320. Burwell v. Hobby Lobby Stores, Inc., 573 U.S. 682, 700-02 (2014).

321. Holt v. Hobbs, 574 U.S. 352, 355 (2015).

322. See, e.g., Stephanie Acosta Inks, Immigration Law's Looming RFRA Problem Can Be Solved by RFRA, 2019 BYU L. REV. 107, 121-24 (noting how sometimes sanctuary is viewed not as religious but as disagreement with government policy).

323. Thomas, 450 U.S. at 714.

324. Hobby Lobby, 573 U.S. at 724; see also Gedicks, "Substantial" Burdens, supra note 114, at 115-17 (noting courts are not permitted to address the "religious question" and must instead use neutral principles). 
religious claimant has alternatives. This concern renders affirmative (and therefore liberal) claims vulnerable because countless interactions between law and religious exercise offer myriad ways to serve the poor, help the immigrant, and protect the environment. Why do it this way and not another? Did the law truly create a burden, or did the religious actors have options that fell within the bounds of the law? ${ }^{325}$ Are the conflicts of their own making? As Professor Helfand has written in a different context, but relevant for this point:

A law imposes a substantial burden because it leaves the aggrieved party with limited options for engaging in religious exercise. In a case of a substantial burden, the only option that remains to engage in religious exercise is to incur some sort of significant civil sanction, tax, or penalty. And in leaving only such an option, the law has thereby imposed a substantial burden that is triggered by religious exercise. ${ }^{326}$

If the very definition of burden relies on being trapped by law or government policy with no way out, then many affirmative claims will not make the cut. These claims seek to protect decisions regarding the means by which broad religious commands are given effect-decisions that may emerge from an indeterminate, fluid, contextualized, and discretionary process.

The affirmative claimant makes a decision to manifest her faith in a particular way. Once that decision - an inherently religious act-is made, a court should be bound to ask whether the law that restrains that act of faith substantially burdens her religious exercise. Instead, substantial-burden skeptics ask whether any options existed in the first instance -indeed, whether the claimant was under an inescapable compulsion to make the decision she made. ${ }^{327}$ By way of example, consider the prosecutions of clergy and other church members during the 1980s Sanctuary Movement. Accused of felony transportation of

325. See, e.g., United States v. Epstein, 91 F. Supp. 3d 573, 581 (D.N.J. 2015) ("One way to qualitatively assess the burden that a government practice places on religious exercise is to consider whether an adherent has acceptable alternative means to practice his religion."); Oklevueha Native Am. Church of Haw., Inc. v. Lynch, 828 F.3d 1012, 1017 (9th Cir. 2016) ("[Plaintiffs] have produced no evidence that denying [Native Americans] cannabis forces them to choose between religious obedience and government sanction, since they have stated in no uncertain terms that many other substances including peyote are capable of serving the exact same religious function as cannabis.").

326. Helfand, supra note 313 , at 1805 (emphasis added).

327. To establish a substantial burden, some courts require the claimant to show that the law requires what is forbidden or forbids what is required, even though Supreme Court jurisprudence and the statutory text of RFRA and RLUIPA explicitly consider it possible to substantially burden religious exercise that is not central to or mandated by religion. 
undocumented persons, these sanctuary workers claimed a free exercise defense. ${ }^{328}$ Courts would not find a burden where legal alternatives were available:

Representatives of Catholic and Methodist clergy testified at the pretrial hearing and at trial. None suggested that devout Christian belief mandates participation in the "sanctuary movement." Obviously, appellants could have assisted beleaguered El Salvadorans in many ways which did not affront the border control laws: they could have collected and distributed monetary and other donations, aided in preparing petitions for legal entry and assisted El Salvadorans legally in this country, or, in the Christian missionary tradition, they could have performed their ministry in El Salvador or neighboring countries where El Salvadorans are refugees. They chose confrontational, illegal means to practice their religious views - the "burden" was voluntarily assumed and not imposed on them by the government. ${ }^{329}$

Similarly, in the land use context, courts have found that alternatives vitiate the existence of a burden. In pre-RLUIPA zoning cases, the existence of possible "alternative locations"-areas in the municipality with more hospitable zoning - was typically fatal to a church's claim. ${ }^{330}$ Imagine a court saying that Western Presbyterian Church or First Presbyterian Church had lots of options for serving the poor in other parts of town that did not involve bringing homeless individuals to affluent neighborhoods: they could have sheltered them elsewhere, or even collected money to help. One need not go far to find such cases. In Daytona Rescue Mission, Inc. v. City of Dayton Beach ${ }^{331}$ and in First Assembly of God of Naples, Florida, Inc. v. Collier County, Florida, ${ }^{332}$ courts upheld denials of permission to serve the homeless because the churches could (at least theoretically) operate these ministries in other parts of the municipality. And today, even with RLUIPA's express intent to provide generous and robust protection of religious land use,

328. See United States v. Merkt, 794 F.2d 950, 954 (5th Cir. 1986); United States v. Elder, 601 F. Supp. 1574, 1577 (S.D. Tex. 1985).

329. Merkt, 794 F.2d at 956 (emphasis added); see also Elder, 601 F. Supp. at 1580 ("“ $[\mathrm{N}]$ othing in this decision prohibits the exercise of Christian charity to those who present themselves before the [U.S. Immigration and Naturalization Services (INS)] to apply for asylum and who proceed under INS rules." (citing United States v. Pereira-Pineda, 721 F.2d 137 (5th Cir.1983)).

330. See Angela C. Carmella, RLUIPA: Linking Religion, Land Use, Ownership and the Common Good, 2 AlB. Gov'T L. REV. 485, $493-94$ (2009).

331. 885 F. Supp. 1554, 1560 (M.D. Fla. 1995) (finding no substantial burden because the Church failed to show the city code prohibited homeless shelters from all zones in the City of Dayton).

332. 20 F.3d 419, 423 (11th Cir. 1994) (finding the ordinance at issue facially neutral because it defined areas where shelters could operate). 
some courts still require claimants to demonstrate a lack of acceptable alternative properties. ${ }^{333}$

One might be tempted to argue that the Supreme Court recently abandoned the reliance on the "alternatives," so even if once common, this consideration will disappear in time. It is true that the Court has spoken negatively about alternatives as a basis for discussing free exercise claims. First, the Court in Burwell v. Hobby Lobby Stores, Inc. considered the argument that the employers could avoid the burden on their beliefs simply by not providing any health insurance to employees. ${ }^{334}$ The Court found that even this alternative created a substantial burden under RFRA because of severe financial penalties and disadvantage in the employee marketplace. ${ }^{335}$ A year later, in Holt $v$. Hobbs, the Court considered the notion of alternatives more directly under RLUIPA. ${ }^{336}$ In that case, Muslim prisoner Muhammad refused to shave his beard as required by the prison's grooming policy, but he offered to keep his beard to a half-inch. ${ }^{337}$ The Court found that the lower court erred when it concluded that the prison's grooming policy did not substantially burden Muhammad's religious exercise because "he had been provided a prayer rug and a list of distributors of Islamic material, he was allowed to correspond with a religious advisor, and was allowed to maintain the required diet and observe religious holidays." 338 The Court clarified that "RLUIPA's 'substantial burden' inquiry asks whether the government has substantially burdened religious exercise (here, the growing of a [half]-inch beard), not whether the RLUIPA claimant is able to engage in other forms of religious exercise." 339

But these recent Supreme Court statements, made in the context of refusal claims, do not directly address the issue of alternatives as they

333. Carmella, Land Use, supra note 269, at 520-21. Some courts take available alternative locations into account, but others do not. Id.; Lisa Mathews, Hobby Lobby and Hobbs to the Rescue: Clarifying RLUIPA's Confusing Substantial Burden Test for Land-Use Cases, 24 GEO. MASON L. REV. 1025, 1041 (2017) (noting "broad disagreement" among courts on the significance of "availability of other land"). See, e.g., San Jose Christian Coll. v. City of Morgan Hill, 360 F.3d 1024, 1035 (9th Cir. 2004) (finding the city regulations at issue did not "render religious exercise effectively impracticable" because, inter alia, the record contained no evidence demonstrating the college was "precluded from using other sites within the city"). Churches that get approval for some part, but not all, of their affirmative claims, or receive conditional approval, may have difficulty establishing a burden. Carmella, Land Use, supra note 269, at 520-21.

334. 73 U.S. 682, 720-23 (2014). Neither party raised this issue, but the Court still chose to address it. See id.

335. Id. at 722-23.

336. 574 U.S. 352, 361-62 (2015).

337. Id. at 352 .

338. Id. at 361 .

339. Id. at 361-62. 
arise in the context of progressive affirmative claims. In Hobby Lobby, the Court still considered the alternative, and then rejected it because it generated severe burdens of its own. ${ }^{340}$ This suggests that a tolerable alternative might have been persuasive, even in a refusal context. Moreover, Holt is forged in the prison context, where prisoners are dependent upon prison administrators for every aspect of religious exercise. The Court made clear that a prison, given the highly controlled setting, cannot say that the prisoner has had enough religious exercise by accommodating some but not other practices. ${ }^{341}$ Even skeptical courts have not told religious liberals that worship and prayer are enough; rather, these courts ask whether the affirmative act can take alternative forms or be accomplished in alternative locations so as not to conflict with law. ${ }^{342}$ The discussions of alternatives in Hobby Lobby and Holt do not speak to the issue of the indeterminacy and fluidity of affirmative claims. Nevertheless, Thomas, and its application in Hobby Lobby and Holt, arguably continues to provide a powerful example against the argument that alternatives necessarily undermine the burden. In those cases, the Court readily deferred to the religious claimant's judgment about what faith required, which works for the progressive claimant just as it does for the traditionalist one.

Yet even with such judicial deference, the work of a new wave of judicial skeptics trying to narrow federal statutes $^{343}$ can render affirmative claims vulnerable to the great variety of "substantial burden" approaches across the federal courts of appeals as well as state courts. Because RFRA and RLUIPA do not explicitly define what constitutes a substantial burden, circuits have been open to multiple interpretations, which range from quite lenient to nearly impossible to establish. ${ }^{344}$ Some require a showing that religious exercise is "effectively impracticable." 345

\footnotetext{
340. See 573 U.S. at $720-23$.

341. See Holt, 574 U.S. at 361.

342. See supra notes 313-33 and accompanying text.

343. See Helfand, supra note 313, at 1785 (explaining that substantial-burden skepticism has led "many federal courts" to interpret "RFRA's provisions that limited the category of what qualified as a substantial burden" in a way that defines a "substantial burden" as one that "implicate[s] central tenants of the claimant's faith" or that "compel[s] conduct that violate[s] a claimant's faith").

344. See Mathews, supra note 333, at 1036-42 (explaining the differing approaches the federal circuit courts have utilized in determining what constitutes a "substantial burden"); see also Rodrigo L. Silva, Reckoning RLUIPA's Substantial Burden Provision, 8 J. MARSHALL L.J. 127, 142-49 (2014) (explaining that the circuit courts tend to use one of three approaches: narrowly defining "substantial burden," requiring "more than an inconvenience on religious exercise," or broadly defining "substantial burden").

345. Carmella, Land Use, supra note 269, at 516 (quoting Civil Liberties for Urban Believers v. City of Chicago, 342 F.3d 752, 761 (7th Cir. 2003)).
} 
Others say a claimant must demonstrate that the law imposes a "significantly great restriction." 346 Some require a showing of "significant pressure which directly coerces the [claimants] to conform [their conduct to the law]." ${ }^{347}$ Others use a multi-factor test. ${ }^{348}$ And for all of these, the decisions are sensitive to specific facts. ${ }^{349}$ Indeed, the definition of substantial burden can be so restrictive as to exclude

346. Id. at 517 (quoting Guru Nanak Sikh Soc'y v. County of Sutter, 456 F.3d 978, 988 (9th Cir. 2006)).

347. Id. (quoting Midrash Sephardi, Inc. v. Town of Surfside, 366 F.3d 1214, 1227 (11th Cir. 2004)).

348. See id. (explaining that in Roman Catholic Bishop, the First Circuit "identif[ied] some relevant factors" to find a substantial burden including "whether the regulation is arbitrary, capricious, or unlawful or targets religious practices or groups in a hostile way and whether the process, though facially neutral, will necessarily produce a negative result for the religious applicant." (citing Roman Catholic Bishop v. City of Springfield, 724 F.3d 78, 96-97 (1st Cir. 2013))); The Tenth Circuit applied a different set of factors:

[A] government act imposes a "substantial burden" on religious exercise if it: (1)

"requires participation in an activity prohibited by a sincerely held religious belief," (2)

"prevents participation in conduct motivated by a sincerely held religious belief," or (3)

"places substantial pressure on an adherent... to engage in conduct contrary to a sincerely held religious belief."

Hobby Lobby Stores, Inc. v. Sebelius, 723 F.3d 1114, 1138 (10th Cir. 2013) (quoting Abdulhaseeb v. Calbone, 600 F.3d 1301, 1315 (10th Cir. 2010)), aff'd sub nom. Burwell v. Hobby Lobby Stores, Inc., 573 U.S. 682 (2014). The Third Circuit found that a substantial burden exists if:

(1) "[A] follower is forced to choose between following the precepts of his religion and forfeiting benefits otherwise generally available to other[s] . . versus abandoning one of the precepts of his religion in order to receive a benefit;" or (2) "the government puts substantial pressure on an adherent to substantially modify his behavior and to violate his beliefs."

Mack v. Warden Loretto FCI, 839 F.3d 286, 304 (3d Cir. 2016) (quoting Washington v. Klem, 497 F.3d 272, 280 (3d Cir. 2007)). As Lyng said, there is no need for direct coercion; "indirect coercion or penalties on the free exercise of religion, not just outright prohibitions, are subject to scrutiny." Lyng v. Nw. Indian Cemetery Protective Ass'n, 485 U.S. 439, 450 (1988). The Ninth Circuit noted that "[u]nder RFRA, a 'substantial burden' is imposed only when individuals are forced to choose between following the tenets of their religion and receiving a governmental benefit (Sherbert) or coerced to act contrary to their religious beliefs by the threat of civil or criminal sanctions (Yoder)." Navajo Nation v. U.S. Forest Serv., 535 F.3d 1058, 1069-70 (9th Cir. 2008).

349. Carmella, Land Use, supra note 269, at 519. Courts typically use an objective standard for the question of law on what constitutes a substantial burden, although on occasion a court defers to the claimant's subjective determination. See, e.g., World Outreach Conference Ctr. v. City of Chicago, 591 F.3d 531, 539 (7th Cir. 2009) (assuming that "whether a burden is substantial" is a question of fact and that "substantiality is a relative term - whether a given burden is substantial depends on its magnitude in relation to the needs and resources of the religious organization in question"). In certain circumstances, affirmative claims may not even be cognizable as, for example, when a claimant points to the government penalty itself as the source of the burden. See Tyms-Bey v. State, 69 N.E.3d 488, 491 (Ind. Ct. App. 2017) (“[T]he relevant 'means,' for purposes of RFRA, is the 'burden' the party hopes to avoid, not the sanction imposed for ignoring that burden."). The substantial burden must be separate from the particular type of enforcement. For instance, the requirement to pay taxes might burden one's religion, not the fines or imprisonment for failing to pay them. Id. Further, a less restrictive alternative must accommodate the religious practice, not lessen severity of the restriction. See id. (citing United States v. Christie, 825 F.3d 1048, 1061-62 (9th Cir. 2016)). 
"[m]any of the very situations that Congress intended to include within the statutes' reach." 350

\section{Another Vulnerability: Unrecognized Claims Due to Lack of Coercion}

Some religious claims, even those that involve severe impacts on religion, are not cognizable in court. Courts require coercion as a threshold for constitutional and statutory free exercise claims. ${ }^{351}$ Refusal claims and most affirmative claims meet this requirement. But affirmative claims of Native Americans often do not.

The religious practices of Native American tribes are protected, if at all, by a complex web of treaty, constitutional, and statutory laws. ${ }^{352}$ Though it is difficult to generalize the religious practices of numerous individual tribes, it is safe to say that their religious claims arise most commonly in one of two ways: either to allow ceremonial practices or to protect sacred lands. As to ceremonial practices, federal statutes exempt members of the Native American Church who ingest the illegal drug peyote as a sacrament ${ }^{353}$ and permit the taking of bald eagles and their feathers, which is otherwise unlawful, for ritual purposes. ${ }^{354}$

As to federally owned lands, like national park lands, trust lands, and sacred sites, Native Americans enjoy access. But if a tribe claims that a particular government program makes it harder for it to practice its religion, it has not met the coercion requirement. ${ }^{355}$ In Lyng v. Northwest Indian Cemetery Protective Ass' $n$, the Supreme Court denied a claim for protection from a paved road and timber foresting on sacred lands. ${ }^{356}$ The tribes argued that "disruption of the natural environment... will diminish the sacredness of the area in question" and impair their

350. Brief of Amici Curiae Religious Liberty Law Scholars in Support of Petition for a Writ of Certiorari at 10, Navajo Nation v. U.S. Forest Serv., 556 U.S. 1281 (2009) (No. 08-846), 2009 WL 318196 [hereinafter Brief of Religious Liberty Law Scholars].

351. See, e.g., Sch. Dist. of Abington Twp. v. Schempp, 374 U.S. 203, 223 (1963) (“[A] violation of the Free Exercise Clause is predicated on coercion . . ..").

352. See Religious Liberty Guidance Document, supra note 150, at 17a.

353. 42 U.S.C. $\S 1996 a(2018)$.

354. 16 U.S.C. $\S 668$ a (2018).

355. See Lyng v. Nw. Indian Cemetery Protective Ass'n, 485 U.S. 439, 450-51 (1988) ("[I]ndirect coercion or penalties on the free exercise of religion . . . are subject to scrutiny under the First Amendment... This does not and cannot imply that incidental effects of government programs, which may make it more difficult to practice certain religions but which have no tendency to coerce individuals into acting contrary to their religious beliefs, require government to bring forward a compelling justification for its otherwise lawful actions.").

356. Id. at 453 . 
religious practices. ${ }^{357}$ Although the tribes experienced these impacts as severe restraints on religious practices, the Court denied the claim, holding that government coercion must exist for there to be a constitutionally cognizable burden to religious exercise. ${ }^{358}$ Here, the government conceded the possibility of "devastating effects on traditional Indian religious practices." 359 Nevertheless, the Court decided that no burden could be found because the government's action did not coerce anyone "into violating their religious beliefs" or "penalize religious activity by denying any person an equal share of the rights, benefits, and privileges enjoyed by other citizens." 360 The Court reasoned that access to sacred sites on federal lands is sufficient; the government has no responsibility to ensure the quality of religious experience. ${ }^{361}$ Government must mandate, prohibit, or penalize religious exercise as a prerequisite to demonstrating a burden on religious exercise. ${ }^{362}$

One can understand this threshold inquiry in the context of Western faiths. Imagine religiously conservative parents arguing that the existence of same-sex married couples makes it harder to raise children in a wholesome, faith-filled environment, or a religiously liberal business owner arguing that lax federal pollution levels are immoral and place her business at an economic disadvantage because she follows stricter limits. No court would entertain the free exercise claims of those parents or that business owner. ${ }^{363}$ These impacts are byproducts of legislation and regulation. In the context of land-based faiths, however, the coercion requirement makes it nearly impossible to seek free exercise protection even from severe religious impairment caused directly by government

\footnotetext{
357. Id. at 448 .

358. Id. at $450-51$.

359. Id. at 451 .

360. Id. at 449 .

361. See id. at $451-52$.

362. See id. at 459 (Brennan, J., dissenting) (explaining the majority's position "that federal land-use decisions that render the practice of a given religion impossible do not burden that religion in a manner cognizable under the Free Exercise Clause, because such decisions neither coerce conduct inconsistent with religious belief nor penalize religious activity"). Some have argued that RFRA's passage affected Lyng's continued relevance. See, e.g., Navajo Nation v. U.S. Forest Serv., 535 F.3d 1058, 1090 (9th Cir. 2008) (Fletcher, J., dissenting).

363. The argument was made and rejected in parochial school funding cases that the use of tax revenues to subsidize secular activities of religious schools violated the Free Exercise Clause. See, e.g., Tilton v. Richardson, 403 U.S. 672, 674-77, 689 (1971) (holding that grants given to parochial colleges to construct new facilities did not violate the Free Exercise Clause because the funds were used for secular purposes). The Court was "unable to identify any coercion directed at the practice or exercise of their religious beliefs." Id. at 689 .
} 
land management programs. ${ }^{364}$ Many federal statutes require upfront consideration of the cultural and religious needs of native peoples, ${ }^{365}$ but these tend to be ineffective in avoiding religious harms. Justice Brennan's approach, set out in his Lyng dissent, provided an obvious answer: government action that "frustrates or inhibits religious practice" passes the threshold for coercion. ${ }^{366}$

\section{RELIGIOUS LIBERALS IN THE TRUMP ERA: THE USE OF LITIGATION}

As noted in the previous section, religious liberals have been actively involved in lobbying and litigation for the past fifty years, with increasing frequency. Indeed, even on the eve of Trump's election, it was noted:

$[\mathrm{P}]$ rogressives are now leveraging the First Amendment principle as a vehicle to advance causes of their own. As they see it, social action is integral to living out their faith, and local ordinances can't take away their rights. In the name of religious freedom, activists are defying local resistance to their campaigns for social change. They're pressing ahead, for instance, with plans to install solar panels over a local board's objections in Massachusetts and to establish tent cities for the homeless in California and Michigan. ${ }^{367}$

Since the 2016 election, however, some progressive religious causes have become even more prominent as a direct result of Trump's policies, particularly those dealing with the immigration crisis. ${ }^{368}$

364. See Helfand, supra note 313, at 1805. Professor Helfand says the Lyng Court should have found a substantial burden:

Instead of providing an option to engage in religious exercise and then endure a significant sanction, tax or penalty, the law refuses even that option. And in so doing, such laws - whether they be building a road or shaving an inmate-ought to be understood as constituting a substantial burden. What those laws have done is leave a person in a position that is even worse than enduring a substantial burden; they are actually coercing a person's failure to engage in religious exercise.

Id.

365. Connie Rogers, Native American Consultation in Resource Development on Federal Lands, Colo. LAw., Jan. 2002, at 113, 113.

366. Lyng, 485 U.S. at 459 (Brennan, J., dissenting). The dissent argued that the constitutional guarantee of free exercise "is directed against any form of governmental action that frustrates or inhibits religious practice." $I d$.

367. Lauren Markoe, Progressives Embrace Religious Liberty for Their Own Causes, RELIGION NEWS SERV. (Aug. 26, 2016), https://religionnews.com/2016/08/26/progressives-embrace-religiousliberty-for-their-own-causes/ [https://perma.cc/VAC8-2U9W].

368. Daniel Bush, Religious Liberals Want to Change What It Means to Be a Christian Voter, PBS (July 8, 2019, 5:27 PM), https://www.pbs.org/newshour/politics/religious-liberals-want-tochange-what-it-means-to-be-a-christian-voter [https://perma.cc/Z4Z2-93JZ] (noting that "[m]any progressives credited Trump for pushing more liberal religious leaders to speak up" for causes such 
As a general matter, religious liberals do not have a coordinated strategy, nor do they have religious liberty law firms to represent their causes. But think tanks and law professors have become involved in some recent litigation, ${ }^{369}$ which may signal a move toward a more comprehensive approach. Indeed, some religious liberals and legal scholars thinking strategically about religious freedom in the Trump era may attempt to mirror the successes of conservative free exercise claims by bringing or defending lawsuits that seek religious exemptions for progressive causes. Several scholars contend that RFRA could provide a strong argument for the protection of sanctuary churches, based upon cases like Gonzales, Hobby Lobby, and Holt, which have dramatically altered the legal landscape in favor of religious claimants. ${ }^{370}$ Another scholar notes that RFRA could provide support for Native American land-based claims because Hobby Lobby explicitly held that RFRA broke free from the pre-Smith jurisprudence, which "clearly opens the door for rethinking... that Lyng is a reliable controlling decision for the substantial burden analysis." 371 Yet another scholar has argued that religion-protective statutes could be used against restrictive abortion laws because legal access to abortion could be part of one's religious exercise. ${ }^{372}$ A religious exemption from an abortion prohibition was

as LGBTQ rights, immigration, health care, and criminal justice reform).

369. See, e.g., Whose FAITH MATTERS?, supra note 30, at 5-8 (providing an overview of the recent rise of religious-based litigation).

370. See Inks, supra note 322, at 111; see also Thomas Scott-Railton, Note, A Legal Sanctuary: How the Religious Freedom Restoration Act Could Protect Sanctuary Churches, 128 YALE L.J. 408, 433 (2018) (asking "whether RFRA would provide protection to sanctuary congregations from prosecution under federal laws criminalizing various forms of assistance to undocumented individuals" and "whether RFRA would place limits on ICE's ability to conduct raids or surveillance of immigrant congregations or sanctuary churches"); Elizabeth Brown \& Inara Scott, Sanctuary Corporations: Should Liberal Corporations Get Religion?, 20 U. PA. J. CONST. L. 1102, 1130-38 (2018) (exploring the impact of Hobby Lobby and RFRA on the free exercise rights of corporations to offer sanctuary to undocumented persons); John J. Infranca, (Communal) Life, (Religious) Liberty, and Property, 2017 MicH. ST. L. REV. 481, 538-40 (2017) (adding Hosanna-Tabor Evangelical Lutheran Church \& Sch. v. EEOC, 565 U.S. 171 (2012), as yet another decision making RFRA interpretation more favorable in the sanctuary context).

371. Michael D. McNally, From Substantial Burden on Religion to Diminished Spiritual Fulfillment: The San Francisco Peaks Case and the Misunderstanding of Native American Religion, 30 J.L. \& RELIGION 36, 45 (2015) (describing how a focus on "spirituality" instead of "religion" diminishes native claims); see also Brown \& Scott, supra note 370, at 1138-40 (noting the Supreme Court's increased free exercise protections since Hobby Lobby and RFRA's potential to aid native claims); Brief of Religious Liberty Law Scholars, supra note 350, at 9-10 (arguing that an overly narrow definition of substantial burden may remove from RFRA and RLUIPA precisely the types of government action that Congress contemplated, such as restrictions on native claims).

372. Kara Loewentheil, The Satanic Temple, Scott Walker, and Contraception: A Partial Account of Hobby Lobby's Implications for State Law, 9 HARV. L. \& POL'Y REV. 89, 123 (2015) ("[O]ne could also imagine a religious belief that life is so sacred that one should only bring it into the world when one is prepared and capable and willing to support it, and that access to 
precisely the reason the Catholic bishops opposed the passage of RFRA $;{ }^{373}$ no one else at the time seriously considered the likelihood of such a claim. ${ }^{374}$ But it remains to be seen whether the broad religious liberty principles set out in the Attorney General's Guidance Document will protect progressive causes, given the vulnerabilities of affirmative claims.

Since the Trump election, the record on progressive claims under RFRA and RLUIPA (and state counterparts) has been mixed. Most of the cases involve affirmative claims, with their added complexity on the substantial burden analysis. On private property, religious claims succeed and fail. Even where they fail, progressives sometimes prevail for other reasons. ${ }^{375}$ On public property, Native American claims continue to fail because of the absence of coercion. ${ }^{376}$ And religious claims on both kinds of property continue to encounter the argument of "available legal alternatives," which some courts accept and others reject. ${ }^{377}$

\section{A. Refusal Claims: The Hobby Lobby Formulation of the Substantial Burden}

Two recent cases involve religious protest - refusal claims - against federal eminent domain action on private property. In Adorers of the Blood of Christ v. Federal Energy Regulatory Commission, a religious order of Catholic nuns sued to prevent a taking of an easement through their land for purposes of installing part of a gas pipeline known as the Atlantic Sunrise Pipeline. ${ }^{378}$ The Federal Energy Regulatory

\footnotetext{
contraception and abortion is essential to the exercise of that belief. . . If the owners of Hobby Lobby have a judicially-recognized religious belief that they must provide insurance coverage for their employees (and therefore cannot simply provide no insurance and pay the tax instead to avoid the contraceptive coverage requirement), then it seems plausible that a business owner might just as well have a religious belief that he or she must provide insurance coverage that includes coverage for abortion to their employees." (footnote omitted)).

373. House Hearings, supra note 72, at 33-35, 40-43 (statement of Mark E. Chopko, Gen. Counsel, United States Catholic Conference); id. at 270-307 (statement of James Bopp, Jr., Gen. Counsel, National Right to Life Committee, Inc.); Senate Hearing, supra note 72, at 99-115 (statement of Mark E. Chopko, Gen. Counsel, United States Catholic Conference); id. at 203-37 (statement of James Bopp, Jr., Gen. Counsel, National Right to Life Committee, Inc.).

374. See Douglas Laycock \& Oliver S. Thomas, Interpreting the Religious Freedom Restoration Act, 73 TEX. L. REV. 209, 236 n.166 (1994).

375. See infra Sections IV.A, IV.B.1, and IV.B.2.

376. See infra Section IV.C.1.

377. See infra Sections IV.B.1, IV.B.2, and IV.C.2.

378. 283 F. Supp. 3d 342, 343 (E.D. Pa. 2017), aff'd, 897 F.3d 187 (3d Cir. 2018), cert. denied, 139 S. Ct. 1169 (2019) (mem.).
} 
Commission (FERC) authorized a private company, Transco, to take and use private property all along the planned pipeline corridor, including the order's property. ${ }^{379}$ The nuns sought a preliminary injunction against pipeline construction, arguing that FERC's authorization of the taking, and the taking itself, violated RFRA. ${ }^{380}$

The Adorers sought to establish a substantial burden on their religious exercise. ${ }^{381}$ They argued that their "religious practice includes protecting and preserving creation, which they believe is a revelation of GOD, the sacredness of which must be honored and protected for future generations." ${ }^{382}$ The Adorers, who followed Pope Francis's encyclical letter, Laudato $\mathrm{Si}$, ${ }^{383}$ alleged the pipeline construction "would interfere with their ability to use their land in a manner consistent with their religious beliefs." 384 They argued that drilling and extracting natural gas could cause methane to leak, which "would contribute to global warming in a manner contrary to their religious beliefs," and harm the earth and all of humanity. ${ }^{385}$

The district court did not reach the merits of the RFRA claim, instead dismissing it for lack of subject matter jurisdiction on the grounds that the Natural Gas Act provides a specific and exclusive process for reviewing FERC decisions, which involves a rehearing of FERC orders in appellate courts. ${ }^{386}$ The Adorers missed their opportunity to raise the RFRA issue earlier in the rehearing process. ${ }^{387}$ The Third Circuit affirmed, ${ }^{388}$ and the Supreme Court denied certiorari. ${ }^{389}$

At the heart of the national debate over immigration and refugees is another federal eminent domain action. A Texas church refused to allow agents onto its property to survey and take land for part of the Trump administration's border wall. ${ }^{390}$ The government sought a temporary

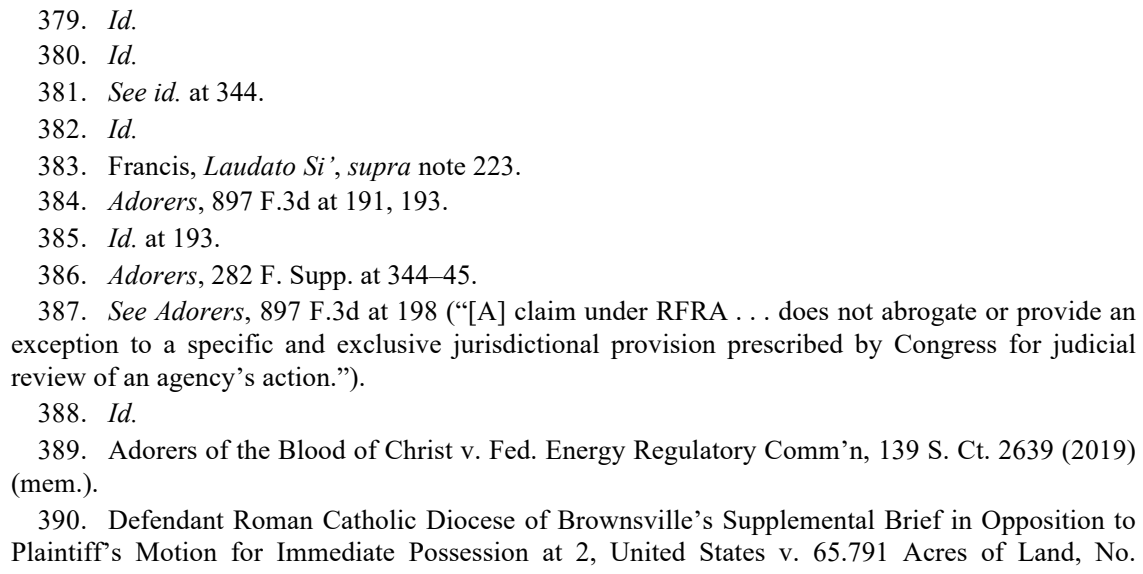


easement over two parcels, totaling about sixty-five acres, owned by the Diocese of Brownsville to survey the land and prepare it for the wall's construction. $^{391}$ One of the parcels, next to a Catholic high school, is undeveloped. ${ }^{392}$ The other is the site of La Lomita Chapel, an active place of worship for the Catholic community for over one hundred years. ${ }^{393}$ The Diocese was concerned that if the wall were built in its designated location, it would turn a tranquil environment into that of an enforcement zone. ${ }^{394}$ Further, given the likelihood of interrogation and detention for anyone suspected of not being a citizen, worshipers - even those legally in the U.S.- - would stay away. ${ }^{395}$ The Diocese, concerned that this would significantly change worship life at the chapel, refused to consent to the easement. ${ }^{396}$ The federal government sued, moving for immediate possession. ${ }^{397}$

In the Diocese's brief opposing the motion, Bishop Daniel Flores stated the rationale for the refusal. First, as to the foreseeable interference with worship, the Diocese relied on RFRA and its broad interpretation in Hobby Lobby to argue that "the proposed border wall ... would substantially burden the exercise of religious beliefs at $\mathrm{La}$ Lomita Chapel." 398 He wrote, "[I]f I were to consent to any actions that would culminate in the construction of the wall, I would be facilitating an activity that I view to be contrary to my religious and moral obligations as the head of the Diocese." 399 Second, the diocese argued that the border wall itself is contrary to Catholic teaching, so that "it cannot, as a matter of Catholic faith in practice, participate in the building of a border wall that is contrary to the Diocese's sincerely held religious beliefs." 400 "[T] he Diocese cannot consent to the erection of a physical symbol of division and dehumanization on its [p]roperty,

\footnotetext{
7:18CV00329 (S.D. Tex. Dec. 31, 2018) [hereinafter Brownsville Diocese's Brief].

391. Id.

392. Id.

393. Id.

394. Id. at 10.

395. Id. at $10-11$.

396. Id. at 11.

397. Id. at 2.

398. Declaration of Bishop Daniel E. Flores at 2, 65.791 Acres of Land, No. 7:18CV00329. The annual Palm Sunday procession of Our Lady of Guadalupe would involve 1,000 people passing through that gate in an enforcement zone. Brownsville Diocese's Brief, supra note 390, at 4, 12. Many who attend are of Latino descent and may decide not to come because of the suspicion and risk of detention. $I d$. at $11-12$.

399. Declaration of Bishop Daniel E. Flores, supra note 398, at 2.

400. Brownsville Diocese's Brief, supra note 390, at 6.
} 
especially where there are alternative means of patrolling the border."401

A federal district court found that allowing a few surveyors on the church's property did not constitute a substantial burden under RFRA. ${ }^{402}$ The litigation ended in February of 2019, when Democrats in Congress were able to obtain an exemption for the Chapel property and other sensitive properties as part of negotiations on the spending bill to fund the border wall. ${ }^{403}$

Had the courts in the Adorers' and Brownsville Diocese's lawsuits reached the merits, RFRA might have protected them, especially given the added protection of private property ownership. ${ }^{404}$ Even had these claimants not succeeded, they should have been able to establish a substantial burden, given the similarities to Hobby Lobby. Indeed, the Brownsville Diocese's argument regarding substantial burden is framed precisely as that in Hobby Lobby: the placement of the border wall on church property would "demand[] that [the Diocese] engage in conduct that seriously violates their religious beliefs." $" 405$ To consent to the border wall on church property, like providing contraception coverage, would be to facilitate activity directly contrary to its beliefs. ${ }^{406}$ Not to consent, and to have the wall placed coercively on the property, would force the church into maintaining a structure on its own property that is contrary to its beliefs. Additionally, the church would be involved in an ongoing

401. Id. at 8 .

402. Dudley Althaus \& Kathy Zezima, As Border Wall Construction Moves Ahead in Texas, Judge Rules Feds Can Survey Church's Land, WASH. Post (Feb. 6, 2019, 1:39 PM), https://www.washingtonpost.com/national/as-border-wall-construction-moves-ahead-in-texas-judge -rules-feds-can-survey-churchs-land/2019/02/06/5de32316-2a39-11e9-984d-9b8fba003e81_story.ht $\mathrm{ml}$ [https://perma.cc/3BX3-3UA7].

403. Consolidated Appropriations Act, 2019, Pub. L. No. 116-6, § 231, 133 Stat. 13, 28 (2019). The exempt properties include The Santa Ana Wildlife Refuge, the Bentsen-Rio Grande Valley State Park, the La Lomita Historical Park, the National Butterfly Center, and within or east of the Vista del Mar Ranch tract of the Lower Rio Grande Valley National Wildlife Refuge, all of which had been involved in litigation. $I d$.

404. See Infranca, supra note 370, at 487-89 (discussing shared aspects of property rights and religious liberties). For eminent domain against churches, see, for example, Yonkers Racing Corp. v. City of Yonkers, 858 F.2d 855, 858 (2d Cir. 1988) (finding that a seminary's free exercise challenge to the city's taking was not valid); Village of Bensenville v. Fed. Aviation Admin., 457 F.3d 52, 57 (D.C. Cir. 2006) (refusing to use strict scrutiny to determine whether an airport expansion burdened religious exercise). Furthermore, even conceding compelling interests in both cases, the ability to reroute a pipeline or a border wall leaves less restrictive alternatives. Note, too, that private ownership should have triggered strict scrutiny even under Smith, as a claim involving a "hybrid" of constitutional protections. See Emp't Div. v. Smith, 494 U.S. 872, 881-82 (1990).

405. Burwell v. Hobby Lobby Stores, Inc., 573 U.S. 682, 720 (2014). Specifically, the Brownsville Diocese argued that it "cannot, as a matter of Catholic faith in practice, participate in the building of a border wall that is contrary to the Diocese's sincerely held religious beliefs." Brownsville Diocese's Brief, supra note 390, at 6.

406. Brownsville Diocese's Brief, supra note 390, at 6. 
relationship with the government, requiring constant surveillance of church activity, since the wall plus a gate (as was proposed) would be within an enforcement zone. ${ }^{407}$ This would clearly deter worshipers from coming to the chapel. ${ }^{408}$ It seems that RFRA, as interpreted by Hobby Lobby - with great deference to the claimant's formulation of its burden ${ }^{409}$ - could have protected the Diocese from the taking of church property for a use that directly and symbolically violates its beliefs. ${ }^{410}$ Some liberals who were critical of Hobby Lobby may, on second thought, find the decision contains the seeds of a new growth of progressive free exercise claims.

\section{B. Affirmative Claims on Private Property}

As I have maintained, affirmative claims often do not fare as well as refusal claims. Skeptical courts are more suspicious of claims that are indeterminate, discretionary, and fluid. These affirmative claims vary widely and can involve countless interactions with law. It may be difficult to establish a substantial burden because the claimant might have alternatives, or the claim itself might be perceived as more political than religious. But one thing that does help to root these claims is when the affirmative acts are undertaken on privately-owned property. The following cases involve sanctuary and humanitarian aid to undocumented persons, charitable services to the poor, and green building uses, all involving religious claims for activity located on church-owned property.

\section{Sanctuary and Humanitarian Aid to the Undocumented}

Churches use their property for more than worship, sometimes providing sanctuary to undocumented immigrants. The Trump administration's immigration enforcement, which includes swift

407. See id. at 5 .

408. Id. at 12. Coercion is present. In Standing Rock Sioux Tribe v. U.S. Army Corps of Engineers, the presence of the pipeline interfered with ceremonial life. 239 F. Supp. 3d 77, 89-91 (D.D.C. 2017). Similarly the presence of the wall here would interfere with ceremonial life. Brownsville Diocese's Brief, supra note 390, at 12. The distinction lies in how the property is defined. The pipeline rests in a federally owned lakebed. Standing Rock, 239 F. Supp. 3d at 98-99. The border wall would sit on a federally owned easement. Brownsville Diocese's Brief, supra note 390, at 2. However, in contrast to Standing Rock's lack of coercion, the act of eminent domain to create this easement is itself a coercive act.

409. Hobby Lobby, 573 U.S. at $727-28$

410. Even conceding a compelling governmental interest, a less restrictive alternative- the narrow religious exemption in the Consolidated Appropriations Act, 2019-clearly exists. See Consolidated Appropriations Act, 2019, Pub. L. No. 116-6, § 231, 133 Stat. 13, 28 (2019). 
deportation and family separation, ${ }^{411}$ has re-energized the New Sanctuary Movement, with over a thousand houses of worship participating. ${ }^{412}$ The detention of children and relentless pursuit of undocumented immigrants throughout the nation, even those fully immersed in communities, have moved these churches to act on the biblical imperatives of welcoming the stranger and upholding human dignity. ${ }^{413}$ ICE's "large-scale practice of conducting immigration raids at Christian churches" involves the arrest of undocumented persons as they leave church. ${ }^{414}$ This has prompted further religious mobilization. ${ }^{415}$

It is unclear whether government interference in sanctuary efforts would constitute a substantial burden under RFRA. ${ }^{416}$ In contrast to the Sanctuary Movement of the 1980s, houses of worship now are more likely to openly declare themselves sanctuaries for undocumented immigrants, while at the same time not ensuring protection from immigration authorities. ${ }^{417}$ Clergy believe that RFRA and the Fourth Amendment protect this exercise of religion on their private property, ${ }^{418}$ so they are prepared to allow ICE agents to enter church property as long as they have arrest warrants. ${ }^{419}$ When a church provides sanctuary openly, without blocking warrant-bearing ICE agents, it seems that it violates no law. ${ }^{420}$ But since 2017, the Trump administration has

411. Julie Hirschfeld Davis \& Michael D. Shear, How Trump Came to Enforce a Practice of Separating Migrant Families, N.Y. TIMES (June 16, 2018), https://www.nytimes.com/2018/06/16/us/ politics/family-separation-trump.html [https://perma.cc/8ZVW-2ZJZ].

412. Jason A. Cade, Sanctuaries as Equitable Delegation in an Era of Mass Immigration Enforcement, 113 Nw. U. L. REv. 433, 475 (2018). Churches that do not offer sanctuary have also launched justice initiatives. See, e.g., Christopher White, U.S. Bishops Head to Border to Protest Trump Immigration Policies, CRUX (June 29, 2018), https://cruxnow.com/church-in-theusa/2018/06/29/u-s-bishops-head-to-border-to-protest-trump-immigration-policy/ [https:/perma.cc/ D8AE-ESC9].

413. Rose Cuison Villazor \& Pratheepan Gulasekaram, Sanctuary Networks, 103 MINN. L. ReV. 1209, 1232 (2019) ("[T] dominate much of the narrative deployed today among church members providing safe havens to undocumented immigrants.").

414. Gabriella M. D'Agostini, Treading on Sacred Land: First Amendment Implications of ICE's Targeting of Churches, 118 MICH. L. REV. 315, 319-20 (2019).

415. See Inks, supra note 322, at 112-14.

416. See id. at 143, 154 (arguing that since RFRA amends all federal law, RFRA should be implemented at a macro level, not case-by-case, to influence the interpretation of the Immigration and Naturalization Act's harboring provision to protect the many potential religious violators); see also Brown \& Scott, supra note 370, at 1140-44 (arguing that extending RFRA sanctuary protection to religiously motivated businesses would be a dangerous development for society).

417. See Cuison Villazor \& Gulasekaram, supra note 413, at 1234.

418. Id. at 1233-34.

419. Id. at 1234 .

420. See Scott-Railton, supra note 370, at 446 (describing this as the "easiest case" in which to apply the least-restrictive-means analysis because "ICE's less restrictive means would simply be to 
pledged a more aggressive enforcement of the harboring statute. ${ }^{421}$ If in a given case the harboring provisions were triggered, churches and their clergy may have difficulty establishing a substantial burden. In the 1980 s, courts rejected free exercise defenses to the enforcement of harboring provisions in part because the Christian faith did not require participation in the sanctuary movement. ${ }^{422}$ Without an absolute mandate, the existence of legal alternatives became crucial to the analysis. ${ }^{423}$ Now, even though religiously motivated acts fall explicitly within RFRA's ambit, legal alternatives may nevertheless reduce the magnitude of the burden. One scholar, recognizing this vulnerability, has shown how a church can legitimately argue that it has no option but to provide sanctuary:

If a congregation saw sanctuary as no more than one of several perfectly equivalent means of performing their duty of care to others, the burden might not be substantial. Substantial burdens would still likely exist where congregations thought that there was something unique about sanctuary, such that a congregation did not feel there was another way to fulfill their obligations. This might be particularly stark along the border, where humanitarian activists face the question of turning away migrants in physical distress or in need of food and water. ${ }^{424}$

This suggests that a church must build a strong case to establish that it was under religious compulsion to act in a particular way-not compelled by specific church rule but by the intensity of the commitment to broad church teaching and the exigencies of time, circumstances, and place. This is just another way of saying that the church must demonstrate that it makes a theological determination regarding the means by which it will inculturate the broad teachings of its faith, like welcoming the stranger or loving one's neighbor.

Other churches use their property not for sanctuary but as a staging

follow the procedures it would for any home: get a warrant").

421. See Memorandum from Jeff Sessions, Att'y Gen., to All Fed. Prosecutors (Apr. 11, 2017), https://www.justice.gov/opa/press-release/file/956841/download [https://perma.cc/S5LM-ZMAB].

422. See, e.g., United States v. Merkt, 794 F.2d 950, 956 (5th Cir. 1986) ("Representatives of Catholic and Methodist clergy... [never] suggested that devout Christian belief mandates participation in the "sanctuary movement."'); $c f$. United States v. Aguilar, 883 F.2d 662, 694 (9th Cir. 1989).

423. See, e.g., Merkt, 794 F.2d at 956 ("Obviously, appellants could have assisted beleaguered El Salvadorans in many ways which did not affront the border control laws.... They chose confrontational, illegal means to practice their religious views - the 'burden' was voluntarily assumed and not imposed on them by the government.").

424. Scott-Railton, supra note 370 , at 472 (emphasis added). 
area for charitable efforts for undocumented immigrants. Crossing the southwest border is profoundly dangerous. Many have died in the process, and those who survive still often suffer exhaustion, dehydration, heatstroke, and other ills from the arduous trek. ${ }^{425}$ A ministry of the Unitarian Universalist Church of Tucson, known as No More Deaths, has organized to offer humanitarian aid in the desert and to find the bodies of those who have died. ${ }^{426}$ The ministry operates out of a building known as the Barn in Ajo, Arizona. ${ }^{427}$ Border Patrol agents began surveilling the Barn after No More Deaths released a report criticizing the agency. ${ }^{428}$ In January 2018, Border Patrol agents arrested Dr. Scott Warren, an active volunteer with No More Deaths, when he assisted two undocumented persons at the Barn. ${ }^{429}$ He was charged with one count of criminal conspiracy to transport and harbor illegal aliens and two counts of harboring, ${ }^{430}$ the basis of which "include[d] providing food, water, shelter, and clean clothes to, as well as talking to, two undocumented migrants." 431 Dr. Warren, for whom "humanitarian aid is a "sacred act," 432 testified that his faith "requires him to care for people that he believes are in distress." $" 433$

Dr. Warren moved to dismiss the charges under RFRA. ${ }^{434}$ In a December 2018 order, a magistrate judge denied the motion. ${ }^{435}$ The magistrate judge based his decision on an evidentiary hearing he presided over. $^{436}$ There, the magistrate judge concluded that Dr. Warren did not

425. Paul Ingram, Prosecutors Argue No More Deaths Volunteer Conspired to Protect 2 Men in Country Illegally, TUCSON SENTINEL (May 29, 2019, 4:46 PM), http://www.tucsonsentinel.com/ local/report/052919_warren_nmd_trial/prosecutors-argue-no-more-deaths-volunteer-conspired-prote ct-2-men-country-illegally/ [https://perma.cc/ERZ7-WXLU] (noting more than 3,000 deaths in the desert between 2000 and 2018).

426. Id.

427. Id.

428. Id.

429. Id

430. Id.

431. Brief of and by Professors of Religious Liberty as Amicus Curiae in Support of Defendant's Motion to Dismiss at 13, United States v. Warren, No. CR-18-00223-001-TUC-RCC, 2018 WL 4403753 (D. Ariz. Sept. 17, 2018) [hereinafter Warren Professors' Amicus Brief].

432. Id. at $6 \mathrm{n} .2$.

433. Id. at 13 .

434. United States v. Warren, No. MJ-17-0341-TUC-BPV, 2018 WL 6809430, at *2 (D. Ariz. Dec. 27, 2018).

435. Id. at $* 5$.

436. Id. at *2 (quoting United States v. Warren, No. CR-18-223-TUC-RCC(BPV), 2018 WL 5257807 , at $* 2$ (D. Ariz. May 31, 2018) (report and recommendation of magistrate judge)). 
establish a substantial burden because:

At no time during the Defendant's testimony did he claim that his religious beliefs necessitated he aid undocumented migrants, only that he was compelled to aid persons in distress.... Nor has he asserted or testified that his beliefs require he assist people illegally in this country to evade apprehension or reach their ultimate destination. ${ }^{437}$

The magistrate judge focused on whether Dr. Warren's beliefs compelled him to actively and directly violate this law. ${ }^{438}$ Dr. Warren failed in that regard, because his beliefs only compelled him to provide humanitarian aid. ${ }^{439}$ Presumably, under the court's reasoning, Dr. Warren had legal alternatives: since Dr. Warren was not compelled to help these particular men in this particular place and in this particular way, he could have worked at a soup kitchen or helped in any number of other ways to live out his religious beliefs.

The magistrate judge misapprehended the nature of the affirmative claim. The magistrate judge ignored the context and found that the criminal statutes did not specifically compel Dr. Warren "to do anything in violation of his religious beliefs." 440 Notice how the magistrate judge imposes a refusal claim model on an affirmative claim. The harboring law did not mandate any particular action; rather, it restrained Dr. Warren's religious action. ${ }^{44}$ Affirmative acts restrained by law are by definition broader than the acts involved in refusal claims because refusal claims are determined by what the law requires, while affirmative claims are determined by what the religion teaches.

Though affirmative claims and refusal claims arise from different faith-law interactions, the conflict between faith and law for affirmative claims is no less direct than for refusal claims. The law professors' amicus brief criticized the magistrate judge's determination as a complete misreading of Supreme Court precedent when it noted that " $[\mathrm{t}]$ he question is not whether defendant's religious beliefs commit him to violate the law, but whether his beliefs commit him to undertake acts that are otherwise treated as illegal" under the law. ${ }^{442}$ Because " $[t]$ he bases for Dr. Warren's charges are entirely RFRA-protected activities," his prosecution gave him the choice of either "violating his religious

\footnotetext{
437. Warren, 2018 WL 5257807, at *2.

438. See id.

439. Id.

440. Id.

441. See 8 U.S.C. $§ 1324(a)(1)(A)(i i i)(2018)$.

442. Warren Professors' Amicus Brief, supra note 431, at 12.
} 
beliefs or risking criminal prosecution-undoubtedly a substantial burden." $" 43$

While his RFRA defense was unsuccessful, Dr. Warren was ultimately acquitted in a retrial after a first trial ended in a deadlocked jury, ${ }^{444}$ which suggests the jury was troubled by the way in which the prosecution criminalized humanitarian assistance. It further suggests moral ambivalence toward government surveillance of private property that is dedicated to such works.

\section{Charitable Works and Environmental Stewardship at the Local Level}

As we saw above in cases like Western Presbyterian v. Board of Zoning Adjustment of District of Columbia ${ }^{445}$ and Harbor Missionary Church v. City of San Buenaventura ${ }^{446}$ churches continue to need regulatory latitude to serve the poor on their properties. With the passage of RLUIPA in $2000,{ }^{447}$ federal law began to protect religious land uses at the local level. The statute has become a powerful deterrent to municipal discrimination and mishandling of religiously affiliated applicants. Yet the courts continue to apply the substantial burden prong in varied ways.

One thread of cases has been quite solicitous of the provision of charitable works. A recent case illustrating this continued solicitude, Ward v. Metropolitan Government of Nashville and Davidson County, ${ }^{448}$ involved the Nashville Methodist Church. In alliance with an interfaith housing organization, the church received an accommodation from strict application of a zoning code in order to construct transitional housing (twenty-two micro-homes) for homeless persons on church property. ${ }^{449}$ Aggrieved neighbors sued to stop the development, but the Tennessee Court of Appeals affirmed the trial court, which held that the zoning board's decision to accommodate the church was not arbitrary or capricious. ${ }^{450}$ The court found that both the church and the interfaith organization were motivated by the religious desire to provide housing to

\footnotetext{
443. Id. at 14 .

444. See Allyn, supra note 44.

445. 862 F. Supp. 538 (D.D.C. 1994); see supra notes 281-85 and accompanying text.

446. 642 F. App'x 726 (9th Cir. 2016); see supra notes $293-98$ and accompanying text.

447. 42 U.S.C. $\S \S 2000 \mathrm{cc}-2000 \mathrm{cc}-5$ (2012).

448. No. M2018-00633-COA-R3-CV, 2019 WL 1753053 (Tenn. Ct. App. Apr. 17, 2019).

449. $I d$. at $* 1$.

450. Id. at $* 8-9$.
} 
the poor. ${ }^{451}$ Since federal policies had shifted away from transitional housing, Nashville's needs were urgent. ${ }^{452}$ The Tennessee RFRA defines substantial burden as state action that "inhibit[s] or curtail[s] religiously motivated practice." 453 This definition clearly recognizes and accepts the indeterminacy of an affirmative claim. Applying the factors set out in applicable RLUIPA precedent, it was clear that without the accommodation this religiously motivated housing could not be built without significant cost and delay, that no feasible alternative location existed, and that the church had not brought this burden on itself. ${ }^{454}$ By looking at the full context, the court had little difficulty finding a substantial burden under the state RFRA. ${ }^{455}$

Although RLUIPA and state statutes have offered more robust protections for religious land use, disputes over church use of solar panels have just started to reach courts. As noted above, with the growing acceptance of alternative energy sources, many churches are trying to reduce their carbon footprints as better stewards of the environment. ${ }^{456}$ A new movement to install solar panels on houses of worship is gaining traction, with about a thousand congregations having done so and organizations like Interfaith Power and Light, ${ }^{457}$ which has chapters in thirty-eight states, encouraging others to do so. ${ }^{458} \mathrm{~A}$ Unitarian Universalist church situated in a historic district sued the town of Bedford, Massachusetts when its commission denied permission to install solar panels on its meetinghouse. ${ }^{459}$ The Church argued that this denial violated its right to the free exercise of religion under the state and federal constitutions, inter alia. ${ }^{460}$ The Church contended that the use of solar panels was religious conduct because one of the seven principles of Unitarian Universalism is "respect for the interdependent web of all existence of which we are a part." ${ }^{\text {"61 }}$ The Church believed that these principles require members "to engage in affirmative acts of

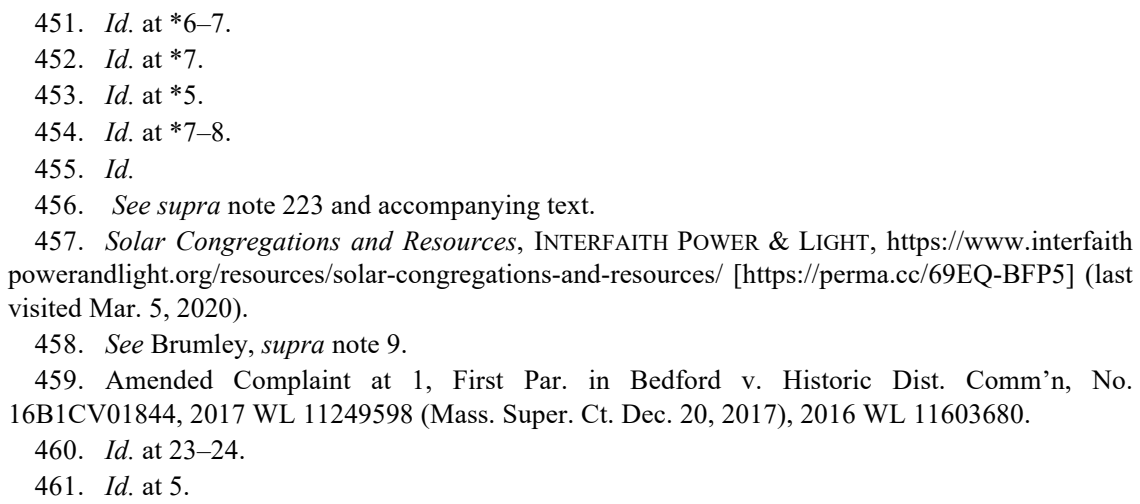


environmental conservation," which are "essential to their religious practice." $" 462$ In keeping with this principle, the Church applied to the Unitarian Universalist Association to become a Green Sanctuary church, which requires the use of solar panels. ${ }^{463}$ The Church explained that "Unitarian Universalists across the nation believe that their religion necessarily involves taking action on a personal, congregational and community level to confront and mitigate mankind's role in causing and exacerbating global warming." 464 The Church further claimed that this religious conduct did not "disturb[] the public peace" or "obstruct[] the religious worship of others," 465 tracking the text of the Massachusetts religious freedom provision. ${ }^{466}$

The Church lost its religious freedom claim, but prevailed on a procedural claim. ${ }^{467}$ The court found the historic commission's denial facially deficient because the commission failed to explain how the solar panels materially interfered with the building's "historic and iconic visage." ${ }^{468}$ As to the religious freedom claim, the court found no substantial burden to the Church's religious exercise because the refusal to allow solar panels "neither prevented First Parish's congregants from living in accordance with the Seventh Principle of Unitarian Universalism nor coerced them to act contrary to that belief."469 Then, like some other courts addressing affirmative claims, the court raised the idea that the church had options to address climate change: "[T]hey can take other available avenues to achieve a similar result. For instance, the congregants could invest in other renewable forms of energy, local to the Meetinghouse or otherwise, or engage in and promote other community conservation or recycling efforts." $" 70$

The question now is whether similar solar energy cases or other environmental-based land use claims brought under RLUIPA, or state

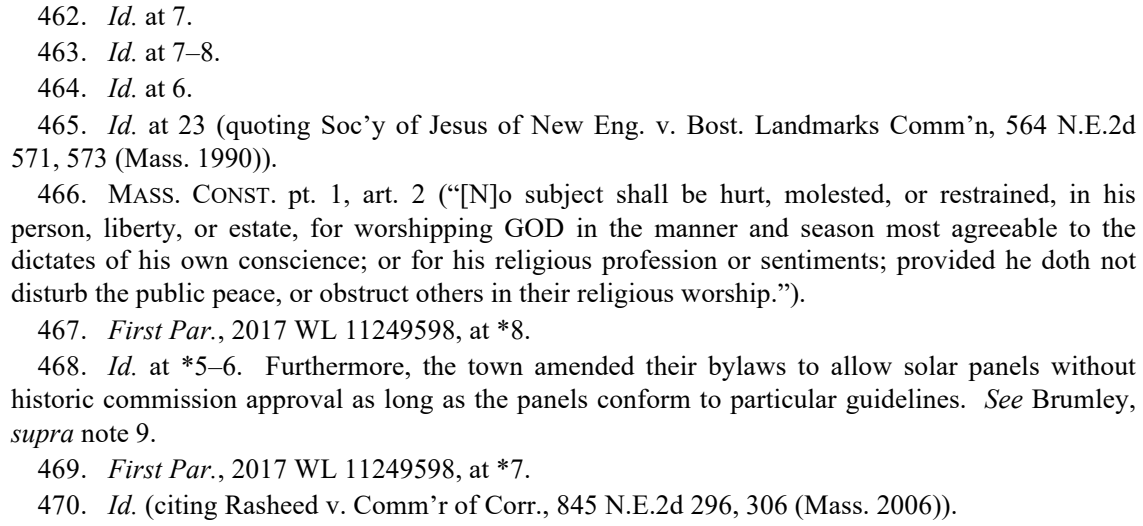

466. MASS. CONST. pt. 1, art. 2 ("[N]o subject shall be hurt, molested, or restrained, in his person, liberty, or estate, for worshipping GOD in the manner and season most agreeable to the dictates of his own conscience; or for his religious profession or sentiments; provided he doth not disturb the public peace, or obstruct others in their religious worship."). 
constitutions or statutes, will succeed. Of course, the answer depends on whether courts will focus on the existence of alternatives and how "substantial burden," which varies from circuit to circuit, case by case, is defined.

\section{Affirmative Claims on Public Property}

Affirmative claims on private property will not always prevail, but private property ownership undoubtedly adds a protective dimension to religious exercise. When church property is used for sanctuary for undocumented immigrants, to house the homeless, to provide basic human needs, or to protect the environment, the affirmative claim is "rooted." Constitutional protections of private property and specific statutory solicitude in RLUIPA demonstrate the importance of place. ICE does not raid houses of worship that offer sanctuary, churches routinely offer charitable services without municipal interference, and the movement toward solar energy has not hit any major resistance. These are not only claims to act in accord with one's faith but also in accord with one's faith on one's own property. However, when religious groups exercise their faith affirmatively on public property, the loss of this rootedness may have doctrinal consequences.

\section{No Coercion}

As noted above, the tribes in Lyng did not establish a substantial burden because they could not meet the threshold requirement of coercion. $^{471}$ Lyng's rule continues to frustrate Native American landbased claims. The Standing Rock protest in North Dakota, which began in the spring of 2016 and drew thousands in protest of the Dakota Access Pipeline, was one of the biggest progressive religious movements in recent history. The pipeline, intended to carry nearly a half million barrels of crude oil through four states each day, was slated to go through sacred lands and burial grounds. ${ }^{472}$ For these reasons, it was viewed as a threat to both Native American spiritual life and culture and to the entire region's clean water. ${ }^{473}$ By the fall of 2016, more than two hundred tribes, many environmental groups, and over five hundred clergy and

471. Lyng v. Nw. Indian Cemetery Protective Ass'n, 485 U.S. 439, 449 (1988).

472. Jessica Ravitz, The Sacred Land at the Center of the Dakota Pipeline Dispute, CNN (Nov. 1, 2016, 2:01 PM), https://www.cnn.com/2016/11/01/us/standing-rock-sioux-sacred-land-dakotapipeline/index.html [https://perma.cc/BX8P-V2JD].

473. Id. 
religious people (representing many Christian denominations and other faiths) had joined. ${ }^{474}$ The protest was also called a "prayer camp," because for many protesters the environmental and religious concerns are inextricably connected. ${ }^{475}$

In multiple lawsuits, tribes sued the U.S. Army Corps of Engineers on the grounds that granting permits to the pipeline, which bordered tribal reservations, violated a slew of federal statutes. ${ }^{476}$ They argued that preparing the land for construction would jeopardize historically and culturally significant sites and that the Corps had not adequately considered environmental impacts. ${ }^{477}$ Significant for this Article, they also invoked RFRA to claim that the pipeline endangered the religious exercise of tribal members. ${ }^{478}$

By early 2017, only twenty miles of pipeline remained unfinished. The Army Corps of Engineers still had to grant an easement for pipeline construction through the lakebed of Lake Oahe, which is a federally regulated waterway forming part of the Missouri River. ${ }^{479}$ Fresh from inauguration, Trump reversed a recent Obama administration decision to consider alternatives, and ordered an expedited approval process. ${ }^{480}$ The easement was quickly granted in February, and one day later the Cheyenne River Tribe sought a preliminary injunction to block it on the grounds that the construction of the pipeline would interfere with its religious exercise. ${ }^{481}$ In Standing Rock Sioux Tribe v. U.S. Army Corps of Engineers, the tribe claimed:

The Lakota people believe that the mere existence of a crude oil pipeline under the waters of Lake Oahe will desecrate those waters and

\footnotetext{
474. Michael Brune, A Light Shines in the Dakotas, SIERRA Club (Sept. 14, 2016), https://www. sierraclub.org/michael-brune/2016/09/standing-rock-sioux-dakota-pipeline [https://perma.cc/DGU3T7CF]; Brian Roewe, Larger Faith Community Comes to Standing Rock in Solidarity, NAT'L CATHOLIC REP. (Nov. 7, 2016), https://www.ncronline.org/blogs/eco-catholic/larger-faithcommunity-comes-standing-rock-solidarity [https://perma.cc/7GCW-8TLA].

475. Jack Jenkins, How Religious Conservatives Unwittingly Laid the Groundwork to Help Native Americans Save Their Land, THINKPROGRESS (Dec. 8, 2016, 6:31 PM), https:// thinkprogress.org/standing-rock-religious-liberty-d0a6aacef81c/ [https://perma.cc/D63B-C8NN].

476. See Standing Rock Sioux Tribe v. U.S. Army Corps of Eng'rs, 239 F. Supp. 3d 77, 80-81 (D.D.C. 2017) (noting the tribes claimed violations of the National Environmental Policy Act, the National Historic Preservation Act, the Clean Water Act, the Rivers and Harbors Act, the Mineral Leasing Act, and the Administrative Procedures Act, among others).

477. Standing Rock Sioux Tribe v. U.S. Army Corps of Eng'rs, 255 F. Supp. 3d 101, 111-12 (D.D.C. 2017).

478. See Standing Rock, 239 F. Supp. 3d at 82-83, 87-98.

479. Id. at $80-81$.

480. Id. at $80-82$.

481. Id. at 82 .
} 
render them unsuitable for use in their religious sacraments. The Lakota people believe that the pipeline correlates with the terrible Black Snake prophesied to come into the Lakota homeland and cause destruction. The Lakota believe that the very existence of the Black Snake under their sacred waters in Lake Oahe will unbalance and desecrate the water and render it impossible for the Lakota to use that water in their Inipi ceremony. ${ }^{482}$

Because their water-based religious ceremonies require ritually pure water, the tribe claimed a RFRA violation. ${ }^{483}$

The district court held that the tribe did not demonstrate a likelihood of success on the merits of the RFRA claim and denied the motion for a preliminary injunction. ${ }^{484}$ Although the court accepted that the Black Snake beliefs were sincere, the pipeline construction created no "substantial burden" on the tribe members' religious practice. ${ }^{485}$ The grant of the pipeline easement "does not impose a sanction on [t]ribe's members for exercising their religious beliefs, nor does it pressure them to choose between religious exercise and the receipt of government benefits." 486 In other words, it failed to meet Lyng's coercion requirement. ${ }^{487}$

The court acknowledged that the government action - the grant of the easement for the pipeline in the lakebed-would desecrate a sacred site and prevent the performance of religious sacraments. ${ }^{488}$ But it found this impact incidental and noncoercive. ${ }^{489}$ While the tribe may believe it cannot use the water for their ceremonies when oil flows through the pipeline, "there is no specific ban on their religious exercise, nor does performance of their sacraments trigger a sanction, loss of government benefit, or other collateral harm." 490 Thus, the D.C. Circuit explained, "[j] ust as the government's tree cutting and road building in Lyng did not give rise to an actionable Free Exercise claim, neither does its easement granting here likely violate RFRA."491

482. Intervenor-Plaintiff Cheyenne River Sioux Tribe's Motion for Preliminary Injunction (Oral Argument Requested) at 2-3, Standing Rock, 239 F. Supp. 3d 77 (No. 1:16-cv-1534-JEB), 2017 WL 1454128.

483. Standing Rock, 239 F. Supp. 3d at 88-90.

484. Id. at $91-92,100$.

485. Id. at 91-92.

486. Id. at 91 .

487. Id. at $92-93,96$.

488. Id. at 91 .

489. Id.

490. Id. at $95-96$.

491. Id. at 93 . 
This outcome turned on federal ownership of the sacred land: no burden on religion could be established when the land through which the road was built in Lyng and the land beneath the sacred waters in Standing Rock was public land. ${ }^{492}$ Where Native Americans own their own land, they can look to RLUIPA for protection. ${ }^{493}$

Despite the hopeful scholarly suggestions that RFRA can offer robust protection for Native American religious claims, ${ }^{494}$ the coercion prerequisite remains for now a formidable obstacle. The district court in Standing Rock found that recent decisions did not affect Lyng's coercion requirement, which applies to both constitutional and statutory free exercise. ${ }^{495}$ It also found that plaintiffs in both Hobby Lobby and Holt suffered coercion, as each was forced to choose between violating their beliefs and facing penalties, either financial or disciplinary. ${ }^{496}$ Native American claims on federally owned land are typically not cognizable, despite the severity of any burdens, although one district court has held otherwise. ${ }^{497}$ Broadly speaking, when your sacred space encompasses land owned by another - especially land owned by the government-it is well-nigh impossible to show that your free exercise rights were violated.

As to the numerous other claims in the Standing Rock litigation, the Native American tribes lost. ${ }^{498}$ The pipeline is built and oil production is booming. ${ }^{499}$

492. Id. The Lyng Court made clear that the Native Americans could not dictate how the government could use "what is, after all, its land." Id. at 99 (quoting Lyng v. Nw. Indian Cemetery Protective Ass'n, 485 U.S. 439, 453 (1988)).

493. See, e.g., Press Release, supra note 216 (quoting New Jersey U.S. Attorney Craig Carpenito: "RLUIPA protects the rights of all religious communities to worship on their land free from discriminatory barriers and unlawful burdens").

494. See McNally, supra note 371, at 41; Brown \& Scott, supra note 370, at 1140; Brief of Religious Liberty Law Scholars, supra note 350, at 10.

495. Standing Rock, 239 F. Supp. 3d at 97-98.

496. Id. at 96 .

497. See Comanche Nation v. United States, No. CIV-08-849-D, 2008 WL 4426621, at *17 (W.D. Okla. Sept. 23, 2008) (finding a RFRA substantial burden where a building on federal land blocked a view of a sacred site, significantly impairing tribe members" "spiritual experience").

498. Litigation is ongoing. For Standing Rock Sioux Tribe litigation updates, see The Standing Rock Sioux Tribe's Litigation on the Dakota Access Pipeline, EARTH JUSTICE, https://earthjustice.org/features/faq-standing-rock-litigation [https://perma.cc/F2MN-SMJT] (last visited Feb. 23, 2020).

499. Jeff Brady, 2 Years After Standing Rock Clash, Tensions Remain but Oil Business Booms, NPR (Nov. 29 2018, 7:20 AM), https://www.npr.org/2018/11/29/671701019/2-years-after-standingrock-protests-north-dakota-oil-business-is-booming [https://perma.cc/E6HD-TGBX]. 


\section{The Existence of Alternatives}

While skeptical courts may make it difficult, if not impossible, to establish a substantial burden when the religious actor brings an affirmative claim but had an option that involved no conflict with the law, refusal claims typically do not admit of options. Refusing to do what the law commands results in automatic penalties, so there is a tight fit between the legal and religious conflict. Indeed, note how Hobby Lobby details the lack of options in the substantial burden discussion: "If the owners comply with the HHS mandate, they believe they will be facilitating abortions, and if they do not comply, they will pay a very heavy price [in penalties]." in conduct that seriously violates their religious beliefs." 501 If they don't meet these demands, severe financial penalties follow. ${ }^{502}$ If they provide coverage in accordance with their religion, they suffer massive fines. ${ }^{503}$ The Court rejected the suggestion that the companies had the option of dropping coverage altogether, for that also entailed substantial financial penalties and could create a competitive disadvantage. ${ }^{504}$ In short, refusal claims show that the religious actor is in a box.

In contrast, affirmative claims are amenable to the existence of alternatives, which can affect the free exercise analysis. Two recent magistrate judge decisions demonstrate the vulnerabilities of affirmative claims when alternatives exist. ${ }^{505}$ In both cases, the magistrate judges were substantial-burden skeptics, ruling against protesters and humanitarian aid volunteers. ${ }^{506}$ Wisely, both determinations were overturned by federal district court judges who found a substantial burden under RFRA. ${ }^{507}$ The analysis of those magistrate decisions remains instructive as an illustration of the ease with which alternatives can thwart the finding of burden if a court is inclined toward skepticism.

In April of 2018, after two years of prayer, seven members of the

\footnotetext{
500. Burwell v. Hobby Lobby Stores, Inc., 573 U.S. 682, 691 (2014).

501. Id. at 720 .

502. $I d$.

503. Id. at 726 .

504. Id. at $720-22$.

505. See United States v. Kelly, No. 2:18-cr-22, 2019 WL 5077546 (S.D. Ga. Apr. 26, 2019), report and recommendation adopted, No. CR 2:18-022, 2019 WL 4017424 (S.D. Ga. Aug. 26, 2019) (adopting the magistrate judge's report and recommendation, but rejecting the RFRA substantial burden analysis); United States v. Hoffman, No. MJ-17-0339-TUC-BGM, 2018 WL 2464115 (D. Ariz. June 1, 2018), rev'd, No. CR1900693001TUCRM, 2020 WL 531943 (D. Ariz. Feb. 3, 2020).

506. See Kelly, 2019 WL 5077546, at*22-26; Hoffman, 2018 WL 2464115, at *2-3.

507. See Kelly, 2019 WL 4017424, at*1; Hoffman, 2020 WL 531943, at*1.
} 
Plowshares Movement, all Catholics, illegally cut through locks and entered high security areas of Naval Submarine Base Kings Bay in Georgia to spray paint antinuclear protest messages, pour blood, hammer statues of missiles, unfurl banners, and pray in an act of "nonviolent symbolic disarmament." ${ }^{, 08}$ Plowshares is a Christian pacifist groups founded in 1980 to oppose nuclear weapons. They believe that the government's Trident missile program is a war crime that threatens the existence of all of humanity. ${ }^{509}$ The government charged each of the seven members with three felonies and one misdemeanor, including trespass, destruction of government property, and conspiracy. ${ }^{510}$ In United States v. Kelly, the magistrate judge denied the defendants' motion to dismiss the charges on RFRA grounds, inter alia. ${ }^{511}$

The defendants argued that they refused to be complicit through inaction, which compelled them to "preach the gospel of nonviolence" to the military and to protest the threat to humanity. ${ }^{512}$ The defendants engaged in nonviolent symbolic disarmament to re-consecrate the very land that has been desecrated by the presence of nuclear missiles. ${ }^{513}$

A theologian and a bishop served as expert witnesses, describing how Catholic social teaching supports an understanding of the defendants' actions as prophetic and sacramental, how Catholics must answer for complicity in social injustice and so need to act, based on conscience, and how the immorality of nuclear weapons has long been a topic of Christian and specifically Catholic ethics. ${ }^{514}$ Of importance to these experts was that the lawbreaking was nonviolent resistance, ${ }^{515}$ in the tradition of Martin Luther King, Jr. It was prophetic in that one violates unjust laws in order to transform them. ${ }^{516}$ And it was sacramental because one resists at a particular physical location-here, the land desecrated by missiles - in order to reclaim and reconsecrate that space..$^{517}$

The federal magistrate judge made clear that in order to demonstrate a substantial burden under RFRA, one must show that the government

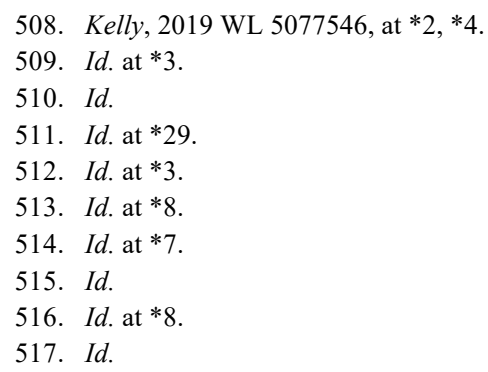


places "significant pressure" on a person to violate a sincerely held religious belief. ${ }^{518}$ He noted that the substantial burden inquiry has both a subjective and objective part, with the former deferring to the religious sensibilities of the claimant, but the latter asking the hard question: whether the law or policy "directly conflicts with the religious conduct and, if so, whether the pressure the law exerts is substantial." ${ }^{519}$ In other words, the law must "directly put [the] [d]efendants in a choice to break the law or abstain from their religiously required practice." 520

The defendants argued that indeed they were put to the choice to break the law (i.e., entering the base illegally to engage in nonviolent symbolic disarmament) or abstaining from this religious practice (i.e., being complicit in a grave injustice against humanity). ${ }^{521}$ But the magistrate judge saw it differently. He found that the defendants had failed to show a direct conflict between the religious conduct and the laws of trespass, injury to government property, or conspiracy. ${ }^{522}$ They were not put to a direct choice between following those laws or their faith because they had options. ${ }^{523}$ In the magistrate judge's view, the defendants could have asked for and received permission to enter the location (as some other religious groups had done) or they could have protested at an alternative, less secure location on the base. ${ }^{524}$ The Plowshares Seven did not demonstrate "a sincere religious belief that required them to engage in [their protest] activities without permission or on portions of the facility behind the perimeter fence line." 525 They failed to show that their beliefs required them to cut locks and fences to access the secure portion of the base. ${ }^{526}$ Thus, they could have engaged

\footnotetext{
518. Id. at *23 (citations omitted).

519. Id. at $* 23-24$ (citations omitted).

520. Id. at $* 29$.

521. Id. at $* 15$.

522. Id. at $* 25$. The magistrate judge defined a direct conflict between law and faith in very narrow terms, making it impossible for the defendants to meet the burden and completely neutralizing the religious-moral action. The court defined government action not as the maintenance of the missile program but instead the specific laws under which defendants are charged, such as trespass. Id. Further, the court defined religious exercise in terms of what one's religion requires. $I d$. Of course, the protesters could not demonstrate that their faith required them to trespass and destroy government property to gain access specifically to the high security areas. See id. The end was not to gain access but to engage in symbolic disarmament right on desecrated land. $I d$. at *3-4.

523. Id. at $* 25-26, * 29$.

524. Id.

525. Id. at $* 25$.

526. $I d$. at $* 26$. RFRA protects religiously motivated exercise. Id. at $* 20$. Under RFRA, "religious exercise" explicitly includes "any exercise of religion, whether or not compelled by, or central to, a system of religious belief." 42 U.S.C. § 2000bb-2(4) (2012) (emphasis added) (citing §
} $2000 \mathrm{cc}-5(7)(\mathrm{A}))$. 
in their symbolic disarmament at another location on the base, outside the secured perimeter. ${ }^{527}$ Given the existence of these lawful options, "there is no direct conflict between their religious exercise and the criminal statutes under which they are charged, and thus, no substantial burden exists." 528 Wisely, the federal district court rejected this analysis. ${ }^{529}$ Though it still ruled against the protesters because of the government's interest in the security of its bases, the district court found that defendants had indeed been substantially burdened in the exercise of their religion. ${ }^{530}$

Like the magistrate judge's analysis in Dr. Warren's case, the magistrate judge in United States $v$. Kelly treated an affirmative claim by the standards applicable to refusal claims. As explained above, refusal claims are generated by what the law requires while affirmative claims are determined by what the religion teaches. A refusal claim is a direct attack on the law. It is unremarkable that the Plowshares Seven had no direct objection to trespass law. An affirmative claim is structured differently, as it is based primarily upon the religious party's decision to act - on the basis of a theological determination as to how one inculturates a broader religious command in a particular time, place, and circumstance. A court treating an affirmative claim like a refusal claim will look for a narrow and specific tenet that tells the claimant to violate the law. The court will not find it. Yet even though affirmative and refusal claims arise from different faith-law interactions, the conflict between faith and law for affirmative claims is no less direct than for refusal claims.

In October 2019, the Plowshares Seven were found guilty of three felonies and one misdemeanor each, including conspiracy, trespassing

527. Untied States v. Kelly, No. CR 2:18-022, 2019 WL 5077546, at *26 (S.D. Ga. Aug. 26, 2019).

528. Id. The trespass and destruction of property were only a means to getting to the base to perform symbolic disarmament, but it could have been done without breaking those laws. See id. The magistrate judge went on to analyze the compelling governmental interest and least restrictive purpose prongs, even though no substantial burden was demonstrated. Id. He found that the government established a compelling interest in protecting its property, prohibiting unauthorized entry, and ensuring the security of the base and its personnel. Id. at *27-28. He further determined that the government demonstrated that no alternative means existed for achieving its goals without imposing a substantial burden on religious exercise. $I d$. at $* 29$. When the defendants offered "permitted protest" as the least restrictive alternative, the magistrate judge noted that just such an option might have been available, had they asked. Id.

529. The court refused to "look at whether Defendants could have exercised their religion outside the perimeter fence... or whether they could have asked for authorization." Kelly, 2019 WL 4017424 , at *4.

530. Id. at $* 4, * 7$. 
and defacing government property. ${ }^{531}$ They face up to twenty-five years in prison. ${ }^{532}$

A similar concern about alternatives colored the magistrate judge's analysis in United States v. Hoffman. ${ }^{533}$ Volunteers with No More Deaths, the desert ministry of Tucson Unitarian Church mentioned above in connection with Dr. Scott Warren's humanitarian work at the Barn, took substantial risks to venture into the desert, a national wildlife refuge, to leave water and food for undocumented border crossers. ${ }^{534}$ Federal agents destroyed the No More Deaths provisions they found. ${ }^{535}$ In early 2019, four volunteers-Natalie Hoffman and three others-were convicted of misdemeanors for entering the refuge without a permit and for leaving supplies, violations of federal law. ${ }^{536}$

The magistrate judge rejected the volunteers' RFRA defense in part because he considered their beliefs to be political, rather than religious. ${ }^{537}$ Further, he concluded that limited access to the refuge caused no substantial burden on their religious exercise. ${ }^{538}$ Perhaps the magistrate judge was thinking about the No More Deaths volunteers like the other magistrate judges had thought about Dr. Warren and about the Plowshares Seven: they had options to satisfy their religious thirst for

531. Colleen Dulle, Catholic Anti-Nuke Activists Guilty on All Counts in Georgia Court, AM. MAG. (Oct. 24, 2019), https://www.americamagazine.org/politics-society/2019/10/24/catholic-antinuke-activists-guilty-all-counts-georgia-court [https://perma.cc/Z93P-C67N].

532. Id.

533. No. MJ-17-0339-TUC-BGM, 2018 WL 2464115, at*3 (D. Ariz. June 1, 2018) (suggesting the defendants could have sought to obtain permits for access to the location or a special use permit), cert. denied, 139 S. Ct. 2615 (2019) (mem.).

534. Paul Ingram, No More Deaths Volunteers Fined \$250, Sentenced to 15 Months' Probation, TUCSON SENTINEL (Mar. 1, 2019, 2:29 PM), http://www.tucsonsentinel.com/local/ report/030119_no_more_deaths/no-more-deaths-volunteers-fined-250-sentenced-15-mos-probation/ [https://perma.cc/48UP-PXU6] [hereinafter Ingram, No More Deaths Volunteers Fined]; Paul Ingram, No More Deaths Volunteer Testifies, supra note 45.

535. Elizabeth Boylan, Professors of Law and Religion File Brief Supporting Arizona Immigration Rights Activist's Use of RFRA as a Defense to Federal Criminal Prosecution, ColuM. L. BLOG (June 21, 2018), http://blogs.law.columbia.edu/publicrightsprivateconscience/2018/06/21/ professors-of-law-and-religion-file-brief-supporting-arizona-immigration-rights-activists-use-of-rfraas-a-defense-to-federal-criminal-prosecution/ [https://perma.cc/Z2LZ-F53R].

536. Ingram, No More Deaths Volunteers Fined, supra note 534; see also Curt Prendergast, Tucson Federal Judge Convicts 4 Border-Aid Volunteers, TUCSON.COM (Jan. 18, 2019), $\mathrm{https}$ :/tucson.com/news/local/tucson-federal-judge-convicts-border-aid-volunteers/article_237e51ce -1b6f-11e9-9c3c-ab5ab1b4e19a.html [https://perma.cc/6LYM-WXDT]

537. United States v. Hoffman, No. MJ-17-0339-TUC-BGM, 2018 WL 2464115, at *3 (D. Ariz. June 1, 2018) ("Defendants' proclaimed moral, ethical, and spiritual belief to assist humans in need of basic necessities appears to be a simple recitation 'for the purpose of draping religious garb over [political or philosophical] activity." (alteration in original) (quoting United States v. Christie, 825 F.3d 1048, 1056 (9th Cir. 2016))).

538. Id. 
justice in other, legal ways. ${ }^{539}$ Indeed, DOJ attorneys in Hoffman had argued, "There are many methods for providing aid in the [refuge], some of which do not violate the rules and regulations, and the defendants' preference for one method over another cannot create a substantial burden." $" 540$

In overturning the magistrate judge, the federal district court in Hoffman found that the volunteers were indeed engaged in religious exercise. ${ }^{54}$ Like the Kelly court, the Hoffman court rejected the magistrate judge's finding of no substantial burden under RFRA. ${ }^{542}$ But unlike Kelly, the Hoffman court reversed the volunteers' convictions: the government failed to make its showing under the compelling interest and least restrictive alternative prongs of RFRA. ${ }^{543}$ As to the significance of alternatives, the court rejected the DOJ's argument that the volunteers had "other locations available for them to place their cache of supplies." 544

The impact of the RFRA analysis in Kelly and Hoffman in other contexts remains to be seen. Other groups venture onto public property to exercise their faith, but often without much protection unless they can invoke constitutional protections for expressive rights. ${ }^{545}$ Activists recently filed a complaint challenging Houston's anti-food-sharing law, which made it illegal to serve meals on public or private property to more than five homeless people without consent. ${ }^{546}$ The organization known as Food Not Bombs engages in peaceful political action to spread its message that poverty and hunger can be eliminated by redirecting

539. In an amicus brief filed by law professors in the appeal of the convictions of Hoffman and the three other volunteers, done through the Columbia Law School Law Rights, and Religion Project, the law professors noted "[i]t is possible" the magistrate judge rejected the substantial burden argument for this reason. Brief of and by Professors of Religious Liberty as Amici Curiae in Support of Neither Party on Defendants' Motion to Dismiss Under the Religious Freedom Restoration Act at 14, United States v. Hoffman, No. 4:19-CR-00693-RM (D. Ariz. Apr. 22, 2019), https://academiccommons.columbia.edu/doi/10.7916/d8-8bvg-ct09 [https://perma.cc/AN77-PFZD].

540. (Proposed) Brief of and by Professors of Religious Liberty as Amici Curiae in Support of Neither Party on Defendants' Motion to Dismiss Under the Religious Freedom Restoration Act at 15, United States v. Hoffman, 2018 WL 6831966 (D. Ariz. Dec. 28, 2018) (No. 17-00339MJ-TUCBGM), 2018 WL 7503835.

541. United States v. Hoffman, No. CR1900693001TUCRM, 2020 WL 531943, at*1 (D. Ariz. Feb. 3, 2020).

542. Id. at $* 8-10$.

543. Id. at $* 11-12$.

544. Id. at $* 9$.

545. See, e.g., Fort Lauderdale Food Not Bombs v. City of Fort Lauderdale, 901 F.3d 1235 (11th Cir. 2018) (holding food sharing was expressive conduct protected by the First Amendment).

546. Complaint at 3, Houston Food Not Bombs v. City of Houston, No. 4:19CV01661 (S.D. Tex. May 6, 2019). 
military spending. ${ }^{547}$ One of its members, Ailene Adams, is a Christian with "a sincere religious belief that sharing, receiving and giving food to others . . . is part of what her religion encourages her to do." 548 Citing to numerous passages of the Bible, Ms. Adams claims that the anti-sharing law infringes on her "deeply held belief as a Christian" to share food with more than five persons at a time outdoors without first seeking municipal permission. ${ }^{549}$ The outcome remains unclear even given the explicit reliance on the religious nature, and not merely the expressive nature, of the conduct. ${ }^{550}$

\section{CONCLUSION}

When religious progressives challenge laws, they also challenge the entrenched and polarized narratives of religious conservatives and secular liberals. Some of the current litigants may even challenge the more restrained free exercise approach of many religious liberals. They show us that religious freedom is broader than the protection of conservative causes and reveal the current administration's grand commitment to broad religious liberty as a commitment primarily to conservative causes.

This Article observed that while religious exercise is capable of generating conflicts that span the partisan divide, most present-day conservative religious claims take the form of refusals to comply with law, while most liberal religious claims are affirmative - that is, more fluid, indeterminate, contextualized, and discretionary. For such claims, it may be difficult to establish a substantial burden to one's free exercise either because coercion is lacking or alternative ways of exercising religion exist, or because religious exercise takes place on public property. These observations are not intended to suggest that religious liberals should organize to out-compete conservatives. Instead, this Article observes that the presence of progressive litigants now in the free exercise space begins to challenge the entrenched conservative and liberal narratives regarding the meaning and scope of religious freedom and offers a different set of moral concerns for public discourse. It challenges the narrow conception of rule-based religion with claims that

547. Id. at 15 .

548. Id. at 6.

549. Id. at 17 .

550. Compare Chosen 300 Ministries, Inc. v. City of Philadelphia, No. 12-3159, 2012 WL 3235317 (E.D. Pa. Aug. 9, 2012), with Santa Monica Food Not Bombs v. City of Santa Monica, 450 F.3d 1022 (9th Cir. 2006). 
often involve religious indeterminacy. It reminds us that progressives, like traditionalists, can find themselves out of step with majority norms and dependent upon the continued salience and endurance of private institutional and associational freedoms. It forces a reconsideration of the notion of complicity, which has been tied so closely to the conservative narrative. For these reasons, progressive religious claimants can contribute significantly to an ever-evolving political and juridical compromise among multiple religious freedom narratives. 